Andrews University

Digital Commons @ Andrews University

1999

\title{
Adventist Information Ministry: Historical-Missiological Foundations and an Evaluation of the Chaplain's Role
}

Gregory A. Harper

Andrews University

Follow this and additional works at: https://digitalcommons.andrews.edu/dmin

Part of the Practical Theology Commons

\section{Recommended Citation}

Harper, Gregory A., "Adventist Information Ministry: Historical-Missiological Foundations and an Evaluation of the Chaplain's Role" (1999). Professional Dissertations DMin. 648.

https://dx.doi.org/10.32597/dmin/648

https://digitalcommons.andrews.edu/dmin/648

This Project Report is brought to you for free and open access by the Graduate Research at Digital Commons @ Andrews University. It has been accepted for inclusion in Professional Dissertations DMin by an authorized administrator of Digital Commons @ Andrews University. For more information, please contact repository@andrews.edu. 


\section{ABSTRACT}

ADVENTIST INFORMATION MINISTRY: HISTORICALMISSIOLOGICAL FOUNDATIONS AND AN EVALUATION OF THE

CHAPLAIN'S ROLE

by

Gregory A. Harper

Adviser: Benjamin D. Schoun 


\author{
ABSTRACT OF GRADUATE STUDENT RESEARCH \\ Dissertation \\ Andrews University \\ Seventh-day Adventist Theological Seminary
}

Title: ADVENTIST INFORMATION MINISTRY: HISTORICALMISSIOLOGICAL FOUNDATIONS AND AN EVALUATION OF THE CHAPLAIN'S ROLE

Name of researcher: Gregory A. Harper

Name and degree of faculty adviser: Benjamin D. Schoun, D.Min.

Date completed: April 1999

Purpose

The aim of this dissertation was to: (1)

investigate and record historical and missiological

foundations of Adventist Information Ministry; (2) survey, analyze, describe, and evaluate perceptions about the AIM chaplain's role and present resulting recommendations; and (3) provide summaries and conclusions for the major topics and methodology revealed in the main body of this report.

\title{
Method
}

Following an investigation of historical documents, a qualitative survey based on Dillman's "Total 
Design Method" was implemented with six different groups of individuals associated with Adventist Information Ministry. Recorded input from sixty-five telephone interviews was analyzed and described according to pertinent group perceptions regarding the principle subjects of the study. The historical probes and phone interview findings were augmented with observations from the author's two and a half years of work experience as senior chaplain at Adventist Information Ministry.

\section{Results}

A treatise of trends spanning a fifteen-year period of time leading up to the birth of Adventist Information Ministry is now available under one cover. The display of documented contributions reveals that a host of foundational proclamations, formative ideas, technological inventions, and key institutions were involved. For the Adventist Information Ministry chaplain, six fundamental functions are ranked according to survey results for the importance and time spent for each function. Discoveries among the chaplain interviewees includes intercession receiving the place of greatest importance but least time spent, administration voted least important but second in time spent, and counseling looked upon with lower importance but claiming the most time spent. 


\section{Conclusions}

The variety of foundational sources made clear the delivery of Adventist Information Ministry was not the result of any one human being's work. It was concluded that the governing source behind these multiple developmental factors was the working of God through His Holy spirit. Given the blend of widely differing perspectives pertaining to the counseling component of the chaplain's role, a concluding recommendation was directed to current leadership, staff, and chaplains at Adventist Information Ministry to meet together and work through the likelihood of ongoing misunderstandings in this important area. 
Andrews University

Seventh-day Adventist Theological Seminary

ADVENTIST INFORMATION MINISTRY: HISTORICALMISSIOLOGICAL FOUNDATIONS AND

AN EVALUATION OF THE

CHAPLAIN'S ROLE

\author{
A Dissertation \\ Presented in Partial Fulfillment \\ of the Requirements for the Degree \\ Doctor of Ministry
}

by

Gregory A. Harper

April 1999 


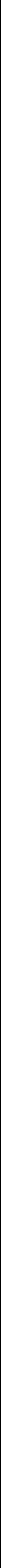




\section{ADVENTIST INFORMATION MINISTRY: HISTORICAL- MISSIOLOGICAL FOUNDATIONS AND \\ AN EVALUATION OF THE \\ CHAPLAIN'S ROLE}

\section{A dissertation}

presented in partial fulfillment

of the requirements for the degree

Doctor of Ministry

by

Gregory A. Harper

APPROVAL BY THE COMMITTEE:
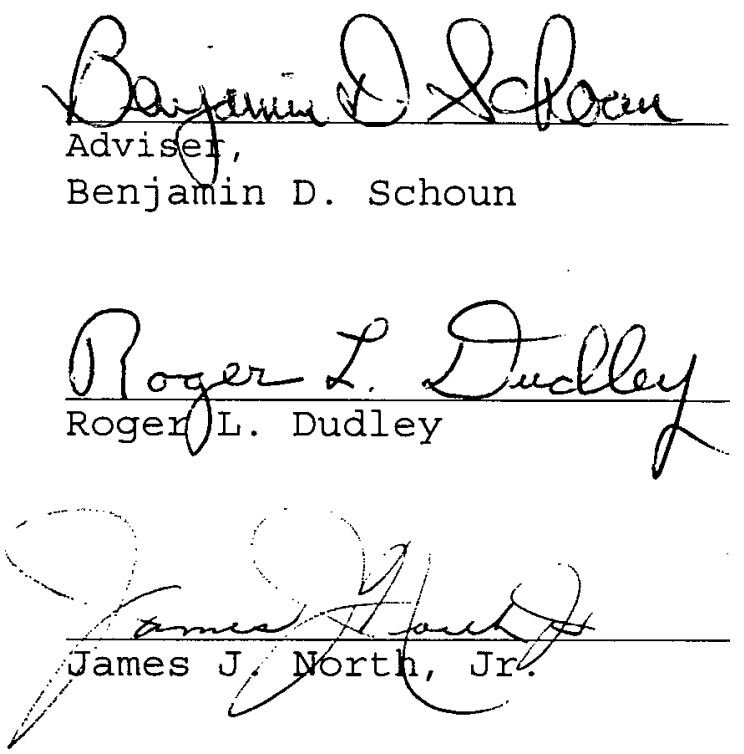

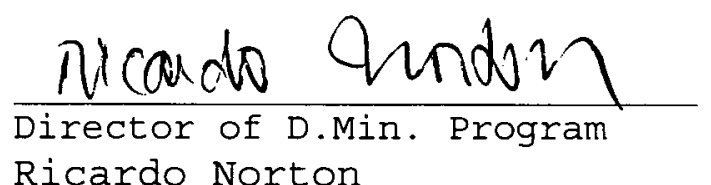

Ricardo Norton

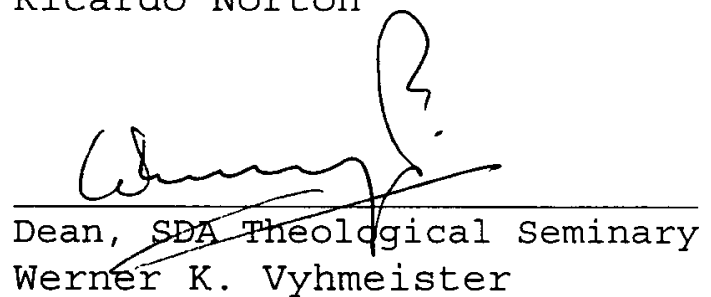

Atin 14,1999 
TABLE OF CONTENTS

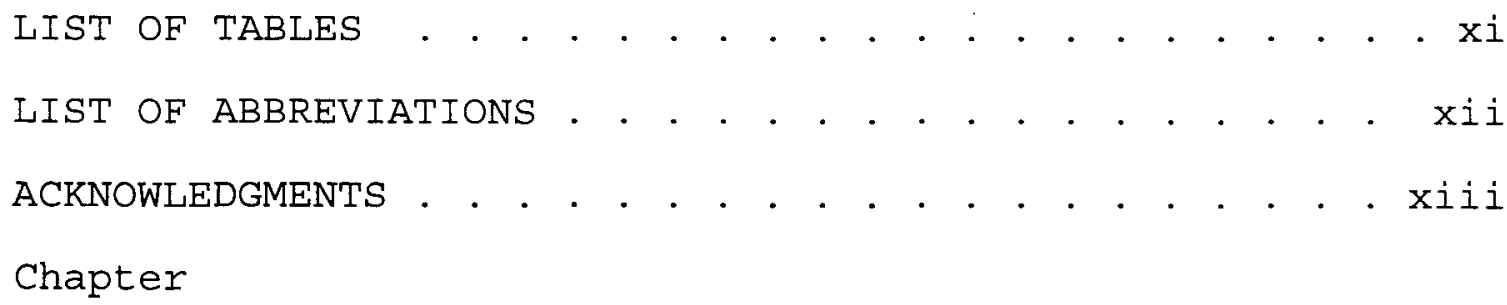

1. INTRODUCTION . . . . . . . . . . . . . . . . . . . 1

Purpose . . . . . . . . . . . . . . . . . . . . 1

Justification . . . . . . . . . . . . . . . . . . 1

Revisiting AIM's Roots . . . . . . . . . . 1

Interviewing AIM's Travelers . . . . . . . . 3

Pondering AIM Chaplain's Pathways . . . . . . 4

Development . . . . . . . . . . . . . . . 5

In the Beginning . . . . . . . . . . . . . 5

Searching for Foundations . . . . . . . . . 5

Developing and Conducting a Suitable Survey . 8

Preview . . . . . . . . . . . . . . . . . 9

Delimitations . . . . . . . . . . . . . . . . . 11

A Descriptive study . . . . . . . . . . . . . 11

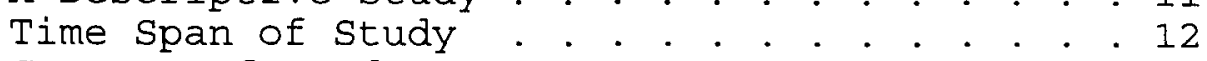

Content of Study . . . . . . . . . . . . 12

Expectations . . . . . . . . . . . . . . . . . . 14

SDA Church Mission and Media Evangelism. . . 14

NAD Members and Leadership . . . . . . . . 14

AIM Founders and Chaplains . . . . . . . . 15

AIM Employees and Leadership . . . . . . . 16

2. INTERVIEWS . . . . . . . . . . . . . . . . . . . . 17

Dillman's Methodology Chosen . . . . . . . . . 17

Philosophy of the Total Design Method . . . . . 18

What Influenced the Total Design Method's

Conception . . . . . . . . . . . . . . 18

Affecting Response . . . . . . . . . . . 19

Survey Organization. . . . . . . . . . . . 20

A Mail Survey or Telephone Interview? . . . . . 21

Considering Survey Characteristics . . . . . 22

Special Characteristics . . . . . . . . . . 24

Constructing the Telephone Interview . . . . . . 24

Respondents' Needs . . . . . . . . . . 25 
First Questions . . . . . . . . . . . . 26

Never Seen but Heard . . . . . . . . . . 27

Organization and Objectives of the

Interview Instrument . . . . . . . . . . . 27

Completed Questionnaires . . . . . . . . 30

The Pilot Phone Interview . . . . . . . . . 30

In Principle . . . . . . . . . . . . . . . 30

In Practice. . . . . . . . . . . . . . . . . 31

Electronic Recording Problems and a

Decision to Move Ahead . . . . . . . . . . 32

Conducting the Phone Interviews . . . . . . . 34

Sample Selection: Who and How Many? . . . . 34

AIM founders. . . . . . . . . . . . . 34

AIM chaplains . . . . . . . . . . . . . . 35

AIM steering committee members . . . . . 35

AIM staff . . . . . . . . . . . . . . . 35

Agencies . . . . . . . . . . . . . 36

Pastors . . . . . . . . . . . . . . . . . 36

Agencies and pastors combined . . . . . 36

Interview Questions Asked and Question

Flexibility . . . . . . . . . . . . . . 37

Additional Electronic Recording Problems . . 38

Summary of Phone Interview Statistics . . . . 40

By group . . . . . . . . . . . . 40

Totals . . . . . . . . . . . . . . . 41

3. FOUNDATIONS . . . . . . . . . . . . . . . . . . 43

Some Missiological Foundations . . . . . . . . 43

Christ's Great Commission . . . . . . . . . . 43

Ellen White on Evangelism . . . . . . . . . . 44

No greater work . . . . . . . . . . . . . 44

Ministerial priorities and the value

of the soul... . . . . . . . . . . 45

The importance of evangelistic follow-up . 45

slackness in follow-up makes angels weep . 47

Evangelism: Heartbeat of Christianity and

the SDA Church............. . . 47

Annual Council's call for successful

follow-up methods in 1976 . . . . . . 48

NAD evangelism outlook in the early $1980 \mathrm{~s}$. . . . . . . . . . . . . . 49

Giving unquestioned priority to SDA evangelism in 1981 . . . . . . . . . . . 50

A letter from the General Conference President in 1982 . . . . . . . . . . . 51

Some Foundational Tools . . . . . . . . . . . . 52

1967: Telephone Evangelism . . . . . . . . . 52

1972: Database Plan Proposed . . . . . . . 53

1976-1982: Combining Literature Evangelism

and the Telephone . . . . . . . . . . . 53

1976-1979: NAD Tools Committee . . . . . . . 54 
1980s: The Tool of the Decade... . . . . . 56

Linking Two Technological Tools . . . . . . . 57

Some Institutional Foundations . . . . . . . . . 57

Institute of Church Ministry . . . . . . . . 57

Blending ministry-minded research

with technology . . . . . . . . . 58

Wide-ranging operations . . . . . . . . 59

ICM's Key Contributions toward AIM's

Conception . . . . . . . . . . . . . . . 60

Research studies and telephone services . 60

Des Cummings' Jr.'s burden for practical seminary training. . . . . . . . . . . 60

Consultation services for SDA media

telecasts............. . 62

A pivotal question . . . . . . . . . . 63

Computing Center Contributions . . . . . . 64

Bob Moon . . . . . . . . . . . . . . 64

Lowell Witz . . . . . . . . . . . . 64

Technical help and equipment. . . . . . 65

The Birth of Adventist Information Service

and Adventist Information Ministry . . . . . 66

Institute of Church Ministry's Toll-Free

Telephones Pilot Project . . . . . . . 66

ICM's Visionary 800-Number Proposal to

It Is Written . . . . . . . . . . . . . 67

Proposal overview . . . . . . . . . . . . 67

Andrews University's unique capabilities

identified . . . . . . . . . . . . 68

Proposal accepted by George Vandeman and

the IIW board.. . . . . . . . . . . . 69

Broader 800-Number Plan Presented to the

General Conference of SDAs... . . . 70

NAD Leadership Support . . . . . . . . . 71

Charles Bradford . . . . . . . . . . . . 71

Robert Dale and the AIM name target . . 71

GC and union detractors silenced by

AIM cheering squad . . . . . . . . 72

A Basement Building Beginning with World's

Fair Prominence in 1982 . . . . . . . . . 73

Publication of Early Developments . . . . . . 75

Adventist Information Service. . . . . . . . 75

A new telephone ministry . . . . . . . . . 75

A result of studies conducted by ICM . . . 75

Initial GC funding brings a twofold

benefit. . . . . . . . . . . . 76

Doug Tilstra's look at AIS's system

of evaluation and follow-up... . . . 77

Three-step follow-up approach of

A.I.S. chaplains . . . . . . . . . . 78

A helpful name change . . . . . . . . . . 79

Adventist Information Ministry . . . . . . . 80

Twelve 800-number lines . . . . . . . 80 
Expansion while the phones keep ringing . 81

A staff picture for the nation-wide phone ministry . . . . . . . . . . . . 81

One year old and already a major resource center. . . . . . . . . . 83

Craig Willis looked back at a bright future... . . . . . . . 84

4. CHAPLAINS . . . . . . . . . . . . . . . 85

Development of the A.I.S./AIM Chaplain:

Some Historical Perspective... . . . . . 85

The Chaplain's Name... . . . . . . . . 85

Seminary students selected to serve

for the Developing Role . . . . . . . . 87

Setting Initial objectives . . . . . . . . 88

Description of the AIM Chaplain's Role:

A More Recent Perspective . . . . . . . . . . 89

AIM Chaplain's Fundamental Responsibilities . 90

AIM Chaplain's Unilateral Responsibilities . 92

Letter-writing chaplain and bilingual

chaplain . . . . . . . . . . . . 92

The senior chaplain . . . . . . . . . . . 93

Perceptions about the AIM Chaplain's Role:

Interview Response Analysis and

Evaluations... . . . . . . . . . . . . . 93

Job Training, Chaplain's Manual,

Accountability, and Evaluation . . . . . 94

Question 16: Chaplains' evaluation of job training . . . . . . . . . . . . . 94

Question 16: AIM staff viewpoint. . . . 96

Question 17: Chaplains' perspective on a chaplain's manual . . . . . . . . 97

Question 17: Staff response . . . . . . . 99

Question 18: Chaplains' comments on accountability . . . . . . . . . . . 99

Question 18: Staff response . . . . . . 102

Question 18: Steering committee reply . 103

Question 19: Evaluation within the

chaplain's department....... . 104

Perceptions about the Senior Chaplain's

Role

Question 32: Chaplains' perspective $\cdot 105$

Question 32: Committee and staff

perspective. . . . . . . . . . . . 106

Question 33: Chaplains' perspective on

improving the senior chaplain's role 107

Question 33: Staff's perspective . . . 110

Questions 24 and 26: Chaplains' Ranking

of Their Fundamental Functions. . . . . 110

Table 6 introduction. . . . . . . . . . 111

Table 6 overview . . . . . . . . . . . . 112 
Analysis of findings . . . . . . . . . 113

Administration . . . . . . . . . . . . . . 114

A constant juggling with six important responsibilities . . . . . . . . . 114

Question 30: Improving the AIM chaplain's role of administration . . 114

Question 27: Time-management adjustments . . . . . . . . . . . 115

Meetings

Question 21: Weaknesses of chaplains' meetings . . . . . . . . . . . . . . 117

Question 2I: Strengths of chaplains' meetings . . . . . . . . . . . . 119

Counseling . . . . . . . . . . . . . . . . 122

How the phrase "counselor" and its alternatives were viewed . . . . . 122

Question 20: Executive steering committee views........ . . . 124

Question 20: Staff viewpoint. . . . . 125

Referral and Follow-Up . . . . . . . . . . 126

Question 31: Significant contributions of the AIM chaplain . . . . . . . . . 127

Question 30: Improvements suggested . . 128

Intercession . . . . . . . . . . . . . . . 129

Question 22: Staff and committee response . . . . . . . . . . . 130

Question 22: Chaplains' reply . . . . . 132

Chaplains' ideas for improving AIM's prayer ministry . . . . . . . . . . . 133

Timing: When should intercession occur at AIM? . . . . . . . . . . . . . .

Manner: How should AIM prayer requests be handled?..... . . . . . . . . . 135

Personnel: Who should be interceding at AIM? . . . . . . . . . . . . 136

Questions 24 and 25: Committee, Founders, and staff Ranking of the AIM Chaplains'

Fundamental Responsibilities . . . . . . 138

Question 24: Ranking the chaplains'
fundamental functions . . . . . . 138

Question 25: Reasons for rankings
revealed in table 7. . . . . . . . 140

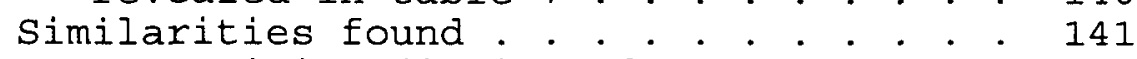

Two surprising findings from table 7 . 142

5. SUMMARIES, RECOMMENDATIONS, AND CONCLUSIONS . . 144

Introduction. . . . . . . . . . . . . . . 144

Summary of Chapter 4.............. . . 145

Conclusions: The AIM Chaplain's Role. . . . 146

The Introductory $29^{\text {th }}$ Question . . . . . 146 
Meetings . . . . . . . . . . . . . . . . .

Recommendation: Use Voice Mail and in-house E-mail to its fullest advantages . . . . . . . . .

Recommendation: Periodicaliy poll current chaplain teams to identify weaknesses and make adjustments as necessary . . . . . . . . . . . 148

Administration . . . . . . . . . . . . . . 149

Recommendation: Employ a chaplain's secretary with regularity. . . . . 149

Recommendation: Follow-up on fully functioning chaplains' computers independent of Andrews University . . 150

Recommendation: Adopt spiritual giftsbased assigning of chaplain's fundamental functions . . . . . . . . 152 Intercession . . . . . . . . . . . . . . . 152

A confusing correlation . . . . . . . 153

A parallel observation and recommendation for further study . . 153

Recommendation: Implement interviewed chaplains' strategies for improving AIM's prayer ministry . . . . . . . . 154

Referral and Follow-Up . . . . . . . . . 155

Are referral and follow-up the bull's eye of the AIM chaplain's target? . . 156

Recommendation: Fire with a definite aim at the bull's eye worthy of the AIM target . . . . . . . . . . . 159

Counseling . . . . . . . . . . . . . . . . 160

Recommendation 1: Understand the basic counseling qualities needed for chaplains at AIM . . . . . . . . . . 161

Recommendation 2: Trust in the protection provided by the simple disclaimer statement . . . 162

Recommendation 3: Refer to counseling at AIM by the name "pastoral counseling"

Recommendation 4: Further training desired and questioned with pragmatic alternatives suggested . . 164

Recommendation 5: Adopt verbatim-based practicums with regularity in chaplains' meetings . . . . . . . 166

Recommendation 6: Remember the spiritual-gifts approach . . . . . 166

Recommendation 7: Hiring
considerations . . . . . . . 167

Recommendation 8: Greater availability for taking calls, and pagers needed. 
Recommendation 9: Cautions regarding regular callers and caller ID suggested . . . . . . . . . . . 169

Recommendation 10: Work through the likelihood of ongoing misunderstandings with chaplains' counseling at AIM

Question 28: Considering the AIM

Chaplains' Contributions . . . . . . . . 171

Chaplains' fundamental functions validated

Areas chosen for recommendations confirmed

Additional findings and dissertation limitations............ . . 173

A confession about upgrading . . . . . . 174

Summary of Chapter 3..... . . . . . . . 175

Conclusions: AIM's Foundations . . . . . . . . 176

A Variety of Foundational Sources . . . . . 176

No Single Human Being Should Be Thought of as the Founder

The Untold Story: God's Hand Guided the

Overall Plan... . . . . . . . . . . . 178

God at the Switchboard . . . . . . . . . 178

Summary of Chapter 2. . . . . . . . . . . . . 181

Conclusions: The Pilot Phone Interview and

the Interview Instrument

The Pilot Phone Interview: Pretests Were Needed With People Not Working at AIM

An Assortment of Questions Outside

Stated Scope of Dissertation

What a Redesigned Interview Instrument Would Change . . . . . . . . . . . . 183

Perceived Benefits from a Revamped Interview Instrument . . . . . . . . . 185

Questioning Whether a Redesigned

Instrument Would Have Helped

Certain Interviewees . . . . . . . . . . 186

A Final Conclusion: Jer 6:16 and Rest . . . . I88

Appendix

A. ADVENTIST INFORMATION MINISTRY OVERVIEW:

AN EARLY 1990S PERSPECTIVE . . . . .

B. PRELIMINARY PROPOSAL TO IT IS WRITTEN BY

ANDREWS UNIVERSITY TO PROVIDE LISTENER

REQUEST PROCESSING, INTEREST FOLLOW-UP,

AND DONATION PROCESSING SERVICES.

C. SATISFACTION WITH RELATED SERVICES AT

ADVENTIST INFORMATION MINISTRY . . . . . . . . 206

D. INTERVIEW INSTRUMENT . . . . . . . . . . . . . . 215 
E. PHONE LOG . . . . . . . . . . . . . . . . . . . . 225

F. EXAMPLE: ADVENTIST INFORMATION SERVICE AND

ADVENTIST INFORMATION MINISTRY LETTERHEADS . . 238

G. THE AIM CHAPLAIN'S DISCLAIMER STATEMENT . . . . . 241

H. AIM STEERING COMMITTEE MEETING ATTENDANCE . . . . . 243

BIBLIOGRAPHY . . . . . . . . . . . . . . . . . . . 246

VITA . . . . . . . . . . . . . . . . . . . . . . . 251 


\section{LIST OF TABLES}

1. Encouraging Response for Potential Survey

Respondents . . . . . . . . . . . . . . 20

2. Rating of Mail Questionnaires and Telephone

Interviews For Selected Performance

Characteristics. . . . . . . . . . . . 23

3. Summarization of Pilot Phone Interview

Debriefing . . . . . . . . . . . . . 33

4. Telephone Interview Statistics . . . . . . . . . 42

5. Fundamental Responsibilities of the AIM

Chaplain . . . . . . . . . . . . . . . 91

6. Ranking of Chaplains' Functions by Importance and Time Spent: AIM Chaplains' Response . . . 112

7. Ranking of Chaplains' Functions by Importance:

AIM Committee/Founders and AIM

Staff Response 


\section{LIST OF ABBREVIATIONS}

AIM Adventist Information Ministry

A.I.S. Adventist Information Services

FAA Faith Action Advance

GC General Conference

ICM Institute of Church Ministry

IIW It Is Written

M.Div. Master of Divinity

NAD North American Division

NADEI North American Division Evangelism Institute

NASB New American Standard Bible

NIV New International Version

SDA Seventh-day Adventist

TDM Total Design Method 


\section{ACKNOWLEDGMENTS}

For topnotch advisers and benevolent employers, for supportive family and praying friends,

for God's amazing grace and guidance, I offer thanks and say amen. 


\section{CHAPTER ONE}

\section{INTRODUCTION}

\section{Purpose}

This dissertation focuses on Adventist Information Ministry, also known as AIM. ${ }^{1}$ As this Doctor of Ministry research project has unfolded and matured, a threefold purpose has developed. It is the aim of this report to: (1) investigate and record historical and missiological foundations of Adventist Information Ministry; (2) survey, analyze, describe, and evaluate perceptions about the AIM chaplain's role and present resulting recommendations; and (3) provide summaries and conclusions for the major topics and methodology revealed in the main body of this study.

\section{Justification}

\section{Revisiting AIM's Roots}

More than two and a half millenniums ago, the old Testament prophet Jeremiah penned these thought-provoking words to God's people:

${ }^{1} \mathrm{AIM}$ is a multi-faceted non-profit organization that principally functions as an evangelistically-oriented telephone answering service and follow-up ministry on behalf of the seventh-day Adventist Church. For a more detailed description of Adventist Information Ministry from an early 1990 s perspective see Appendix A. 
This is what the Lord says: Stand at the crossroads and look; ask for the ancient paths, ask where the good way is, and walk in it, and you will find rest for your souls. (Jer 6:16, NIV)

The author of this dissertation perceives in the Jer 6:16 summons a Bible-based justification for undertaking the chief components selected for this study of Adventist Information Ministry as succinctly described in the statement of purpose.

In harmony with the Lord's counsel for His ancient followers to "stand" and "look" back over the pathways of their journey, present-day Bible-believers still believe it is fitting to consider the pathways of the past which have brought them to where they now stand. ${ }^{1}$ To the author's knowledge, a treatise of trends leading up to AIM's beginning has not been documented in any form. Apart from bits and pieces told primarily through various periodical articles, an overview of Adventist Information Ministry's origins and early development has simply not been available under one cover. With the chronicling of AIM's founding as

${ }^{1}$ For Seventh-day Adventists the following words are well ingrained: "We have nothing to fear for the future, except as we forget the way the Lord has led us, and His teaching in our past history." Ellen White, Life Sketches (Mountain View, CA: Pacific Press Publishing, 1915), 196.

Ellen White was one of the founders of the Seventh-day Adventist Church. "Although many of her writings are directed to the Seventh-day Adventist Church, large portions have been appreciated by wider audiences. Her popular book steps to Christ has been translated into more than 100 languages and has sold more than 15 million copies." Seventh-day Adventists Believe: A Biblical Exposition of 27 Fundamental Doctrines (Hagerstown, MD: Ministerial Association, General Conference of Seventh-day Adventists, 1988), 226. 
set forth in this dissertation, it will be possible for others who have an interest in Adventist Information Ministry to view an accessible and substantial record of AIM's roots up through its first year of operant ministry.

\section{Interviewing AIM's Travelers}

Rather than rely on their own knowledge and wisdom, the travelers in the Jer $6: 16$ passage were encouraged to "ask" about the ancient paths which converged at the crossroads. In order to rightly discern these time-honored passageways, the pilgrims evidently needed to make inquiry among other individuals who had experience along the pathways being considered. Regardless of the background these voyagers may have already had in walking these roads, the invitation to ask indicates they needed insights from knowledgeable others to truly find the way.

Similarly, while the author brings two and a half years of personal experience as senior chaplain at AIM to this research undertaking, it would be impossible from that backdrop alone to adequately tell the story of AIM's foundational history or suitably report on the role of its chaplains. Probing others about AIM's heritage and first dozen years of ministry through a survey given to those who helped establish AIM's roads and have walked its paths was deemed essential. Thus a basis emerged for conducting interviews with enlightened individuals to gather the range of input needed for this research report. 
Pondering AIM Chaplain's Pathways

In tracing the progression of counsel found in Jer 6:16, the reader discovers that once a query into the former pathways occurred, an inquiry about "the good way" was to follow. By inviting travelers to ask where the best route lay, it stands to reason from the context of Jeremiah's sixth chapter that God wanted his sojourners to not repeat the mistakes of the past but to learn from these figurative roadways of old and obtain from them dependable and beneficial information for upcoming travel through life.

Though many centuries have transpired since Jeremiah spoke, the wisdom set forth in his words seems even more applicable to the ever-expanding information age and rapidly changing global market we live in today. The competitive demands of the $1990 \mathrm{~s}$ compel even not-for-profit ministries to periodically pursue purposeful review and reassess their place in the surrounding marketplace in order to more effectively serve their clientele and operate efficiently in the process.

This report therefore offers something more than a convenient place to locate a story of AIM's roots and recapitulate functions of the AIM chaplain. Like the metaphoric traveler in the Jer 6:16 passage of Scripture,

1 "The metaphor is that of a traveler who, having lost his way, stations himself at the juncture of several different roads, carefully considering and diligently inquiring after the right one." "stand ye in the Ways" [Jer 6:16], Seventh-day Adventist Bible Commentary (SDABC), ed. F. D. Nichol (Washington, DC: Review and Herald, 1976), 4:383. 
the author has sought to carefully examine and assess the collective array of interviewee input regarding AIM's past and more recent present for the ultimate purpose of helping AIM chaplains "walk" more fully in their awesome task of helping "souls" arrive into God's heavenly kingdom.

\section{Development}

In the Beginning

Dialog about this dissertation began in the fall of 1993 and was interspersed with periodic meetings through the summer of 1994 with the dissertation adviser, Benjamin Schoun. Discussions revolving around the dissertation topic also occurred with the director of AIM, Robert Moon; the associate director/follow-up coordinator of AIM, Craig Willis; and the AIM business/operations manager, John Hood. The gathering of research material started with locating unpublished documents applicable to the role of AIM chaplains on file in the AIM follow-up coordinator's office, the AIM chaplain's booths, and the AIM secretary's files. These departments are all housed in the main office of Adventist Information Ministry, which is located in the Information Services Building on the campus of Andrews University in Berrien Springs, Michigan.

\section{Searching for Foundations}

The search for documentation on the early history of Adventist Information Ministry also commenced at the AIM 
office. A sampling of the initial correspondence and statistics generated by early AIM workers, found in old files from the AIM office storeroom, told a fraction of the story. A slide presentation produced in 1987 titled "THE PERSONAL TOUCH of Adventist Information Ministry" ${ }^{1}$ narrated the story of AIM operations up to that time in a capsulized visual format, offering a fleeting reference to the founding of AIM. The pamphlets AIM had printed for advertising its services spoke briefly about its history. This was the extent of available materials discovered from the office of Adventist Information Ministry regarding AIM's roots.

The investigation for historical documents moved to the AIM director's office in the Administration Building at Andrews University. It was here that a notebook containing the minutes for ten years of meetings by a committee giving guidance to AIM was discovered. This guidance group, known as the AIM Executive steering Committee, was not officially started until two and a half years after AIM began its services. The comments found in these minutes were very brief records of business and operational items that had been voted on.

Searching for historic material progressed to the James White Library at Andrews University and the 1981 through 1993 volumes of the Seventh-day Adventist Periodical

1"THE PERSONAL TOUCH of Adventist Information Ministry," Slide and Cassette Tape Presentation (Decatur, GA: Photo Sound International, 1987). 
Index, ${ }^{1}$ which yielded a listing of twenty-six articles on AIM. These contained a number of references to Adventist Information Ministry's foundations, particularly the periodical articles from the 1982 and 1983 years of publication. The Andrews University Focus, ${ }^{2}$ which was not registered in the above index, was examined page by page from the 1981 through 1993 publication years, resulting in two articles, one letter to the editor, and one brief mention of AIM. A probe into the Institute of Church Ministry's issues of Administry $^{3}$ bestowed two articles directly related to the early seasons of what was then referred to as Adventist Information Service.

A small folder surprisingly surfaced in April of 1994, a few weeks after the major search for source materials on the Andrews Campus had concluded. The folder, from an unknown source in the Administration building at Andrews University, was passed on to the AIM director, who in turn donated its contents to this dissertation project. The folder contained a small stack of computer-fold paper with penciled notes on top of typed text bordered by ragged

${ }^{1}$ Gina Boyd, Harvey Brenneise, and Daniel Drazen, eds., Seventhday Adventist Periodical Index, 13 vols. (Berrien Springs, MI: Andrews University Press, 1981-1993).

${ }^{2}$ Focus, vols. 16-29 (Berrien Springs, MI: Andrews University Public Relations Office, 1980-1993).

${ }^{3}$ Roger Dudley, ed., Administry, a joint publication of The Institute of Church Ministry and The North American Division of Seventhday Adventists, Autumn 1982 and Autumn 1983. 
edges that looked as though it belonged in the wastebasket. A more careful scrutiny of the folder's contents revealed an interesting find for the historical aspect of this research. These papers contained the preliminary draft of an undated but very detailed "Proposal to 'It Is Written' by Andrews University to Provide Listener Request Processing, Interest Follow-Up, and Donation Processing Services" (see Appendix B for a tidier and more detailed version later sent to the author). Though in an unfinished form with "preliminary" scribbled on the top of the first page, this document revealed intricacies of a ministry that was conceptually well developed prior to the published beginnings of AIM.

While the sum of these collected materials contained many helpful references to Adventist Information Ministry's beginnings, the story of how this organization came into being still seemed incomplete. It was recognized the only likely way to uncover a deeper understanding of the conception, birth, and early years of AIM's foundations and its chaplaincy movement was through enlisting and talking with individuals who had contributed to its founding and/or participated in its operational ministry.

Developing and Conducting a Suitable Survey

Counsel was sought from the Institute of Church Ministry at Andrews University to assist with the proper development of an interview instrument. It was the 
Institute's professional recommendation to consider Dillman's slightly dated but proven work, ${ }^{1}$ which was chosen following the review of a number of alternatives.

The advantages and disadvantages of conducting a survey through the mail versus an interview by phone were compared. For the purposes of this research project, it became clear that the benefits outweighed the limitations for utilizing the telephone interview method. ${ }^{2}$

In consultation with the author's dissertation advisor and the director of the Institute of Church Ministry, Roger Dudley, phone interviews were drafted in harmony with Dillman's "Total Design Method." Following a number of revisions to the survey instrument, a pilot phone interview preceded commencement of the telephone interview campaign. Close to 275 phone calls made by the author and a little over 25 calls returned to him resulted in the culmination of 65 completed phone interviews during the latter part of April and early May of 1994.

\section{Preview}

Writing commenced in mid-May and proceeded through mid-September of 1994 under the guidance of the author's

${ }^{1}$ Don Dillman, Mail and Telephone Surveys: The Total Design

Method (New York: John Wiley and Sons, 1978).

"Interviews with a purpose, an outline, and a recording system will give good information. They should be interesting as well. For in-depth information on opinions and attitudes, they are far superior to surveys." Nancy Jean Vyhmeister, Handbook for Research (Silang, Cavite, Republic of the Philippines: Ailas Publications, 1989), 94. 
dissertation committee, during which time the first three chapters were chiefly composed. With the input gleaned from the phone interviews offering a significant footing for much of this report, a delineation of survey details was believed to warrant its own chapter. Thus, following this first chapter's introduction to the dissertation, the process of developing and implementing the telephone interviews is described in detail in chapter 2. The undergirding nature of the interview information also planted a rationale for the placement of this second chapter in advance of AIM's foundations which are fully set forth in chapter 3 . The third chapter then identifies some missiological-based, tool-related and institutionally-situated foundations that contributed to the birth of AIM. Chapter 3 closes with a look at highlights from various publications which provided circulated press releases for the brand new ministry.

Chapter 4 unveils the development and description of the AIM chaplain based on surveyed perspectives and personal experiences. The author then introduces accumulated and appraised perceptions regarding the role of the Adventist Information Ministry chaplain. Continuing with and growing out of these multiple understandings, chapter 4 further offers interviewee's evaluations and suggestions for the AIM chaplain's fundamental responsibilities. In the fifth and final chapter a reader will find summaries, recommendations, and conclusions for each of the three preceding chapters, 
followed by a final conclusion to the dissertation. The fourth and fifth chapters were mostly constructed and completed during the later summer through early fall months of 1998 and winter months of 1999.

\section{Delimitations}

\section{A Descriptive study}

While this dissertation shares elements of a few different types of Doctor of Ministry research designs, it is most closely affiliated with the descriptive research model. This research paradigm has been concisely characterized as:

a study that describes the present and/or historical status of a generalized practice, and the effect of such practice. It would be expected that in such a project the information gathered would be used to evaluate present practice and make suggestions for improved practice.

Based on interview input and the author's work experience as senior chaplain at AIM, this dissertation offers suggestions and recommendations for the enhancement of services related to the AIM chaplain's work. However, due to the limited scope of this study and the confined length of its presentation, this report is not meant to serve as a type of a handbook for AIM chaplains or a model for future processes at Adventist Information Ministry.

${ }^{1} \mathrm{C}$. Raymond Holmes, Class handout for CHMN 790 Project Seminar, "Guidelines for the Doctor of Ministry Project, Project Proposal, and Project Report," SDA Theological Seminary, Andrews University, Berrien Springs, MI, July 1993, 4. 
Time Span of Study

"Descriptive research usually studies a situation at a given moment in time. A specialized type studies a person, case, or situation over time." ${ }^{1}$ The period of time traversed in this study of Adventist Information Ministry begins approximately fifteen years in advance of AIM's official beginning, with a glance at trends leading up to AIM's actual conception. The few years just prior to Adventist Information Ministry's birth plus the first year of its publicized service receive the bulk of historical coverage divulged in this document. The examination of the AIM chaplain's ministry reflects a time period of about a dozen years of functional history at Adventist Information Ministry, concluding in the summer of 1994.

\section{Content of study}

The collection of historical material dealing with AIM's early years is limited to what was previously described in this chapter under "Searching for Foundations," plus the response from the telephone interviews conducted with AIM founders. While an earnest attempt was made to report on this beginning period of AIM's history in a factual and chronological way, substantiating or validating every detail was not considered realistic or possible.

\footnotetext{
${ }^{1}$ Vyhmeister, 89.
} 
The interview instrument formulated and utilized for this dissertation was qualitative rather than quantitative in its design. ${ }^{1}$ A reader should not anticipate encountering a high level of statistical sophistication in the analysis of data from the interview survey or in the presentation of its results.

Reporting response from the interview questionnaire exhibits a targeted focus on the abundance of findings related to the AIM chaplain and to a lesser degree AIM's foundations. Brief attention is given to a few of AIM's other services performed in part by another group of student-based phone operators, which can be discovered in the appendices section of the dissertation (see Appendix C). Because the interview response to a host of survey questions directed to several AIM leadership roles was frequently minimal and very subjective, no reporting on that input has been pursued in this document. The combined limitations delineated in this delimitations section further prohibited the development of any realistic reportage within this dissertation for the role of the AIM follow-up coordinator, the AIM director and the AIM steering committee.

\footnotetext{
1 "Because of the depth and volume of information obtained in an interview, the number of persons interviewed is much smaller than the number of those surveyed. This kind of research is called qualitative research." Vyhmeister, Handbook for Research (1998 edition), 109.
} 


\section{Expectations}

SDA Church Mission and

Media Evangelism

It is true that Adventist Information Ministry is but one of many evangelistic entities within a massive church structure. Nevertheless, AIM still plays a unique and important role for the outreach wing of the seventh-day Adventist (SDA) Church. It is therefore believed that this dissertation will make a modest yet helpful contribution to the mission of this denomination.

Adventist Information Ministry serves at the crossroads for much of the SDA media evangelism traffic within the North American Division. To the extent that this report can benefit AIM and enhance its services in assisting the Adventist Media Center in its mission, the soul-winning work of the church may prosper.

$\underline{\text { NAD Members and Leadership }}$

Due to the North American Division's (NAD's) financial investment which provides approximately 50 percent of AIM's total operating budget, ${ }^{1}$ it is expected that this report will be of some value. Light will be indirectly shed on the use of this sacred money which is received from tithe-paying church members scattered throughout the North American Division. With the call to stewardship

\footnotetext{
${ }^{1} \mathrm{John}$ Hood, AIM Business/Operations Manager, interview by author, March 1994 .
} 
accountability as revealed in Scripture and the writings of Ellen White, ${ }^{2}$ NAD-based church members do have a vested interest in this project.

As the North American Division is the entity to which AIM is responsible, NAD leadership needs a periodic report of Adventist Information Ministry set before them. It is believed this dissertation can assist in serving for that purpose. This particular study should be meaningful to those NAD leaders who have attended an AIM Executive Steering Committee meeting (see Appendix H) and/or have some degree of acquaintance with AIM.

\section{$\underline{\text { AIM Founders and Chaplains }}$}

A small blessing is expected for each of the trailblazers who made pivotal donations to the founding and/or guiding of Adventist Information Ministry in its early stages. These individuals who invested a substantial portion of their time and talents in the development of AIM should find material in the foundations section of this

${ }^{1}$ The passage of scripture referred to by some as "The Unrighteous Steward" reads: "Now He [Jesus] was also saying to the disciples, 'There was a certain rich man who had a steward. . . . And he called him and said to him, "What is this I hear about you? Give an account of your stewardship" " (Luke 16:1-2 NASB).

"We should ever remember that in the judgment we must meet the record of the way we use God's money. . . . I was shown that the recording angel makes a faithful record of every offering dedicated to God and put into the treasury and also of the final result of the means thus bestowed. The eye of God takes cognizance of every farthing devoted to His cause." Ellen G. White, Adventist Home (Nashville, TN: Southern Publishing Association, 1952), 368. 
report that will affirm them for their pioneering role and potentially broaden their knowledge of the multifaceted means that God appears to have engineered to bring this ministry into reality.

Interviewee perceptions revolving around the role of the AIM chaplain should be of special interest to all former and current chaplains of Adventist Information Ministry, especially those who participated in the telephone survey. The integration and analysis of these multiple viewpoints will hopefully reveal important understandings and misunderstandings that should provide usable insights for the specific benefit of chaplains and their leadership whom are currently serving at AIM.

\section{AIM Employees and Leadership}

Nearing last but not least, it is believed this dissertation can aid all AIM personnel from students to staff members to directors, by offering a modest resource capable of providing greater cognizance of and appreciation for the background and scope of this important ministry they are nourishing by their efforts and serving the Lord in.

Finally, for both in-house and distance-based leadership giving guidance to AIM, it is hoped that this dissertation would help nurture encouraging reminders and nudge creative thinking for the vital and perpetual process of discerning, developing, and directing God's distinct mission for Adventist Information Ministry. 
CHAPTER TWO

INTERVIEWS

Dillman's Methodology Chosen

At the time of the recommendation from the Institute of Church Ministry to consider Dillman's Mail and Telephone Surveys: The Total Design Method, a handful of relevant books offering information on conducting interviews was read in part and considered. ' It was decided that Dillman's work offered the clearest and most helpful account of how to go about this task as it related to the doctoral dissertation."

${ }^{1}$ Paul Erdos, Professional Mail Surveys (Malabar, FL: Robert E. Krieger Publishing Company, 1983); Arlene Fink and Jacqueline Kosecoff, How to Conduct Surveys: A step-by-step Guide (Beverly Hills, CA: Sage Publications, 1985); Robert Groves and Robert Kahn, Surveys by Telephone: A National Comparison with Personal Interviews (New York: Academic Press, 1979); Survey Research Center, Interviewer's Manual, rev. ed. (Ann Arbor, MI: Institute for Social Research, 1976).

Erdos's work was not accepted because it was limited to a mail survey method that offered little advice for interview methodology. The book by Fink and Kosecoff was discovered to be the most useful of these four that were set aside. A few of their ideas are footnoted in this report. The title of Groves and Kahn's reference sounded worthwhile, but the work was found to focus on sampling random telephone numbers, with primary concern for detailed statistical analysis that was considered too theoretical for this project report. The University of Michigan Survey Research Center's book had a title that appeared to be beneficial, but it limited its interview method to a random yet calculated door-to-door approach. This work offered a chapter on "reinterviewing" by telephone, but its contents were just a page in length and duplicated principles best elaborated in Dillman's book.

${ }^{2}$ Given the Institute of Church Ministry's advice and the author's lack of experience in conducting research interviews, for 


\section{Philosophy of the Total Design Method}

What Influenced the Total Design

Method's Conception

When most people think of an interview, a face-to-

face encounter for a position of employment is what

generally comes to mind. When it comes to conducting a survey interview to gather data, people tend to think of knocking on doors and speaking with persons they do not know. In recent years, however, the door-to-door type of survey interview has met with "increasingly high cost and [the] difficulty of locating respondents." ${ }^{1}$ According to Dillman, these two problems in particular have influenced the attempt to generate some workable alternatives to the problematic method of conducting door-to-door interviews.

Many pastors, including the author, have experienced the same difficulty that interviewers face in locating people at home. The increase of households across this country in which both spouses work often results in no adult being home during much of the day. Added to this is the growing urbanization of lifestyles that results in people being away from their homes in pursuit of leisure activities. Still another reason is the increased geographical mobility for the purpose of employment by those

the sake of simplicity, continuity, and expediency it was decided to exclusively utilize the "Total Design Method" as a standard for the entire interview process, thus the multiple references to Dillman's work in this chapter.

$$
{ }^{1} \text { Dillman, } 2 \text {. }
$$


living in the United States, with nearly one-fifth of the population moving each year. ${ }^{1}$

To compensate for the problems thus inherent with locating interviewees at home for a face-to-face interview, Dillman created the "Total Design Method" (TDM), which in 1978 was published as a new approach to mail and telephone surveys. In essence, TDM consists of two parts:

The first is to identify each aspect of the survey process that may affect either the quality or quantity of response and to shape each of them in such a way that the best possible responses are obtained. The second is to organize the survey efforts so that the design intentions are carried out in complete detail. ${ }^{2}$

\section{Affecting Response}

In identifying aspects that seek to affect the survey process for the best possible response, Dillman noted that the "respondents' behavior is motivated by whether they expect the rewards to outweigh the costs of participating in a survey." ${ }^{3}$ He suggested several things that a researcher could do to facilitate a better response with interview participants. These items are listed on the following page in table 1 .

\footnotetext{
${ }^{1}$ Ibid. , 3.

${ }^{2}$ Ibid. , 12 .

${ }^{3}$ Ibid. , 18.
} 
TABLE 1

ENCOURAGING RESPONSE FOR POTENTIAL SURVEY RESPONDENTS

\begin{tabular}{|c|c|}
\hline A. & $\begin{array}{l}\text { Reward the respondent by: } \\
\text { * } \quad \text { showing positive regard } \\
\text { * giving verbal appreciation } \\
\text { * using a consulting approach } \\
\text { * } \quad \text { supporting his or her values }\end{array}$ \\
\hline B. & $\begin{array}{l}\text { Reduce costs to the respondent by: } \\
\text { * making the task appear brief } \\
\text { * reducing the mental effort required } \\
\text { * eliminating chances for embarrassment } \\
\text { * eliminating any direct monetary cost }\end{array}$ \\
\hline C. & $\begin{array}{l}\text { Establish trust by: } \\
\text { * identifying with a known organization } \\
\text { * building on other exchange relationships }\end{array}$ \\
\hline
\end{tabular}

Source: Don Dillman, Mail and Telephone Surveys: The Total Design Method (New York: John Wiley and Sons, 1978), 18.

\section{Survey Organization}

In observing a variety of surveys and interviews, Dillman noted that failures can take place due to a lack of organization with important details: "The failure of surveys to produce satisfactory results occurs as often from poor administration as from poor design." ${ }^{1}$ For example, one researcher was unable to implement a carefully timed follow-up procedure that required replacement questionnaires, because too few were printed. Another colleague established too large a sample size without carefully considering the costs of the 
follow-up process. As a result, he did not have sufficient funds to conduct the final phases of the planned follow-up and had to settle for a response rate that was less than adequate. Still another found herself without enough help to process followup reminders, thus personalization procedures were dropped, with a corresponding decline in response rate.

Dillman emphasized that a researcher should not assume these organizational matters will automatically fall into place. Instead, they must be intentionally planned and carried out. But, he said, "no matter how strenuously the point is made, it receives low priority because of the prevalent belief (better described as myth) that. . . organizational matters will take care of themselves." ${ }^{2}$

\section{A Mail Survey or Telephone Interview?}

With the "Total Design Method" having been chosen as a theoretical foundation for obtaining a sampling of opinion for this project, the actual type or method of TDM survey to be used was given consideration. Regarding which one might be chief among the alternatives, Dillman contended:

The question of which method is best cannot be answered in abstract terms. Although each method has certain strengths and weaknesses, they do not apply equally, or sometimes at all, to every survey situation. Thus, until the attributes of each method are considered in relation to the study topic, the population to be surveyed, and the precise survey objectives, the question of which is best cannot be answered. ${ }^{3}$

\footnotetext{
${ }^{1}$ Ibid. , 19.

${ }^{2}$ Ibid.

${ }^{3}$ Ibid. , 39.
} 
Considering Survey Characteristics

In comparing the viable mail questionnaire and telephone interview methods, there were two particular areas where no significant differences surfaced. One was the likelihood that selected respondents could be located. The second was the total allowable length for a questionnaire. ${ }^{1}$

When other performance characteristics were compared between the mail and telephone methods, an advantage in favor of the mail questionnaire was noticed in three areas: (1) the allowable complexity of questions, (2) the likelihood that interviewer distortion could be avoided, and (3) lower costs. ${ }^{2}$

However, for the purposes of this dissertation, the disadvantages of the telephone interview method quickly vanished as the benefits emerged in its favor. Table 2 presents these benefits as items $2,3,6,7,8$, and 11 , where a comparison of performance characteristics between the telephone and mail methods is summarized.

\footnotetext{
${ }^{1}$ Ibid. , 74.

${ }^{2}$ Ibid. , 74-75.
} 
TABLE 2

RATING OF MAIL QUESTIONNAIRES AND TELEPHONE INTERVIEWS FOR SELECTED PERFORMANCE CHARACTERISTICS

\begin{tabular}{|c|c|c|}
\hline $\begin{array}{l}\text { Performance } \\
\text { Characteristic }\end{array}$ & $\begin{array}{l}\text { Mail } \\
\text { Questionnaire }\end{array}$ & $\begin{array}{l}\text { Telephone } \\
\text { Interview }\end{array}$ \\
\hline \multicolumn{3}{|c|}{ Obtaining a Representative Sampling } \\
\hline $\begin{array}{l}\text { 1. Likelihood that selected } \\
\text { respondents will be } \\
\text { located }\end{array}$ & High & High \\
\hline $\begin{array}{l}\text { 2. Likelihood that unknown } \\
\text { bias from refusals will } \\
\text { be avoided }\end{array}$ & Low & High \\
\hline $\begin{array}{l}\text { 3. Success in avoiding item } \\
\text { non-response }\end{array}$ & Medium & High \\
\hline \multicolumn{3}{|c|}{ Questionnaire Construction and Question Design } \\
\hline $\begin{array}{l}\text { 4. Allowable length of } \\
\text { questionnaire }\end{array}$ & Medium & Medium \\
\hline $\begin{array}{l}\text { 5. Allowable complexity } \\
\text { with type of question }\end{array}$ & Medium & Low \\
\hline $\begin{array}{l}\text { 6. Success with open-ended } \\
\text { questions }\end{array}$ & Low & High \\
\hline $\begin{array}{l}\text { 7. Success with controlling } \\
\text { sequence of questions }\end{array}$ & Low & High \\
\hline $\begin{array}{l}\text { 8. Success with tedious or } \\
\text { boring questions }\end{array}$ & Low & Medium \\
\hline \multicolumn{3}{|c|}{ Obtaining Accurate Answers } \\
\hline $\begin{array}{l}\text { 9. Likelihood that } \\
\text { interviewer distortion } \\
\text { and subversion can be } \\
\text { avoided }\end{array}$ & High & Medium \\
\hline \multicolumn{3}{|c|}{ Administrative Requirements } \\
\hline $\begin{array}{l}\text { 10. Overall potential for } \\
\text { low costs per interview }\end{array}$ & High & Medium \\
\hline $\begin{array}{l}\text { 11. Potential speed of } \\
\text { implementation }\end{array}$ & Low & High \\
\hline
\end{tabular}

Source: Don Dillman, Mail and Telephone Surveys: The Total Design Method (New York: John Wiley and Sons, 1978), 74-75. 


\section{Special Characteristics}

In surveying the above-Iisted advantages of the telephone interview method, it was noted that four of the six favorable characteristics for telephone interviews were ranked especially high above a mail questionnaire (see performance characteristic 2, 6, 7, and 11). Reducing interview refusals, increasing success with open-ended questions, controlling their sequence, and increasing the potential speed by which the interview could be implemented were all viewed favorably by the author. It seemed reasonable that "if you need in-depth information and want to probe people's views, [telephone] interviews are better." ${ }^{1}$ Thus the telephone interview method became the obvious choice.

Finally, when considering the topic under study, there was an extra nostalgic factor that presented itself. Given the prominent role of the telephone at AIM since its inception, it seemed fitting to employ the very phone lines that had bridged AIM's outreach to hundreds of thousands of people in order to gather input for this research project.

\section{Constructing the Telephone Interview}

Throughout the process of drafting the interview instrument, the philosophical keys behind a TDM telephone questionnaire (encouraging response and survey organization)

${ }^{1}$ Fink and Kosecoff, 13. 
were kept in mind. Three items of additional importance further contributed to influencing the phone interview construction. These included the needs of respondents, the first few questions, and the implications of an interview instrument which relied entirely upon verbal communication. A sampling from each of these concerns is discussed below.

\section{Respondents' Needs}

"Often respondents are called to the telephone unexpectedly and are asked to do something that they do not yet fully understand." ${ }^{1}$ In an attempt to meet this need for those who might participate in this project, an interview introduction (see second page of Interview Instrument in Appendix D) was drafted to help each respondent understand the ramifications of the phone questionnaire in which he or she was being asked to take part.

"In addition," wrote Dillman, "people may be caught in the midst of activities they seek to continue even while on the phone. . . As a result, the respondent's attention may be focused only partially on the interview. " ${ }^{2}$ With the expectation that this could occur, a portion of the interview introduction sought to address this issue by asking if an interview was something that could fit into

${ }^{1} \mathrm{Dillman}, 202-203$.

${ }^{2}$ Ibid. 
their present schedule that day, or if it would be better to make an appointment for later in the week.

\section{First Questions}

No aspect of the question and ordering process is given more attention than the phrasing and content of the first few questions. . . If a response can be obtained to these questions the likelihood of a subsequent termination of the interview is greatly decreased. ${ }^{1}$

The dissertation's second committee member, Roger Dudley, reminded the author of the importance of the warm-up element in an interview's first few questions, as the final drafts of the instrument were taking shape. Abiding by this cue, and Dillman's suggestions as noted below, the interview questionnaire ${ }^{2}$ began with two close-ended questions in an attempt to ease participants into the interview, with inquiries that would be "relevant, interesting, easy to answer, and applicable to everyone in the study." ${ }^{3}$

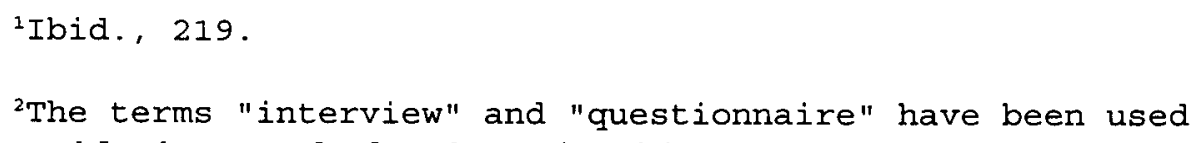
interchangeably here and elsewhere in this report. How to conduct Surveys: A step-by-step Guide links these terms together in this way: "Questionnaires and interview forms can look nearly identical because they share many important characteristics: They consist of (1) questions and (2) instructions, and they make sense only in the context of (3) sampling and design, (4) data processing and analysis, (5) pilot testing, (6) response rate, and (7) reporting results." Fink and Kosecoff, 16 .

The author is aware, however, that some fundamental differences do exist between these two terms. For example, the source just quoted also refers to the contrast between them by saying: "With questionnaires, the survey is limited to written responses to preset questions. With interviews, it is possible to ask for explanations and to provide information on the respondent's reactions." Ibid., 19.

${ }^{3} \mathrm{Dillman,} 219$. 
Never Seen but Heard

The TDM telephone questionnaire contrasts sharply with the TDM mail questionnaire. It is "heard" but never "seen" by the respondent. Thus it does not need the visual attractiveness and selfsustaining detail that are essential to the TDM mail questionnaire. However, neither can it be formed recklessly. If anything, the construction requirements are more rigorous. ${ }^{1}$

Recognizing that an interviewee and interviewer are totally dependent on verbal communication, an impetus was provided for ensuring that each word in every interview question would be phrased correctly. "Reducing question complexity" and "rotating response categories" ${ }^{2}$ were a few additional ways that the interview was modified in the final drafts to meet the challenge of being heard but not seen by the participant.

Organization and Objectives of the Interview Instrument

In an initial brainstorming session, multiple questions were drafted in relation to the project task. As the refinement process neared completion, the organization and objectives behind the questionnaire unfolded as follows.

Page 1 of the interview instrument was dedicated to organizational matters for each interview, with space for brief facts about the interviewee followed by phone call information. At the bottom of the page was a chart that

${ }^{1}$ Ibid. , 230.

${ }^{2}$ Ibid. 
identified which interview questions should be used for the six different groups of individuals to be interviewed.

Page 2 offered a written script for introducing the interviewer, the purpose behind the interview, and mention of the AIM director who was also supportive of the project. Reference was then made to the groups of individuals being called for phone interviews, followed by an invitation to participate and an inquiry into the best time for scheduling such a telephone interview. Next came requests for permission to tape record in order to ensure accuracy of reporting and to quote the participant when it would be appropriate to do so in the report. This. second page also contained the first two introductory questions of the interview.

Page 3, also known as "Section I," contained nine questions dedicated to discovering information that was either unknown or uncertain about "AIM's Historical Foundations." These questions were formulated to help uncover broad knowledge about AIM's conception and early development and to discover more detailed facts about items such as AIM's name, AIM's founder(s), or the key personnel and essential components of its start-up operations.

Page 4 offered six questions in "Section II" directed toward the "Theological and Missiological Foundations" of AIM. These questions provided an opportunity for the person being interviewed to describe his 
or her understanding of God's involvement in the AIM story and to elaborate on the mission of AIM along with the inspirational sources behind this mission mandate.

Pages 5 and 6 combined thirteen questions in "Section III" revolving around the work of "The AIM Chaplains." These ranged from open-ended questions about the chaplain's job training and accountability to the detailed ranking of the chaplain's functions in order of importance as contrasted with how time was actually spent.

Page 7 and a portion of page 8 in "Section IV" were reserved for input on "AIM Chaplain and Leadership Roles," with fifteen questions in all. Three basic questions asked for the interviewee's understanding of a named role, how that role could be improved, and what that role's most significant contribution was for AIM. These three questions were repeated for the roles of the AIM chaplain, senior chaplain, follow-up coordinator, director, and AIM executive steering committee.

Finally, the remainder of pages 8 and 9 found in "Section V" included ten questions under "Evaluation and Recommendations." The first few questions were directed toward the executive steering committee, followed by half a dozen questions regarding satisfaction with AIM's overall services. The final four questions asked how AIM may have benefitted or hindered the person being contacted, with opportunity then given for the interviewee to make 
recommendations for AIM's improvement or suggestions for services he or she wished that AIM would consider providing.

\section{Completed Questionnaires}

In consultation with the author's adviser and later with the director of the Institute of Church Ministry, the various drafts of the interview instrument went through a series of refinements before being ready for testing and Einal implementation. Several completed questionnaires were then assembled in preparation for the pilot testing of the telephone interviews. The completed interview instrument containing fifty-eight questions in all can be viewed in detail in Appendix D.

\section{The Pilot Phone Interview}

\section{In Principle}

According to Arlene Fink and Jacqueline Kosecoff, "all types of questionnaires and interviews must be pilot tested." The reason for this is because "pilot testing quickly reveals whether people understand the directions you have provided and if they can answer the questions." ${ }^{1}$

In regard to this tryout phase of the telephone interview, Fink and Kosecoff recommended to the research surveyor: "Whenever possible, you should try to duplicate the environment in which the survey is to take place." 2

\footnotetext{
${ }^{1}$ Fink and Kosecoff, 18.
}

${ }^{2}$ Ibid. 
Dillman, however, was not satisfied with simply recommending the environment be duplicated for the TDM telephone interview pretest. He believed it is an integral ingredient of the telephone questionnaire pilot interview:

It is absolutely essential that telephone questionnaires be tested over the telephone. Having respondents fill it out themselves or reading it to them in a face-to-face situation, does not provide an adequate pretest. In fact, it may do more harm than good. The face-to-face situation results in both the interviewer and respondent relying on visual cues; the questionnaire deficiencies may be missed. ${ }^{1}$

One reason cited for Dillman's insistence was that "testing over the telephone means that such things as normal line noise. . are components of the test situation, as should be the case." ${ }^{2}$ As it turned out, electronic deficiencies were soon to be discovered in the author's pilot interviews too.

\section{In Practice}

At the beginning of the workweek on April 25, 1994, voice mail messages were sent to five staff members at AIM, with an invitation to partake of a pilot telephone interview for this project. Two of these five returned voice mail

messages that same morning with an interest in participating in the pre-test and were available for scheduling a telephone interview sometime during the same day.

${ }^{1}$ Dillman, 229.

${ }^{2}$ Ibid. 
The AIM office cassette tape machine was tested and appeared to record and play back phone conversations properly. A pilot telephone interview got underway that morning with one of the AIM staff members and concluded forty-two minutes later. Immediately following the pretest, a ten minute de-briefing session took place with the interviewee. This is summarized in table 3 of the following page.

Electronic Recording Problems and a Decision to Move Ahead

Shortly after the de-briefing, the author attempted to play back the first pilot interview recording and was surprised to discover silence in its place. The AIM cassette tape machine was inspected by an electronically gifted AIM employee and re-tested by the author; however, the unit continued not to record. A new cassette tape machine with the needed remote microphone jack for a direct phone line feed was finally located later that day and purchased. Upon returning to AIM, the new unit was tested and, at that time, found to be properly recording and playing back telephone conversations.

By now the second AIM staff member who had responded favorably toward participation that day in a pilot phone interview was busy and would be so for the remainder of the afternoon through the next few days. Considering the 
TABLE 3

SUMMARIZATION OF PILOT PHONE INTERVIEW DEBRIEFING

\begin{tabular}{|c|c|}
\hline Questions from Interviewer & Responses from Interviewee \\
\hline $\begin{array}{l}\text { 1. Comment on the overall } \\
\text { interview instrument-- } \\
\text { its organization into } \\
\text { five sections, and the } \\
\text { order of questions. }\end{array}$ & $\begin{array}{l}\text { 1. I have answered a } \\
\text { number of surveys such } \\
\text { as this and felt yours } \\
\text { was one of the best } \\
\text { organized. }\end{array}$ \\
\hline $\begin{array}{l}\text { 2. What about the clarity } \\
\text { of questions--was any } \\
\text { question unclear? }\end{array}$ & $\begin{array}{l}\text { 2. The questions were very } \\
\text { clear. The only } \\
\text { unclear question was } \\
45--I \text { don't believe } \\
\text { it's the steering } \\
\text { Committee's job to } \\
\text { handle day-to-day } \\
\text { concerns of AIM staff. }\end{array}$ \\
\hline $\begin{array}{l}\text { 3. How did you feel about } \\
\text { the interview length? } \\
\text { You were told it would } \\
\text { take about } 30 \text { minutes, } \\
\text { and it took } 42 \text {. }\end{array}$ & $\begin{array}{l}\text { 3. The length was fine. } \\
\text { Of course, my working } \\
\text { with AIM guarantees a } \\
\text { high level of interest. }\end{array}$ \\
\hline $\begin{array}{l}\text { 4. Any concerns regarding } \\
\text { the interviewer's } \\
\text { voice--speed, pitch, } \\
\text { or clarity of } \\
\text { pronunciation? }\end{array}$ & $\begin{array}{l}\text { 4. Excellent. Very easy } \\
\text { to listen to and } \\
\text { understand. }\end{array}$ \\
\hline $\begin{array}{l}\text { 5. Any criticism you want } \\
\text { to offer which the } \\
\text { above questions have } \\
\text { not addressed? }\end{array}$ & 5. None. \\
\hline 6. Anything else? & $\begin{array}{l}\text { 6. I appreciated your } \\
\text { having prayer at the } \\
\text { beginning of the } \\
\text { interview. }\end{array}$ \\
\hline
\end{tabular}


positive feedback from the first pre-test interview, coupled with the author's experience and confidence with phone ministry at AIM, a decision was made to move forward into the major phone interview campaign beginning that afternoon.

Because of the positive feedback from the pilot phone interview de-briefing, no changes were made to the telephone interview instrument itself. Further copies were then assembled and made ready for the note-taking which would accompany the cassette recording of each interview.

\section{Conducting the Phone Interviews}

Sample Selection: Who and How Many?

When you decide to conduct a survey, you almost always have a fairly good idea of which people you want to include. The trick is to get enough people whose views count. ${ }^{1}$

With the decision to interview a variety of individuals by telephone who were associated with AIM, the following groups of people were chosen to provide input toward this dissertation's task:

AIM founders. Four persons' names had often surfaced in response to the author's casual inquiries of who had made significant contributions to the conception and founding of AIM. These four individuals were the first to be considered for participants in a telephone interview, and all four of them were able to be interviewed.

\footnotetext{
${ }^{1} \mathrm{Fink}$ and Kosecoff, 54.
} 
AIM chaplains. Close to fifty chaplains had served at AIM from the time of its inception to the spring of 1994. Of the six groups of people telephoned for interviews, current address information for the former chaplains was the most difficult to locate. Up-to-date phone numbers were finally acquired for thirty-eight AIM chaplains. Following 126 phone calls made, and 12 returned to the author, twentysix AIM chaplains were able to be interviewed.

AIM steering committee members. In reviewing the attendance record for the AIM executive steering committee meetings from 1984-1993, it was noted that five individuals had attended between ten to sixteen meetings, while another four persons were in attendance at three to five meetings. of these nine individuals (one of whom was an AIM staff member and another who was associated with the agency group, thus these two are accounted for in the two groups below), phone interviews were conducted with six of them.

AIM staff. According to the employment history of the five current staff members at AIM, four of these full-time AIM employees had each worked at Adventist Information Ministry for eight and a half years or more. Of these five AIM staff members who were contacted to participate in this dissertation report, phone interviews took place with four. 
Agencies. Ten individuals representing nine different media agencies which are recipients of AIM's services were approached with invitations to participate in phone interviews. The author was able to secure interviews with eight different persons from these media agency groups.

Pastors. Of the twenty-four pastors who were called for telephone interviews, fourteen of these attempts resulted in fruitful interviews. Though current phone numbers were readily available for this group of individuals, they were as difficult to make contact with as were the former chaplains of Adventist Information Ministry.

Agencies and pastors combined. Out of the sixtyfive telephone interviews that were conducted for this project, the agency and pastor groups combined for twentytwo of those interviews. This accounted for 33.8 percent of the total interviews. From this perspective, one third of the total sampled opinion gathered for this study came from individuals outside of AIM who are recipients rather than providers of AIM services.

However, a different perspective is gained when looking at the limited time expended per interview with these two groups, with the 5.2 hours spent interviewing the media agencies and pastors representing only 13.5 percent of the total time spend for conducting the project interviews. Given that the combined views of these two groups were later 
deemed inappropriate for use in the dissertation (see chapter 5 conclusions), this perspective rendered the loss of these viewpoints more bearable.

Interview Questions Asked and Question Flexibility

As indicated earlier, the same questions were not asked of each group of people contacted for interviews. Although every person agreeing to an interview heard the introductory information from the first two pages, each group of persons was asked selected questions from the interview instrument based on question relevancy for that particular group. For a detailed account of the specific questions asked of each group, see page 1 of the interview instrument in Appendix D.

On some occasions when interviewees were busy, not all of the interview questions assigned to a particular group were able to be asked. On other occasions when an interviewee had little to say in response to questions in a particular section, the author did not use follow-up questions such as "Is there anything else?" but instead moved to questions that might be more readily answered.

A further example of question flexibility can be demonstrated with interview question 29. Placed as the lead question in section IV dealing with "AIM Chaplain and Leadership Roles," this question asked: "What is your understanding of the role of the AIM chaplain?" Upon 
commencement of interviewing the AIM chaplains group, it was soon felt that this question would be better used as an introductory question to section III which dealt exclusively with the AIM chaplain. Before any potential answers of a more objective nature could be planted in the minds of the chaplain respondents, this open-ended question was thus relocated and used to discover what first came to the minds of these interviewees regarding the AIM chaplains' role.

Additional Electronic

Recording Problems

At the outset of the second day of conducting telephone interviews, it was discovered that the red-colored recording light on the newly purchased tape machine was not coming on. This came as a surprise because the new tape recorder had performed all of its functions accurately for each of the phone interviews on the previous day. The author wondered if the problem might be due to the interview occurring on the phone system's intercom line. Upon notifying the interviewee of the problem at the very beginning of the interview, the interviewee was called back on the phone system's outgoing calls phone line. As the red-colored recording light then came on for both voices, it was assumed that actual recording was taking place, and the interview commenced accordingly.

Upon playing back the recording of this interview following its conclusion, however, it was discovered that 
only the interviewer's voice had been captured on the recording. A careful scrutiny of the recording unit and its hook-up revealed that the author had incorrectly inserted the incoming phone-line into the "ear" jack positioned next to the correct "mic" jack. This error was avoided for the remainder of the telephone interviews.

A few days later, another recording problem was discovered. This was traced to the small interface unit situated between the cassette recorder and the telephone. At inadvertent times on the playback tape, recorded voices would be replaced by a loud electronic hum for a short period of time. Because this occurrence seemed to be happening only occasionally, and because a replacement for the interface unit would have to be ordered at what was considered by the author to be an excessive price, it was decided to forego replacing it.

Based on listening to more than 15 percent of the interview recordings in their entirety after the conclusion of the telephone interviews, it was estimated that these recorded segments of electronic noise could comprise 5 percent or less of the entire phone interviews on tape. Though deemed a small recording loss, for later playback purposes the author regretted having not replaced the unpredictable interface unit upon discovery of the problem. 
Summary of Phone Interview

Statistics

By group. In-depth interviews took place with individuals who had contributed to founding AIM. With one exception these AIM pioneers all attended at least one AIM steering committee meeting and are thus combined with the other AIM executive steering committee members in table 4, because of the difficulty in objectively identifying exactly who was and was not an AIM founder. Phone interviews with this combined group averaged 42.0 minutes per interview and totaled 7.7 hours.

Extensive interviews were carried on with current AIM staff members, averaging 59.2 minutes per interview for a total of 5.92 hours. Extended telephone interviews were also conducted with former and current AIM chaplains. These interviews took an average of 46.3 minutes to conduct with a total time of 20.05 hours, the most time taken with any of the five groups.

Partial interviews took place with individual ministers who have received contact from an AIM chaplain during the past few years. The average amount of time taken for phone interviews with this group was 13.3 minutes, with 3.1 hours of total interview time. Partial interviews were also conducted with representatives from the selected agencies that have been served by AIM through the years, which averaged 15.9 minutes in length. A sum of 2.12 hours was taken to conduct interviews with this group. 
Totals. Attempts were made to interview eightyeight individuals in all during this telephone research, which spanned a two-week period from April 25 through May 7 of 1994. Following multiple phone calls resulting in the author's inability to connect with twenty-six of these potential candidates, sixty-five telephone interviews were completed among sixty-two people, with two interviews occurring with one person and three interviews transpiring with another. The author made exactly 274 phone calls and had 28 calls returned to him for a total of 302 telephone calls exchanged, averaging 4.6 calls per conducted interview. During this phone research, a total of 2,333 minutes or 38.9 hours were spent on the phone with an average of 35.9 minutes transpiring for each of the sixtyfive interviews conducted. These phone interview statistics are summarized and displayed in table 4. The total costs of the telephone interviews were not calculated, primarily because the author was blessed with donated phone time from Adventist Information Ministry and his gracious parents. 
TABLE 4

TELEPHONE INTERVIEW STATISTICS

\begin{tabular}{|c|c|c|c|c|c|c|}
\hline & $\begin{array}{l}\text { Agencies } \\
\text { AIM } \\
\text { Serves } \\
\end{array}$ & $\begin{array}{c}\text { AIM } \\
\text { Chaplains } \\
\end{array}$ & $\begin{array}{l}\text { AIM } \\
\text { Founders/ } \\
\text { Committee } \\
\end{array}$ & $\begin{array}{l}\text { Pastors } \\
\text { AlM } \\
\text { Serves }\end{array}$ & $\begin{array}{c}\text { AlM } \\
\text { Staff }\end{array}$ & Totals \\
\hline \multicolumn{7}{|c|}{ PEOPLE } \\
\hline $\begin{array}{l}\text { 1. People Attempted } \\
\text { to Interview }\end{array}$ & 10 & 38 & 11 & 24 & 5 & 88 \\
\hline $\begin{array}{l}\text { 2. People } \\
\text { Interviewed }\end{array}$ & 8 & 26 & 10 & 14 & 4 & 62 \\
\hline $\begin{array}{l}\text { 3. Interviews } \\
\text { Conducted } \\
\end{array}$ & 8 & 26 & 11 & 14 & 6 & 65 \\
\hline $\begin{array}{l}\text { 4. Percentage of } \\
\text { Interviews conducted }\end{array}$ & 12,3 & 40.0 & $\begin{array}{l}16.9 \\
16\end{array}$ & 216 & 9.2 & 100.0 \\
\hline \multicolumn{7}{|c|}{ TIME } \\
\hline $\begin{array}{l}\text { 5. Total Minutes for } \\
\text { Interviews Conducted }\end{array}$ & 127 & 1,203 & 462 & 186 & 355 & 2,333 \\
\hline $\begin{array}{l}\text { 6. Average Minutes per } \\
\text { Interview Conducted } \\
\end{array}$ & 15.9 & 46.3 & 42.0 & 13.3 & 59.2 & 35.9 \\
\hline $\begin{array}{l}\text { 7. Total Hours for } \\
\text { Interviews Conducted }\end{array}$ & 2.12 & 20.05 & 7.70 & 3.10 & 5.92 & 38.89 \\
\hline $\begin{array}{l}\text { 8. Percentage of } \\
\text { Total Time }\end{array}$ & 5.4 & 51.6 & 198 & 8.0 & 15.2 & 100.0 \\
\hline \multicolumn{7}{|c|}{ CALLS } \\
\hline $\begin{array}{l}\text { 9. Phone Calls Made } \\
\text { by Interviewer }\end{array}$ & 27 & 126 & 37 & 67 & 17 & 274 \\
\hline $\begin{array}{l}\text { 10. Phone Calls Returned } \\
\text { to Interviewer }\end{array}$ & 0 & 12 & 3 & 7 & 6 & 28 \\
\hline $\begin{array}{l}\text { 11. Total } \\
\text { Phone Calls }\end{array}$ & 27 & 138 & 40 & 74 & 23 & 302 \\
\hline $\begin{array}{l}\text { 12. Percentage of } \\
\text { Total Phone calls }\end{array}$ & 8.9 & 45.7 & 133 & 24.5 & 7.6 & 1000 \\
\hline $\begin{array}{l}\text { 13. Average of } \\
\text { Total Phone Calls per } \\
\text { Interview Conducted }\end{array}$ & 3.3 & 5.2 & 3.6 & 5.3 & 3.8 & 4.6 \\
\hline
\end{tabular}


CHAPTER, THREE

FOUNDATIONS

\section{Some Missiological Foundations}

\section{Christ's Great Commission}

In the second section of the telephone interviews that undergird this dissertation, interviewees were asked to identify "theological and missiological foundations" that might have been used as philosophical support to help build the foundational concepts of Adventist Information Ministry. Directed to the AIM staff, steering committee and founders, the thirteenth question of the interview asked: "In formulating AIM's mission, what Bible passages would the founder(s) have had in mind?" In reply, one interviewee referred to the verses found in the gospel of Matthew's twenty-eighth chapter known as Christ's Great Commission.'

Then Jesus came to them and said, "All authority in heaven and on earth has been given to me. Therefore go and make disciples of all nations, baptizing them in the name of the Father and of the Son and of the Holy Spirit, and teaching them to obey everything I have commanded you. And surely I will be with you always, to the very end of the age." ${ }^{2}$

${ }^{1}$ Staff \#85, telephone interview by author, April 24, 1994.

${ }^{2}$ Matt $28: 18-20$ (NIV). 
Ellen White on Evangelism

The evangelistic mandate given by Jesus Christ has been extensively elaborated upon in the writings of Ellen White. Among White's prolific writings are found over 125 references ${ }^{1}$ to the Matt 28:18-20 text containing Christ's Great Commission. Nearly a century ago, white made the following comment in reference to this cornerstone passage of Scripture:

The very life of the church depends upon her faithfulness in fulfilling the Lord's commission. To neglect this work is surely to invite spiritual feebleness and decay. Where there is no active labor for others, love wanes, and faith grows dim. ${ }^{2}$

No greater work. A comprehensive, topically arranged compilation of 700 pages devoted exclusively to the subject of Evangelism has been available from Ellen white's writings since 1946. In this volume, white sets forth the lofty calling associated with the most important undertaking possible on planet Earth by saying: "The conversion of souls to God is the greatest work, the highest work, in which human beings can have a part." ${ }^{3}$

\footnotetext{
${ }^{1}$ Board of Trustees of the Ellen G. White Estate, Comprehensive Index to the Writings of Ellen G. White (Boise, ID: Pacific Press Publishing, 1962), 104 .

${ }^{2}$ Ellen White, Desire of Ages (Mountain View, CA: Pacific Press Publishing, 1898), 825 . 1946), 292 .

${ }^{3}$ Ellen White, Evangelism (Washington, DC: Review and Herald,
} 
Ministerial priorities and the value of a soul. With soul-winning at the very pinnacle of human labor in Ellen White's estimation, she is quick to point out the tremendous need for prioritization that comes with this dimension of ministerial work. According to White, a minister of God should place all other interests in subjection to the high calling assigned to evangelism, given the remarkable value of the human soul.

There are no circumstances of sufficient importance to call a minister from an interest created by the presentation of truth. Even sickness and death are of less consequence than the salvation of souls for whom Christ made so immense a sacrifice. . . One soul is of more value than the entire world.

\section{The importance of evangelistic follow-up. Question}

14 of the interview instrument inquired, "What comments from Ellen white would have impacted the AIM founder(s) in establishing the mission of AIM?" Of the eight founders/ steering committee members and AIM staff who replied to this question, four of the interviewees indicated "none," "don't recall" or "unknown." From three of the remaining four respondents, however, the author was pointed to one or two of Ellen G. White's comments on the all-important concept of "follow-up."

Within the context of prioritization in evangelism, White speaks of the imperative of following up an

${ }^{1}$ Ellen white, Testimonies for the Church, 9 vols. (Mountain View, CA: Pacific Press Publishing, 1948), 2:540-541. 
evangelistic interest to ensure that the interest: (1) makes a decision for Christ, (2) has a conversion experience, (3) becomes baptized, and (4) unites with a church in membership. She says:

For years light has been given upon this point, showing the necessity of following up an interest that has been raised, and in no case leaving it until all have decided that lean toward the truth and have experienced the conversion necessary for baptism and united with some church or formed one themselves. ${ }^{1}$

The above admonition was spoken against a backdrop of certain individuals who were "charmed with the beautiful chain of truth," yet were not properly followed-up and spiritually abandoned. In response to the negligent minister who was responsible, White said: "You left the field without completing the work you had undertaken. This was worse than if you had never entered it. That interest can never be raised again." ${ }^{2}$

Given White's admonitions spoken about the importance of follow-up work in evangelism, it is little wonder she stated the following potent principle referred to by two of AIM's pioneers during the interviews: "Preparatory work is not of one half the value that the afterwork is." ${ }^{3}$

\footnotetext{
${ }^{1}$ Ibid. , 540 .

${ }^{2}$ Ibid.

${ }^{3}$ White, Evangelism, 432 .
} 
Slackness in follow-up makes the angels weep. White, however, is not alone in her concern for the "afterwork" aspect of ministerial work. Apparently, even the mighty angels of God are emotionally distressed when the evangelistic interests of the church are not cared for properly. She says in this regard:

The work should not be left prematurely. See that all are intelligent in the truth, established in the faith, and interested in every branch of the work, before leaving them for another field. And then, like the apostle Paul, visit them often to see how they do. Oh, the slack work that is done by many who claim to be commissioned of God to preach His Word, makes angels weep. ${ }^{1}$

\section{Evangelism: Heartbeat}

of Christianity and

the SDA Church

According to a Seventh-day Adventist Encyclopedia

article devoted to the topic of "Public Evangelism," Adventists have always viewed soul-winning as the very center of Christianity and their church.

SDA's believe that evangelism--the proclamation of the gospel--is the very heart of Christianity. From the early days of the SDA church, public evangelism has played a major role in the growth and development of the denomination. ${ }^{2}$

Beginning with a few faithful preachers who held evangelistic meetings among small groups of interested believers in the early 1840s, public evangelism has continued to be an important aspect of soul-winning for

${ }^{1}$ White, Testimonies for the Church, 5:256.

${ }^{2}$ SDA Encyclopedia, 1976 ed., s.v. "Evangelism, Public." 
Seventh-day Adventists, regardless of the modifications made in more recent years with public evangelism's methodology. ${ }^{1}$

As times changed, methods also changed, and evangelism has come to include radio and television programs, correspondence lessons, and other methods.

International broadcasts such as the Voice of Prophecy, Faith for Today, and It Is Written are a focal point for evangelism. . . . It Is Written builds its program around the purchase of time on television stations with local follow-up through personal visiting and public meetings. ${ }^{2}$

\section{Annual Council's call for successful follow-up}

methods in 1976. With General Conference president Robert H. Pierson preaching "powerful calls" of "revival and reformation" for the Seventh-day Adventist Church, the Annual Council of SDA church leaders expressed its response in 1976 by saying:

It is our conviction that if a sense of mission and commitment to evangelizing the world in an unprecedented manner is brought before the church through bold leadership we will witness a true revival and reformation. ${ }^{3}$

Given this Annual Council conviction, a ten-point plan of action was set forth to give absolute priority to evangelism at all levels. Included as the ninth point in this plan was a burden for "successful follow-up methods" in relation to SDA media evangelism, stated as follows:

${ }^{1}$ Ibid.

${ }^{2}$ Ibid.

3"Annual Council Action on Evangelism and Finishing God's Work," Ministry, December 1976, 4. 
The North American Division leadership should make use of the existing Radio, Television and Film Center in Thousand Oaks, California, to provide radio-television and audio-visual evangelistic programs or "spots" that will most effectively and quickly warn the population of the world that Christ will soon return, and that will urge the necessity of final preparation. We should not rest until we find successful follow-up methods that involve the members of our local churches. ${ }^{1}$

NAD evangelism outlook in the early 1980s. While evangelism has always been important to the church in principle, some Seventh-day Adventists have had a problem in consistently believing it is possible to practice evangelism successfully. Charles Bradford spoke to this very matter in relation to the North American Division during the time of his presidency, in a sermon he preached on september 6 , 1980, titled: "The High Cost of Evangelism."

Somebody has said that North America is dead. Nothing is going on. No souls are being saved. Some have said, "Well, you can't do evangelism here. The people are different here. They're more affluent here. They're materialistic here. Oh, you might be able to do evangelism down in InterAmerica. They don't have money. They have nothing else to do. But it's different here."

With understanding toward how these feelings of discouragement can be generated, Bradford did not deny the difficulty of the evangelistic task. He admitted that sometimes "things are going badly. But you still fight the battle." He thus viewed the complacent attitude being

${ }^{1}$ Ibid. , 10.

${ }^{2}$ Charles Bradford, "The High Cost of Evangelism," Ministry, June 1981, 11 . 
expressed toward evangelism in the NAD as destructive, pointing out that it was becoming a self-fulfilling prophecy in the division he superintended: "We've kept telling ourselves that for so long that we're beginning to believe it." Consequently it was his determination to reverse the "we can't do it, so we don't do it" attitude regarding evangelism in the NAD. ${ }^{1}$ He thus asked:

Can we neglect the sacred trust and deny that Man who died on the cross? Can we turn our backs on a dying world? No, we cannot do it, for when we see Calvary we find out the worth of a soul. So I will not complain anymore.

The blood. The sweat. The tears. All the sacrifice. Brother, it's cheap enough, isn't it? For one soul our Saviour would die. ${ }^{2}$

\section{Giving unquestioned priority to SDA evangelism in}

1981. In October of 1981, some 320 Seventh-day Adventist leaders from around the world met in Takoma Park, Maryland, to conduct the annual business of the SDA church. In response to "a crisis of mission" that the Seventh-day Adventist Church had been facing in North America in particular and elsewhere, the entire council was characterized by "a pervading spirit of the church's mission." ${ }^{3}$

\footnotetext{
${ }^{1}$ Ibid.

${ }^{2}$ Ibid.

${ }^{3} \mathrm{~W}$. B. Quigley, "One Thousand Days of Reaping," Ministry,
} February 1982, 8 . 
The evangelistic flavor of this council was epitomized best on the final day of their meetings when church leadership voted "an unprecedented worldwide soulwinning thrust, placing unquestioned priority on evangelism in all forms and at all levels." The document that spelled out the plan was entitled "Prioritizing Evangelism--One Thousand Days of Reaping."1

The evangelism plan voted by these leaders called for baptizing 1,000 people per day for 1,000 days, between September 18, 1982, and June 15, 1985. It was hoped that a million souls would be added to the kingdom of God and the ranks of the Seventh-day Adventist church prior to the 1985 General Conference Session.

\section{A letter from the General Conference President in}

1982. In regard to the One Thousand Days of Reaping, Neal Wilson, President of the General Conference of Seventh-day Adventists, addressed his fellow workers in April of 1982 with a personal letter published in Ministry magazine. Reflecting on his feelings and admonitions toward the one Thousand Days of Reaping, Wilson said in his candid address:

If the church is weak and given to lesser goals, it is probably because leadership has permitted an emphasis that gives priority to business and organizational matters, rather than to spiritual revival and the reaping of earth's final harvest.

\footnotetext{
${ }^{1}$ Ibid.
} 
The challenge is to do whatever we need to do in our individual programs in order to give evangelism first place. Perhaps this will require much faith and even torturous struggle in some cases. Let us emancipate ourselves, even if it means entrusting to God and others some of those things that formerly consumed so much of our time and effort! And let us go forth with sanctified resolve to give priority to the work of soul winning. ${ }^{1}$

\section{Some Foundational Tools}

\section{7: Telephone Evangelism}

Approximately fifteen years before the inception of Adventist Information Ministry, a how-to-do-it book by the ministerial secretary of the Southern Union Conference of Seventh-day Adventists presented "one of the most exciting applications of modern communications technology to evangelism." ${ }^{2}$ Author Harold Metcalf, who as a young lad was reared in a home without such a communications device, invited fellow church members back in 1967 to consider:

The telephone is used to good advantage by every business in the world. If it can be used so advantageously to sell various products, and to make money, why couldn't it be used to tell men and women of God's truth for these latter days? ${ }^{3}$

Apparently Metcalf was not alone in using telephone technology for reaching out to individual people with an evangelistic purpose in mind. "Don Grey in particular had

${ }^{1}$ Neal Wilson, "Our First Business," Ministry, April 1982, 2.

${ }^{2}$ Harold E. Metcalf, "A Note About This Book," in The Magic of Telephone Evangelism (Atlanta, GA: Southern Union Conference, 1967), no page number.

${ }^{3}$ Ibid. , Preface. 
shown how to use the telephone ministry," said Des Cummings, Jr. And Cummings himself had started a telephone answering service for teenagers during the late sixties, while working as a pastor in Nashville, Tennessee. ${ }^{1}$

\section{2: Database Plan Proposed}

When the Annual Council of Seventh-day Adventists met in Mexico City, Mexico, a plan was presented by Robert Moon, then assistant professor of education at Andrews University. ${ }^{2}$ Moon's proposal in 1972 revolved around a database for keeping track of Seventh-day Adventist employees for potential employment. The idea was voted down, however, which caused some of these early dreamers of ideas that someday would be considered more seriously for Adventist Information Ministry "to go home and lick their wounds, but then come back to re-start the idea" with further developed concepts at a more opportune date. ${ }^{3}$

1976-1982: Combining Literature Evangelism and the Telephone

Some fifteen years after Harold Metcalf published his book on The Magic of Telephone Evangelism, another Seventh-day Adventist by the name of J. Roger McQuistan

${ }^{1}$ Des Cummings, Jr., telephone interview by author, May 7, 1994.

${ }^{2}$ Andrews University Bulletin, vol. 60 (Berrien Springs, MI: Andrews University, 1971-1972), 203.

${ }^{3}$ Robert Dale, telephone interview by author, April 27, 1994. 
published his outreach experience in utilizing the telephone:

For the past six or seven years I have had the privilege of piloting an exciting new concept in outreach through the combined use of literature and telephone. I have discovered that in many cases people will respond more favorably to the spiritual approach over the telephone than in a face-to-face confrontation. ${ }^{1}$

McQuistan indicated that the primary purpose for his staff position with Southern Publishing Association's These Times magazine was "to develop a program that would dovetail the dynamics of [the] telephone with the power of 'These Times' into a smooth-flowing system of church growth." ${ }^{2} \mathrm{He}$ went on to say:

Such experiences have completely convinced me that God has a definite place for the combined use of literature and telephone in His divine plan to reach a world with the three angels' messages. It provides for an extremely cost-effective way to touch large numbers of people quickly and in a significant way. ${ }^{3}$

\section{6-1979: NAD Tools Committee}

During the year of the bi-centennial celebration in the United States, a think-tank composed of Robert Dale, Charles Dudley, Phil Follet, Bruce Johnston, and Don Reynolds began meeting. Some time after this beginning, two of the original five dropped out, with Dale, Follet, and

${ }^{1} \mathrm{~J}$. Roger McQuistan, Telephone Ministry (Washington, DC: Review \& Herald Publishing, 1982), 9.

${ }^{2}$ Ibid.

${ }^{3}$ Ibid. 
Reynolds continuing on every quarter for about three or four years. Eventually, this think-tank grew in size to include between ten to fifteen people and was referred to by name as the "Tools Committee."

While discussing various ideas for the development of the Seventh-day Adventist Church in the North American Division, the question arose among the members of the Tools Committee: "How are we going to communicate?" ${ }^{2}$ In response to this question and other concerns for fulfilling the evangelistic mission of the church, this think-tank developed a fifty-page document offering organizational strategy and suggestions for its implementation.

According to Robert Dale, the concepts in this document were followed for some years throughout the North American Division, and from it came the Faith Action Advance (FAA) concept and the Caring Church model. As Dale commented during an interview with the author: "Many of the things we are doing today [in the NAD in the early 1990s] came out of this think-tank. This is the beginnings of where [the] AIM [concept] started." ${ }^{3}$

${ }^{1}$ Dale, interview, April 27, 1994.

${ }^{2}$ Ibid.

${ }^{3}$ Ibid. 
1980s: The Tool of the Decade

Around the time period that the Tools Committee was in gear, a technological breakthrough was rising on the horizon which would soon become known at Andrews University and all around the globe as: "The Tool of the Decade."

As the 80s dawned, a new technological "creature" slowly invaded the campus. Through the 70s, its bulky ancestors had lurked in remote corners of the Administration Building basement and a few other obscure spots on campus.

Then in 1983, with official academic decree mandating that students must take courses with the new technology, the invasion was complete. Andrews was officially "computerized."

During the sixties, the author remembers his father, a graduate of Oregon state Úniversity in civil engineering, driving and carrying a cumbersome Monroe calculator between his den at home and his office across town when working to execute mathematical calculations for estimating potential jobs as a general contractor. Upgrading a machine the size of a large typewriter and the weight of a bowling ball to a hand-held calculator weighing less than one pound a decade later was an impressive advance in technology. Yet, the computer of the eighties made the electronic calculator of the seventies pale by comparison. By 1986, reverberations from the computer now touched every corner of University Iife:

Sitting in the basement of the Administration Building at Andrews University are two Sigma computers, day and night accessing and processing

"The Tool of the Decade," Focus, Summer 1990, 15. 
stored data for academic and administrative use equal to ten thousand 200-page books. ${ }^{1}$

\section{Linking Two Technological Tools}

The pervading impact made by this powerful, dataprocessing machine was simply staggering, to say the least. As the telephone had brought trend-setting advances for communicating evangelistically in the sixties, so the computer would usher in a new era for the organization and processing of mega-amounts of information for church evangelism in the eighties.

The linking of the computer and the telephone was soon to unfold and be witnessed as an important development within a new Institute on the campus of Andrews University. With the remarkable capacities of these two tools wed together for the purpose of uniting people in a relationship with Jesus Christ, the creation of an outreach service such as Adventist Information Ministry could now become a technological possibility.

\section{Some Institutional Foundations}

\section{Institute of Church Ministry}

When asked the first question from section I of the dissertation's telephone interview: "Who first conceived of the original, initial idea for AIM?" Des Cummings, Jr., $1986,14$.

\footnotetext{
${ }^{1}$ William Cash, "The Computer Comes to Campus," Focus, Spring
} 
stated his belief that: "It arose out of a consultation with the Institute of Church Ministry." ${ }^{1}$

Organized in 1979, ICM [the Institute of Church

Ministry] is a branch of the Theological Seminary of Andrews University. It seeks to put the personnel, media, and data-processing resources of the University to the service of the church. ${ }^{2}$

\section{As "an official extension" of the SDA Theological}

Seminary at Andrews, the affiliation between the University, Seminary, and ICM combined for an important network "to help strengthen and coordinate all aspects of the ministry of the church." ${ }^{3}$

\section{Blending ministry-minded research with technology.}

A year after the Institute of Church Ministry had been

formed, Cummings, who in the Institute's beginning served as executive secretary and soon thereafter as director, proclaimed that ICM used "proven methods of evangelism and ministry blended with scientific research" to accomplish its mission." To facilitate the research aspect of the Institute of Church Ministry, it was said that:

The largest databank in the world on North American Seventh-day Adventist Church growth is available on computer at the seminary and will be

\footnotetext{
${ }^{1}$ Cummings, interview, May 7, 1994.

${ }^{2}$ Roger Dudley, "Editor's Perspective," Administry, Autumn 1982,2 .
3 "Institute Created to Promote Church Growth, " Focus, Summer 1980,5

${ }^{4}$ Ibid. 
used to evaluate information gained through research. ${ }^{1}$

For Cummings, the importance of research was not to be underestimated. In speaking to the Church's evangelistic agenda for the eighties, he said:

It is vital that study be given to the types of people the church is reaching through all evangelistic methods, and then develop new methods to reach people that are not being touched by present methods. Evangelism will not become outdated if it is updated through research. ${ }^{2}$

The leadership of the Institute of Church Ministry was careful not to equate "research" with what the church believes is the ultimate "resource" for evangelism. As a balanced testimony to this belief, ICM compared its research work with the greatest resource available to the church in humbly saying:

We wish to acknowledge frankly that scientific research can never substitute for the Holy Spirit. Without His power working in the church, real growth can never take place. And yet God does not send the Holy Spirit to sanction ignorance. . . . As we have pursued our work, we have faithfully tried to follow the motto that "knowledge is power only when united with true piety." ${ }^{3}$

Wide-ranging operations. With a dedication to advancing the North American Division's Faith Action Advance principles for evangelism and ministry, ICM early engaged in

${ }^{1}$ Ibid.

${ }^{2}$ Des Cummings, "The Church's Agenda for the 80's," Focus, Spring 1981, 26 .

${ }^{3}$ Roger Dudley and Des Cummings, Jr., Adventures in Church Growth (Washington, DC: Review and Herald Publishing, 1983), 11. 
a wide variety of tasks to help meet its objectives. Roger Dudley, then associate director and later director of the Institute, outlined the operations of the Institute of Church Ministry in 1982 :

ICM operates by conducting surveys and other research studies, compiling demographic profiles of major cities, conducting continuing education experiences, preparing curricular materials, performing telephone services, assembling resource materials, and consulting with pastors and administrators. ${ }^{1}$

ICM's Key Contributions toward AIM's Conception

Research studies and telephone services. As stated above, ICM did encompass a much broader scope than the tasks of conducting research studies and performing telephone services. While these two functions of the Institute of Church Ministry would be instrumental for the conception of Adventist Information Ministry, still other important developments were in the making for ICM.

\section{Des Cummings Jr.'s burden for practical seminary}

training. The Institute of Church Ministry was only one of a number of interests that Cummings had, during his tenure at Andrews University. The Office of Human Relations and the Youth Resource Center both had their start with the Institute of Church Ministry, due to Des's entrepreneurial gift for starting ministries. However, it was an additional 
interest brewing in Cummings's mind that would propel

Adventist Information Ministry's growth out of ICM. As Craig Willis told the story:

Des was concerned that people in the field perceived that there was a great lack of practical training in the Seminary. Des wanted to develop some way to have practical training in the Seminary that would have hands-on experience, without the problem of busing everybody to some evangelistic effort and watching one man speak, which was not accurate with the goal of having everyone involved with personal soul-winning. ${ }^{1}$

While teaching as an assistant professor in the Church Ministry department of the Seminary, Cummings was pursuing his Ph.D. degree in Religious Education from the School of Graduate Studies at Andrews University. From this combined experience he explained his personal interest in a more practical outreach component for the seminary:

Another thing impacting me was I was really studying Christ's model of training his disciples for ministry. I did a research paper for my doctoral work on models of education and theology of religious education, and out of that came to the conclusion that the only biblical model that was identifiable was discipling.

That discipling model became troublesome to me because we didn't have an opportunity to disciple our students as professors in real-life situations with real-life people, whereas Christ spent time with his disciples walking along with people, and the School of the Prophets was modeled after the same thing. And I really became convicted that we had to do something, to help students create that relationship skill of relating Christ one to one, whether it was on the telephone or whatever it was. ${ }^{2}$

${ }^{1}$ Craig Willis, telephone interview by author, May 2, 1994.

${ }^{2}$ Cummings, interview, May 7, 1994 . 
Consultation services for SDA media telecasts. In mid-1980, ICM was contacted by "Faith for Today," a telecast sponsored by the SDA Church, to perform "consultation services to ensure better follow-up procedures of individuals who have been involved in Faith for Today ministries." 1 Apparently "It Is Written" was also in contact with ICM for consulting services during this time. ${ }^{2}$ Reflecting back on these consultations performed by the Institute of Church Ministry, Cummings said:

We began to look at some of the facts and research on the consult. We actually charted through on a flow chart how long it took for people to get some of these items they requested from Faith For Today and It Is Written. It was found that the cycle time was extensive, about 13 weeks from the time that they would call until the time that they would receive their material. ${ }^{3}$

The fact that it took an entire quarter of a year to receive a package of requested literature was a predicament

"Highlights of the Andrews University 800 Number: Interest Identification and Follow-Up System, " unpublished TMS, 1, document believed to be written by Des Cummings, Jr., sent to author by Lowell Witz, received June 1,1994 .

${ }^{2}$ Robert Moon, secretary, "Minutes of Ad Hoc Committee on 800 System to Support Media Evangelism," December 7, 1981, unpublished TMs, received from Lowell Witz.

The above minutes reported that It Is written "has been in communication with Andrews University for over six months." This would place It Is Written's communication with the Institute of Church Ministry no later than the spring of 1981.

${ }^{3}$ Cummings, interview, May 7, 1994.

Cummings reports, however: "This was different in areas where IIW was. . . in confined areas such as in Michigan where experiments with Don Grey were involved. They were turning that around, keeping books right on site and doing it very quickly, and they were having much better follow-up results, much better follow-through, and much better response in terms of people actually joining the church." Ibid. 
that needed to be solved. Both Faith for Today and It Is Written were experiencing this problem with slow response time. According to ICM leadership, the reason the time dilemma needed to be solved was because:

We basically followed the logic of a principle we laid down early on: that what Christianity is all about is building relationships, and anytime you let a relationship cool for 13 weeks you've communicated the wrong thing to people. ${ }^{1}$

A pivotal question. Noting improved follow-up that was occurring for SDA telecasts in some experimental locations, the consultation revealed certain places in the United States where volunteer representatives of the telecasts under study were able to efficiently answer the phone in an effective way. But the problem with particular segments of the It Is Written phone crew was: (1) they could not consistently get their volunteer people to answer the phone on a regular basis; and (2) when volunteers were present, they tended to be available for only two to three hours on sunday immediately after the program had been aired.

Consequently, when callers who had been unable to get through on the few lines available tried to call back a few hours later, the local representatives for that telecast had all gone home, leaving no one available to answer the 
phone. ${ }^{1}$ In response to these findings, Cummings asked what appears to have been a pivotal question for the conception of this latest ICM-based development now brewing:

What could happen if we made a telephone number available around the clock? 800 numbers had started to become prominent with business in general, though they hadn't really gotten into the religious community around 1980. So as a result, what we decided to do is to implement a national or wider strategy, a pilot project, of answering the telephone, and try to do that on a regular basis. ${ }^{2}$

\section{Computing Center Contributions}

Bob Moon. Since the 1974-1975 school year, Bob Moon was serving Andrews University as an Associate in Administration with the specific title of Director of Institutional Research. ${ }^{3}$ In 1981, his position changed to Assistant to the President for Management Information and Planning," to whom the director of the computing center reported. According to Cummings, Moon was particularly helpful in winning the support and resources of the University administration for this unfolding project. ${ }^{5}$

Lowell Witz. In 1981 Lowell Witz was serving as one of Andrews University's "Associates in Administration," and

${ }^{1}$ Ibid.

${ }^{2}$ Ibid.

${ }^{3}$ Andrews University Bulletin, vol. 63, no. 4 (Berrien Springs, MI : Andrews University, 1974-75), 233.

${ }^{4}$ Andrews University Bulletin, vol. 70, no. 5, 225 .

${ }^{5}$ Cummings, interview, May 7, 1994. 
more specifically as the "Computing Center Director." ${ }^{1}$ In Cummings's words:

Lowell Witz was a godsend on this thing because he took it as a personal mission and did a lot of innovation on time that we didn't have to purchase. He got his folks involved at the computing center, and they did a lot of brainstorming. Lowell did a lot of the private work and piloting and conceptual work and came up with a lot of the locations and the ideas and the systems, [as well as] developing the programming strategy. ${ }^{2}$

Technical help and equipment. During this time period in 1981, the Andrews University Computing Center had twenty-one full-time staff and twenty-five students for a departmental total of forty-six people. This provided "a resource of technical help that cannot be duplicated elsewhere within the church. ${ }^{3}$ The department had two Xerox computers, a Sigma Six and a Sigma Seven, with "128K words of memory." This computer hardware system was valued at $\$ 1,500,000$, and supported nearly 100 on-line terminals. According to computing center personnel, at the time of the 800-number proposal to It Is Written (to be further revealed in the following pages of the dissertation): "We foresee no

${ }^{1}$ Andrews University Bulletin, vol. 70, no. 5, 225 .

${ }^{2}$ Cummings, interview, May 7, 1994.

${ }^{3}$ Des Cummings, Robert Moon, and Lowell Witz, "Preliminary Proposal to It Is Written By Andrews University to Provide Listener Request Processing, Interest Follow-Up, and Donation Processing Services," unpublished TMs. See Appendix B, section titled: "Summary of Andrews University Computing Center". 
problems in adding an additional 20 terminals for It Is Written." 1

\section{The Birth of Adventist Information Service and Adventist Information Ministry}

Institute of Church Ministry's

Toll-Free Telephones

Pilot Project

In response to the decision to set in motion an $800-$ number pilot project, the Institute of Church Ministry gathered together some funds for the installation and operation of four telephones with a toll-free 800 number for It Is Written. "More than likely this was the summer of ' 81 we did the pilot project for It Is Written." ${ }^{2}$

As ICM began answering phones for It is Written's Sunday telecasts, it soon became apparent that they could turn the information around much more quickly than was previously being done. With Cummings and Dudley working together with assistance from a small number of seminary students, the pilot project proved that the 800 -number concept realiy worked. ${ }^{3}$

We basically looked at that as what we could do and what we could get the costs down to. We got it to where we sat down with our computing people, and that's really when Bob Moon, and myself, and Lowell Witz came together. ${ }^{4}$

${ }^{1}$ Cummings, interview, May 7, 1994.

${ }^{2}$ Ibid.

${ }^{3}$ Ibid

${ }^{4}$ Ibid. 
ICM's Visionary 800-Number Proposal to It Is Written

Consulting services previously performed by ICM for two SDA media agencies apparently had led to the 800 -number pilot project for It Is Written (IIW). In like manner, the IIW pilot project paved the way for ICM's twenty-seven-page proposal in 1981 to It Is Written for an ongoing and more sizable 800 -number Watts Iine service to be located at Andrews University.

Proposal overview. Des Cummings, Bob Moon, and Lowell witz collaborated together as the chief architects ${ }^{1}$ for a "Preliminary Proposal to It Is Written by Andrews University to Provide Listener Request Processing, Interest Follow-Up, and Donation Processing Services" ${ }^{2}$ (see Appendix B) This document contained a precisely defined vision that was introduced by saying:

Andrews University's Institute of Church Ministry and Computer Center have combined resources to provide a service designed to assist mass entities of the church in fulfilling their mission. This service includes the following activities:

1. A Watts line (nation wide toll-free) answering service.

${ }^{1}$ Des Cummings's proposal contribution was confirmed in a phone conversation with Cummings by the author on June 15, 1994. Robert Moon verified his contribution to the proposal in the author's office on June 23, 1994. Lowell Witz identified his contribution to this proposal in a letter sent to the author received June 1,1994 .

${ }^{2}$ Cummings, Moon, and Witz, "Preliminary Proposal." 
2. Computer support Services for personalized mass mailing and materials distribution. ${ }^{1}$

Following these two basic services is mention of four problems that would be confronted by the proposal to It Is Written, including: (1) unsatisfactory telephone service, (2) delayed responses, (3) lack of evaluation, and (4) inadequate follow-up. The preliminary proposal was then organized according to a three-phase plan which was suggested by the officers of It Is Written for the sake of cost feasibility:

Phase I includes the Watts line telephone answering and follow-up services. Phase II includes packaging and shipping services. Phase III includes letter writing and receipting services. ${ }^{2}$

\section{Andrews University's unique capabilities identified.}

of the many advantages to the Adventist Church and related organizations which are pointed out in this 800 -number pilot project proposal, four stood out as offering "unique capabilities" with the developing ministry being located on the campus of Andrews University. These four capabilities included: ${ }^{3}$

1. A large pool of highly qualified student and student-spouse workers in seminary or other graduate education programs.

\footnotetext{
IIbid., see "Introduction."

${ }^{2}$ Ibid.

${ }^{3}$ Ibid., see "Advantages."
} 
2. Student personnel costs which may be as much as 50-75 percent lower for what would have to be paid elsewhere with full-time staff.

3. Students and spouses who are willing to work peculiar part-time schedules, which can readily accommodate the peaks and valleys of this type of work.

4. A soul-winning enterprise at Andrews which would educate many student ministers in how their future ministries can benefit from the outreach provided through media programs, which in turn will create an increased responsiveness to media program ministry when these students become full-time workers in the field.

\section{Proposal accepted by George Vandeman and the IIW}

board. The proposal was submitted as requested to the It Is Written Board and George Vandeman, speaker-director of the It Is Written telecast. Vandeman and the officers of Faith for Today then visited the Andrews campus, "at which time they conferred with the Institute and the computing center on the details of the proposal." ${ }^{1}$ Following this meeting, Vandeman voiced his definite interest in the program that this proposal had outlined and desired to see it enacted in association with Andrews University. ${ }^{2}$ Following a period of fund-raising, it was noted that:

\footnotetext{
${ }^{1}$ Introduction to "Highlights of the Andrews University 800 Number: Interest Identification and Follow-Up System," 1.

${ }^{2}$ Ibid.
} 
The 'It Is Written' team has been able to identify and solicit monies that will make it possible for them to pursue the 800 number, despite decisions that might be made by other entities of the church. Therefore, a meeting has been set for Wednesday, December 9, [1981], with the chief financial officer, Art Krogstad, and the field service director, Royce Williams. This meeting will serve to detail the steps that must be taken to make the system operational as it applies to the needs of It Is Written. ${ }^{1}$

Broader 800-Number Plan Presented to the General Conference of SDAs

Following the presentation of the proposal to It Is Written, the Institute of Church Ministry was invited to present its 800-number plan to the Faith Action Advance Committee of the General Conference, because:

The problem that Faith for Today faced was found to be a problem that was shared by all of the media groups in the church, and that is that the follow-up procedures, for ensuring that an individual who contacts the ministry is given the opportunity to respond to the gospel, are limited. ${ }^{2}$

Following a half-day session which addressed the issue of interest follow-up, it was decided that this plan was "superior to present procedures." A meeting was then scheduled for January of 1982 in Loma Linda, California, where:

The officers of the General Conference have asked that all of the media directors and speakers meet along with the circulation managers of the presses and the Institute of Church Ministry to explore the feasibility of establishing an 800

IIbid., 1-2.

${ }^{2}$ Ibid. , 1. 
number system at Andrews University that would serve the needs of all the above entities. ${ }^{1}$

NAD Leadership Support

Charles Bradford. Leading the North American

Division of Seventh-day Adventists as General Conference Vice-President for North America ${ }^{2}$ nearing the time of AIM's birth, Charles Bradford believed the NAD had a supportive role to play in trying to raise money and serve as a resource to help make AIM happen, especially because AIM could meet an important need at the local church level.

We had looked at ourselves as being equippers for ministry throughout the NAD, and this [AIM] was one avenue that we felt would be a "bell-ringer" and a "do-able."

"Hands-on" is what we are talking about, and those dear people in the pew, to facilitate their ministry, was the big point. If what we are doing here [at the NAD] does not facilitate what happens there at the local church, then we need to look again at what we are doing. So we thought that AIM filled this idea very well. It met what we felt was a great need. ${ }^{3}$

Robert Dale and the AIM name target. Working behind the scenes as one of the NAD editors for the Institute of Church Ministry's Administry, Robert Dale's resourcefulness was making an impact on the birth of AIM as well. Having recently moved to the North American Division offices to

${ }^{1}$ Ibid.

${ }^{2}$ Seventh-day Adventist Yearbook (Washington, DC: Review and Herald Publishing Association, 1982), 181.

1994.

${ }^{3}$ Charles Bradford, telephone interview with author, April 27, 
serve as administrative assistant to the vice-president for North America, ${ }^{1}$ Dale was delighted to see a long-time dream for something like AIM turning into reality.

While working with and assisting Bradford at the NAD, Dale regarded Adventist Information Ministry as being aimed at one important and particular target:

AIM is not just a shotgun but rather a bullet with its specific one-point mission, to develop the interests brought to AIM and develop them to fruition.

[Thus,] the primary objective for establishing AIM was to provide a follow-up for interests. This was the specific objective. ${ }^{2}$

\section{GC and union detractors silenced by AIM cheering}

squad. Commenting on his personal involvement with

Adventist Information Ministry's beginning, Bradford stated:

"I was just on the sidelines, encouraging them and cheering them on." ${ }^{3}$ From the perspective of encouraging timely follow-up as reported earlier in this chapter, Bradford, Dale, and a few other NAD leaders were discreetly applauding the birthing of this new ministry-based business for God. However, not everyone in leadership positions with the SDA church was on the cheering squad rooting for AIM. As revealed by one of AIM's supporters from his office at church headquarters, "when we started out with this

\footnotetext{
${ }^{1}$ SDA Yearbook, 1982, 181

${ }^{2}$ Dale, interview, April 27, 1994

${ }^{3}$ Bradford, interview, April 27, 1994.
} 
objective, we had many detractors who said this will never work. At the General Conference and Union levels it was pretty broad spread." ${ }^{1}$ But the leaders who believed a ministry like AIM would make a significant difference by expediting the follow-up of a person's spiritual interests generated through one of the church media sources, eventually did win the battle against their opposition. As Bradford stated:

I had a strong hope and desire to see every interest followed up. We wanted to collapse the time float, too much time, turn-around time, as they would say these days. We wanted to get to people while they were in the afterglow, as it were. The presentation is made, and almost before they can come down from the cloud some contact is there. ${ }^{2}$

Explained Cummings, "Bradford was particularly preaching the idea during this time that we have to follow through on the interests that the Lord gives us." In Des Cummings Jr.'s opinion, "this set a background" for a vitally important foundational basis for Adventist Information Ministry's birth. ${ }^{3}$

A Basement Building Beginning with World's Fair Prominence in 1982

With humble beginnings in a basement room of the administrative building on the Andrews University campus,

${ }^{1}$ Committee member \#52, telephone interview by author, April 27 and May 2, 1994 .

${ }^{2}$ Ibid.

${ }^{3}$ Cummings, interview, May 7, 1994. 
the birth of this new information ministry became recognizable in May of $1982^{1}$

It started slow and we did it down in the basement of the Administration Building. Once we got the permanent contracts going we moved it off the paper and pencil routine. . . Then as we got it to where it could be more viable we just had to build a certain number of booths and let it grow. ${ }^{2}$

In addition to the important "wider contract for the media" which came through in the spring of 1982, another significant contract for this budding information service developed as a result of the World's Fair that summer. ${ }^{3}$ Looking back at the event in November of 1982, the Adventist Review wrote:

Enthusiastic laymen took the initiative to establish a large SDA exhibit at the World's Fair in Knoxville, Tennessee. Tens of thousands of visitors to the fair this summer caught their first glimpse of what Adventism is all about. The special

Friendship Issue of the Adventist Review, distributed at the fair and across the nation, provides an in-depth look at the full scope and character of the church's mission to the world. ${ }^{4}$

Of these "tens of thousands" of World's Fair visitors, many contacted the newly established service at Andrews University for more information about Adventism. It

${ }^{1}$ For confirmation of the May 1982 date as the recognized and publicized beginning of AIM, see: Doug Tilstra, "800 Number Facilitates Follow-Up," Administry, Autumn 1982, 10; and Ronald Knott, "A Telephone Ministry for the Nation," Lake Union Herald, July 19, 1983, 6.

${ }^{2}$ Cummings, interview, May 7, 1994.

${ }^{3}$ Ibid.

"Ronald Knott, "Information Ministry Is Established at Andrews," Adventist Review, November 25, 1982, 12. 
was this large though temporary contract that especially gave "prominence and awareness" to the newly formed ministry named Adventist Information Service. ${ }^{1}$

\section{Publication of Early Developments}

\section{Adventist Information service}

A new telephone ministry. "It's called the

Adventist Information Service (A.I.S.) and is sponsored jointly by Andrews University and the North American Division." This is how the Seventh-day Adventist denomination's very first periodical article on the subject, "A New Telephone Ministry," by Ronald Knott of the public relations office at Andrews, introduced this new venture. ${ }^{2}$

Described in its simplest terms, A.I.S. relies on two basic elements: trained and friendly Andrews people on the telephone; and the massive information processing capabilities of the Andrews University Computing Center. ${ }^{3}$

\section{A result of studies conducted by ICM. This three-} page article, published May 25, 1982, by the Lake Union Herald, would be the first of dozens of articles bringing publicity to the new ministry. Published for SDA church members in the Great Lakes region of the United States, this article (with an edited version in the Adventist Review

\footnotetext{
${ }^{1}$ Cummings, interview, May 7, 1994.

${ }^{2}$ Ronald Knott, "A New Telephone Ministry," Lake Union Herald,
} May 25, 1982, 4 .

${ }^{3}$ Ibid. 
appearing November 25, 1982, for church members throughout North America) would link the early development of A.I.S. with the Institute of Church Ministry in this way:

Described informally as a telephone ministry, A.I.S. was developed during a period of two years as a result of studies conducted by the Institute of Church Ministry. Those studies reemphasized a basic principal of evangelism: Prompt response combined with the human warmth of person-to-person contact is the most effective way of bringing people to the truth.

The telephone provides the personal contact. The computer provides the prompt response. Andrews people, local pastors and dedicated laymen all provide the human warmth. ${ }^{1}$

\section{Initial GC funding brings a twofold benefit.}

Initial funding for the system has been provided by a $\$ 50,000$ appropriation from the General

Conference. According to Dr. Moon, that allocation covers start-up costs (purchasing computer terminals and installation of telephone lines), administrative and maintenance expenses, account servicing, training of staff and monthly telephone rental. ${ }^{2}$

With this new industry on campus, students would be able to earn tuition money and receive valuable experience in church service. Regarding this linking of student employment and evangelistic outreach, Moon said:

Andrews students will now participate in the ministry of the church in a way that has never been possible before. And I believe that as Adventist Information Service becomes a support to Faith Action Advance and the Thousand Days of Reaping, it may become the single largest source of employment for students at Andrews University. I can think of

\footnotetext{
IIbid., 5.

${ }^{2}$ Ibid.
} 
no better work we could offer than this active involvement in the ministry of the church. ${ }^{1}$

As the speaker and director of the It Is Written telecast, George Vandeman declared a similar thought by saying :

We are looking forward to working with A.I.S. I see this new ministry of the church as an invaluable tool in training our young ministers and their wives for soul-winning work. ${ }^{2}$

\section{Doug Tilstra's look at AIS's system of evaluation}

and follow-up. The second article published about Adventist Information Services came from the Institute of Church Ministry's own publication, Administry. Written by Doug Tilstra, a seminary student serving as the first "800 Number Follow-Up Director," Tilstra's article gave "a quick look at AIS's system of evaluation and follow-up": ${ }^{3}$

For the past five months (since May 1982) the Adventist Information Service (AIS) has been developing a system of interest evaluation and follow-up which promises to be one of the most effective and efficient methods ever utilized by the Seventh-day Adventist Church. ${ }^{4}$

The summer of 1982 was a busy time for the newly developed ministry of Adventist Information Service. During the "pioneering stages" as Tilstra referred to them, A.I.S. was handling interests from three sources: "The World's Fair

\footnotetext{
IIbid. , 6.

${ }^{2}$ Ibid.

${ }^{3}$ Tilstra, 10.

${ }^{4}$ Ibid.
} 
Project, It Is Written telecast, and the Friendship Issue of The Adventist Review. "1

By september 7 of that year, some 12,137 visitors to the World's Fair in Knoxville, Tennessee, had stopped by the SDA church's display booth and filled out a card requesting literature. Then, 115 individuals from that large number were classified as "top interests" for having expressed a personal desire for either a visit or a Bible study.

\section{Three-step follow-up approach of A.I.S. chaplains.}

Tilstra explained that once these interests were classified at A.I.S., the second step was to call the interested person and confirm his/her interest within seven days of the initial contact. Based on this phone call, when a visit or Bible study was determined by the A.I.S. chaplain to be appropriate, a pastor in the interest's local area was then contacted by phone in no more than three days and given the name and information about the confirmed interest being referred.

Within seven to ten days the third step emerged, with a phone call made to the pastor to inquire about how the visit or study went with the interested person. "The goal is that no more than fourteen days will lapse between the initial response of a person and local church

${ }^{1}$ Ibid. 
visitation," Tilstra wrote. ${ }^{1}$ In conclusion, he said:

"A.I.S. is still in developmental stages but is already showing signs of becoming a valuable resource tool for the local conference and church." ${ }^{2}$

A helpful name change. From the pacesetting May 25, 1982, Lake Union Herald article through the Administry account written on september 7 published in Autumn 1982, ${ }^{3}$ the name Adventist Information Service was exclusively utilized. However, when subsequent periodical articles later appeared in print in the autumn of 1982, the newly established Adventist Information Service was being referred to as Adventist Information Ministry. Craig Willis explained how the Adventist Information Service name resulted in the general public's misunderstanding of what the new telephone service was all about:

At first it was A.I.S., Adventist Information Service. We started using that name and promoting it, but the general public did not seem to understand what Adventist Information Service was. For example, we had numerous phone calls from people regarding the ferry schedule across Lake Michigan. We realized we had to do something that would convey we were a spiritual information source. So we changed the word service to ministry, and that is how it became Adventist Information Ministry. ${ }^{4}$

${ }^{1}$ Ibid.

${ }^{2}$ Ibid. , 11.

${ }^{3}$ In the Autumn 1982 published Administry, Tilstra wrote: "To date (September 7, 1982). . . " Ibid., 10.

${ }^{4}$ Craig Willis, telephone interview by author, May 2, 1984 . For written/printed confirmation of the name change: "Dubbed initially as 
Despite the publicized change of names noted in the Adventist Review and other periodicals in the fall of 1982, the name Adventist Information Service would still be used by the AIM staff for a period of time, at least through the winter of $1983 .^{1}$

\section{Adventist Information Ministry}

Twelve 800 -number Iines. In Focus magazine, the quarterly journal of Andrews University, the first report on AIM titled "Adventist Information Ministry Begun on Campus" occurred in the fall of 1982. It highlighted the number of phone lines and work stations while reporting:

The Adventist Information Ministry (AIM) operates twelve 800-number service telephone lines, allowing toll-free calls from individuals interested in finding out more about Adventism from anywhere in the continental United States.

In addition to having the incoming 800-service lines, four lines for outgoing calls make possible the vital follow-up aspect of the system. Individual work stations, built to accommodate the special telephone lines and computer access terminals have been installed.?

the Adventist Information Service (AIS), the last word was soon changed to "ministry" to convey the distinctive spiritual nature of the work done by the Andrews University group." Craig willis, "Adventist Information Ministry: The Denomination's Resource Center for Data Processing and Evangelism," Administry, Autumn 1983, 4.

${ }^{1}$ See Appendix $F$ for the Adventist information Service letterhead dated March 18, 1983, and for the Adventist Information Ministry letterhead dated March 31, 1983. While these dated letters illustrate how the AIS name was used for a number of months after the name change to AIM, they are not an attempt to establish the exact period of time for when the AIS name/letterhead was discontinued or precisely when the AIM name/letterhead usage began. 1982,2 .

2 "Adventist Information Ministry Begun on Campus," Focus, Fall 
Expansion while the phones keep ringing. A second article about AIM appearing in the Lake Union Herald was published five months after the first one, on October 26 , 1982. Reprinted from the Student Movement, the Andrews University student newspaper, this one-page presentation introduced three important new developments for AIM:

[1] There are plans for printing the [800-] number regularly in Adventist outreach literature. [2] AIM will be expanded to include catalog ordering of Adventist books and materials for people who do not have easy access to an Adventist Book Center. [3] Advertisements about the Adventist Church are being run in issues of the Reader's Digest west of the Mississippi River. ${ }^{1}$

Craig Willis, who began serving at A.I.S./AIM as "chaplain-supervisor of the answering service," reported that "on an average Sunday, Andrews students answer 100 to 300 calls." ${ }^{2}$ He further commented:

Fifteen students are employed in the requestprocessing aspect of the telephone ministry. A crew of 24 seminary students and under-graduate theology majors answer calls generated by It Is Written. In addition, another five seminarians are engaged in follow-up ministry.

Elder Willis says the phone lines are open seventeen hours a day, six days a week. A recorded answering service is used during off-hours.

A staff picture for the nation-wide phone ministry. After one year of official operation, it would be reported

${ }^{2}$ Linda Gill, "The Phones Keep Ringing at the Adventist Information Ministry," Lake Union Herald, October 26, 1982, 7.

${ }^{2}$ Ibid. 
in the summer of 1983 that Adventist Information Ministry "is growing by leaps and bounds."

Begun in May 1982 with a dozen students working in the basement of the Administration Building, the operation now employs 50 students, and plans are being made to move to more spacious facilities on campus. ${ }^{1}$

This periodical article, the third story on AIM by the Lake Union Herald, was the first to print a picture of the entire in-house staff working together. Located on the first page of this particular issue, the caption beneath the black-and-white photograph read:

Joanne Schneider, right, A.I.M. supervisor, discusses commercial billing procedures with, from left, Rebecca Lofthouse, supervisor's assistant; Craig Willis, A.I.M. Chaplain and follow-up coordinator, and Donna Todd, department secretary. ${ }^{2}$

This story described a number of new developments taking place at AIM. For one, Breath of Life telecast calls from people watching in North Carolina and Montana were now being handled. Second, Adventist Information Ministry was stocking a wide range of extra literature with titles not offered by It Is written for mailing to 800-line callers upon request. Third, the 800 -number was now being used to take orders for information about seminars and filling orders for "Spiritual Gifts Inventory" materials. ${ }^{3}$

\footnotetext{
${ }^{1}$ Knott, "A Telephone Ministry for the Nation," 6.

${ }^{2}$ Ibid.

${ }^{3}$ Ibid. , 7.
} 
While the above three services would continue and expand with the growth of Adventist Information Ministry, another development with immense proportions was begun at AIM but then transferred to the General Conference of Seventh-day Adventists:

A.I.M. has also begun working on a massive data processing project under contract with the General Conference. Denominational personal service records are being put on computer file.

To date, more than 56,000 records have been processed. Elder Willis says these represent the records of only a few of the health related institutions. Service records from educational, administrative and publishing organizations will come later. ${ }^{1}$

One year old and already a major resource center.

This summer marks the first anniversary of the Adventist Information Ministry located at Andrews University. Beginning with one TV station out of Atlanta from which the telephone ministry answered calls for It Is Written (IIW) and the computer processing of over 17,000 names for the World's Fair, AIM has grown into a major resource center for data processing and evangelism for the seventh-day Adventist church. ${ }^{2}$

Whereas AIM's phone service got started with just one Sunday morning call-in, Adventist Information Ministry was now operating seven days a week and twenty-four hours a day. In commemoration of this first year of service, Willis commented on the growth and expansion of AIM's services by writing :

\footnotetext{
${ }^{1}$ Ibid.

${ }^{2}$ Willis, "Adventist Information Ministry," 4.
} 
Multiple stations are now listed with AIM, and students may process upward of 600 calls on a weekend for "It Is Written" and "Breath of Life" programs. To date, operators have answered almost 14,000 calls from IIW viewers in all 50 states. More than 2,000 calls have been received from Breath of Life viewers in 43 states. Special runs by other of the church's media programs can bring in a considerable number of calls. Such was the case when "Faith For Today" used AIM to handle nearly 3,000 calls in one week for a recent program on "stress." 1

\section{Craig Willis looked back at a bright future.}

Surveying the spiritual bridge Adventist Information

Ministry had built between the media programs and the local church over the first year of official operation, Craig Willis, AIM follow-up coordinator, was moved to pen these words of gratitude and hope:

The Lord has truly blessed a simple idea and developed it into a major source of data processing and evangelism coordination for the church. The productivity and efficiency of the church has grown under this experiment. And the future is even brighter. ${ }^{2}$

${ }^{1}$ Ibid.

${ }^{2}$ Ibid., 5 . 
CHAPTER FOUR

CHAPLAINS

\section{Development of the A.I.S./AIM Chaplain: Some Historical Perspective}

Out of the foundational milieu reported in chapter 3 and resounding need for prompt follow-up of media evangelism interests, Adventist Information Service, re-named Adventist Information Ministry, came into being. The stage was now set for the entry, naming, and development of an employee known as the chaplain.

The Chaplain's Name

Within the first few months of official operation, Adventist Information Service began utilizing chaplains. Consideration was given to the most appropriate label to use for this A.I.S. employee, with the name "chaplain" selected because

the term chaplain was more neutral than some denominational nomenclatures like rabbi or bishop. A chaplain is easily understood as being a clergyman, and yet it has kind of an institutional concept that frees a person from being tied to any particular denomination. ${ }^{2}$

${ }^{1}$ See Tilstra, 10.

${ }^{2}$ Willis, interview, May 2, 1994. 
With Adventist Information Service especially created to serve as a kind of bridge between media interests and a saving relationship with Jesus Christ through the Seventh-day Adventist Church, the choice of the chaplain name for the A.I.S. employee appears to have been a wise decision. It was understood that callers responding to Adventist media program offers came from a wide spectrum of religions and denominations in North America. As Willis indicated, A.I.S. pioneers believed the name "chaplain" could convey a neutral impartiality that would help reduce the uncertainty and possible alienation callers might have toward a denomination or religion unknown to them.

In a church climate of renewed evangelistic expectation, A.I.S. chaplains would need a gift of chaplainlike tact to help accomplish their delicate work of following up on media interests. It was hoped the term "chaplain" would further underscore the nature of their seed-sowing ministry created to assist rather than compete with other ministries and ministers for the grand mission of soul-winning within the SDA church. Understanding how the chaplain name can in fact help ease communication with potentially suspicious souls and fragile evangelistic issues, a retired military chaplain and former chaplain at Adventist Information Ministry wrote:

Chaplains . . are seed planters. A majority of the people to whom they witness are not ready for baptism in three, six, or even twelve weeks. Their clientele are very largely non-Adventist, and those 
who are professionals are not given to hasty decisions based on intense emotion. Chaplains plant the seed and nourish it for whatever time they are given and pray that someone, somewhere will perform the baptism. [However,] it should not sound as though chaplains never win souls to Christ or are not evangelistically enthusiastic. Bible studies - . are part and parcel of the chaplain's ministry. Baptisms follow in due course. ${ }^{1}$

Seminary Students Selected to

Serve for the Developing Role

How did the role of the Adventist Information

Service/Adventist Information Ministry chaplain develop? In response to the first half of question 7 asked during the project interview, Bob Moon suggested the role of the chaplain initially "came out of a need with people asking questions." As callers began to make inquiry about the various spiritual and theological questions they had on their minds, it was realized that not all of the students employed by A.I.S. were comfortable or in some cases able to answer the questions posed by the 800-number callers. ${ }^{2}$

With A.I.S. serving as a training ground for students interested in becoming involved in church outreach, Robert Dale noted that employees were needed who could "transmit to the students working at AIM" their experience and knowledge of working with people on a spiritual level in

'James J. North, Jr., "Chaplaincy Ministries: The Development and Implementation of a Course in Specialized Ministries as Vehicles for Seventh-day Adventist Self-Understanding and Expression of Mission"

(D.Min. Project, Andrews University, 1988), 50.

'Moon, interview, April 28, 1994. 
the church. Furthermore, Dale pointed out, a need for employees who were "very people-centered and who understood the church and church structure" became apparent in light of the referral and follow-up work that had begun.'

With this need for specialization at Adventist Information Service having risen, a division of labor developed with students primarily from the seminary caring for the referral and follow-up of people with a higher level of spiritual interest, while students from other schools on the university campus handled the frontline operations of coupon and phone requests along with computer data entry.

\section{Setting Initial objectives}

Responding to the second half of interview question 7 which sought to identify specifically who set forth the chaplain's initial goals and objectives, Dale indicated the most involved leaders of AIM's executive steering committee made their contribution. ${ }^{2}$ Under the direction of Des Cummings, Jr., Doug Tilstra, a seminary student at Andrews University who served as the first A.I.S. chaplain and 800number follow-up director, initially put together the chaplain's three-step "system of interest evaluation and follow-up," while Lowell Witz provided computer-programming

${ }^{1}$ Dale, interview, April 27, 1994.

2 "Bob Moon, Gary Patterson, and I were the ones who established the role of the AIM chaplain and set their initial goals and objectives." Dale, interview, April 27, 1994. 
support for the system. ' Then, according to Cummings, a few months later in the summer/fall of 1982 "when Craig Willis came on board, he was the key person to operationalize the chaplain's ministry and its development." ${ }^{2}$ For the fifteen and a half years that ensued until his death, the scope of the chaplain's work was greatly expanded under the leadership of Willis who put his heart and soul in the mission-centered work at Adventist Information Ministry. ${ }^{3}$

\section{Description of the AIM Chaplain's Role: \\ A More Recent Perspective}

More than fifty chaplains have served the A.I.S./AIM organization during its first dozen years of operation. ${ }^{4}$ Each individual chaplain and collective chaplain team has made their "indelible mark," said Willis, in contributing to the development of a chaplain's department that encouraged employee recommendations and allowed for beneficial modifications to be implemented by each chaplain group. In a work environment where team innovation was promoted, each

${ }^{1}$ Tilstra, 10 .

Doug Tilstra, telephone interview by author, september 11, 1994.

"As far as the ministry of follow-up I did a good share of that. . . and Lowell [Witz] really operationalized that." Cummings, interview, May 5, 1994.

${ }^{2}$ Cummings, interview, May 7, 1994 .

${ }^{3}$ Craig Willis died of cancer on February 7, 1998.

${ }^{4}$ The number of chaplains was derived from a search amongst AIM employee files for former AIM chaplains, by Tami Faudi, AIM secretary, February 1994 . 
chaplain had "a special companionship with fellow chaplains in learning and practicing new ways of handling media interests." 1

The particular emphasis of the manifold media programs, the varying needs of the numerous people served, plus the changing and expanding technology at AIM have all impacted the chaplain's work at Adventist Information Ministry. Despite the varying changes and unique expressions characterizing each AIM chaplain's team, some basic functions have spanned the course of time for the chaplains at Adventist Information Ministry. ${ }^{2}$ In more recent years, the AIM chaplain's fundamental responsibilities have been primarily understood as follows.

\section{AIM Chaplain's Fundamental}

\section{Responsibilities}

The basic functions of the AIM chaplain can be organized into three categories comprised of two related functions each, which are: (1) referral and follow-up, (2) prayer-intercession and counseling, and (3) meetings and administrative duties. These half dozen fundamental responsibilities associated with the AIM chaplain's work are described in Table 5, which follows and reflects a August 1991 .

${ }^{1}$ Craig Willis, "Introduction" to "Steps in Chaplain Training,"

${ }^{2}$ See "Doug Tilstra's look at AIS's system of evaluation and follow-up" in chapter 3 of the dissertation for some historical perspective on basic similarities with the AIM chaplain's role in later years. 
TABLE 5

FUNDAMENTAL RESPONSIBILITIES OF THE AIM CHAPLAIN

\begin{tabular}{|c|c|c|}
\hline Function & & Description \\
\hline $\begin{array}{l}\text { Referral and } \\
\text { Follow-Up }\end{array}$ & & $\begin{array}{l}\text { Make confirmation and referral calls } \\
\text { as soon as possible upon reception } \\
\text { of the request; record information } \\
\text { on confirmation and referral notes. } \\
\text { Nurture each referral in assigned } \\
\text { territory through systematic follow- } \\
\text { up calls until a suitable conclusion } \\
\text { has been reached; record information } \\
\text { on interest update sheet. }\end{array}$ \\
\hline $\begin{array}{l}\text { Counseling } \\
\text { and Prayer- } \\
\text { Intercession }\end{array}$ & 1 . & $\begin{array}{l}\text { Prayerfully respond to callers' } \\
\text { needs and answer their questions } \\
\text { from a biblical perspective. } \\
\text { Utilize a conferral report for all } \\
\text { chaplains' calls and its disclaimer } \\
\text { statement whenever appropriate. } \\
\text { seek for balance between benevolence } \\
\text { and prudence regarding length and } \\
\text { frequency of chaplains' calls. }\end{array}$ \\
\hline $\begin{array}{l}\text { Meetings and } \\
\text { Administrative }\end{array}$ & 2 & $\begin{array}{l}\text { Attend scheduled chaplains meetings. } \\
\text { Submit and follow a monthly schedule } \\
\text { of availability for chaplains' calls } \\
\text { and other chaplains' work. } \\
\text { Keep daily inventory of calls and } \\
\text { letters on the verification list. } \\
\text { Maintain brief documentation and } \\
\text { orderly files of calls and letters. } \\
\text { Write success stories on interests' } \\
\text { significant progress and baptisms. }\end{array}$ \\
\hline
\end{tabular}


perspective stemming from the author's work experience at Adventist Information Ministry from the spring of 1992 through the summer of 1994 .

These six integral responsibilities have generally been shared equally among the AIM chaplain teams that are formed. Depending upon the current work load and level of training, aptitude, and personal interests of each chaplain in a given team, these basic functions have at times been divided among a few select chaplains. Such divisions have been signaled by a chaplain title which matched the particular role being emphasized or entirely executed by that particular chaplain, such as: referral chaplain, follow-up chaplain, prayer-ministry chaplain, etc.

AIM Chaplain's Unilateral Responsibilities

Letter-writing chaplain and bilingual chaplain. Two other chaplain titles have carried responsibilities that are not equally shared among the group, including: (1) the letter-writing chaplain who handles letter and coupon-based questions dealing with theological and personal problems, requests for services AIM does not provide, and special literature needs; and (2) the bilingual chaplain who cares for the fundamental and letter-writing responsibilities associated with Hispanic-speaking interests. Given the similarities of the two roles, the letter-writing and bilingual chaplain positions are often combined. 
The senior chaplain. A third chaplain title with another set of unilateral responsibilities is that of the senior chaplain. This position is usually filled by a more seasoned minister who is preferably ordained. Like other AIM chaplains, the senior chaplain is also enrolled as a full-time graduate student at Andrews University, with a doctoral student being preferred.

The senior chaplain participates as needed in the basic functions of the AIM chaplain, with primary responsibility directed toward assisting the associate director/follow-up coordinator with the instruction and coordination of: (1) AIM chaplains in their fundamental responsibilities; (2) the work of the chaplain's secretarial assistant; and (3) seminarians fulfilling their NADEI (North American Division Evangelism Institute) requirements at AIM.

\section{Perceptions about the AIM Chaplain's Role: Interview Response Analysis and Evaluations}

A shift in the dissertation occurs here in the unveiling of multiple survey findings discovered for the AIM chaplain's role, with a deepening penetration in the analysis of interviewee response and their evaluations occurring through the remainder of this fourth chapter. We glance first at surveyed perceptions about job training, a chaplain's manual, accountability, and evaluation for the AIM chaplain, followed by a look at interviewee's remarks for the senior chaplain's role. The remainder of the 
chapter then delves into more extensive interview results and understandings associated with the half dozen principal components of the AIM chaplain's role.

Job Training, Chaplain's Manual, Accountability, and Evaluation

Question 16: Chaplains' evaluation of job training. The opening question for section III in the interview instrument asked, "How would you evaluate the job training that AIM chaplains receive?" The chaplains answering this question of the survey numbered $84.6 \%$. Aside from a few answers like "I don't remember" and "I didn't receive any," ${ }^{2}$ there were a couple of chaplains who expressed totally positive comments about their training with statements such as, "It was very good when I was there." ${ }^{3}$ An equal number viewed their chaplaincy training at AIM as totally negative, proclaiming that "the phone screening was neither logical nor humane." ${ }^{4}$ Three chaplains gave their training a mixed review, including one who believed the "coordinator did his best to help prepare us, but most learned by experience." ${ }^{5}$

\footnotetext{
${ }^{1}$ Chaplain \#19, telephone interview by author, May 4, 1994.

${ }^{2}$ Chaplain \#14, telephone interview by author, April 25, 1994.

${ }^{3}$ Chaplain \#18, telephone interview by author, May 3, 1994.

${ }^{4}$ Chaplain \#34, telephone interview by author, April 29, 1994.

${ }^{5}$ Chaplain \#31, telephone interview by author, May 1, 1994.
} 
The remaining responses to the $16^{\text {th }}$ interview question about chaplains' job training could be placed in one of the following two arenas. One of these camps of evaluatory comments (27.2\% of the total) associated the training they received as AIM chaplains directly with chaplains' meetings. Reflections of the completely positive comments in this meetings-centered group of replies included this testimony, "AIM did a very good job with training, how to deal with phone calls, referrals and computer use. Weekly chaplains' meetings were a type of ongoing training, helpful for discussing problems and methods." ${ }^{1}$ slightly more mixed reviews included remarks such as "Training was brief at times. Later it became better with chaplains' meetings including verbatims which really helped a lot on how I could improve, and when we identified our spiritual gifts in an optional chaplains' meeting." 2 Overall, it could be said that the chaplains who associated evaluation of their training at AIM with their chaplains' meetings seemed to feel the "chaplains' training was basic and sufficient to perform the job, though more material in cases was needed. Some meetings were helpful and others were not. ${ }^{3}$

${ }^{1}$ Chaplain \#12, telephone interview by author, May 3, 1994.

${ }^{2}$ Chaplain \#41, telephone interview by author, April 29, 1994.

${ }^{3}$ Chaplain \#40, telephone interview by author, April 29, 1994. 
On the other hand, the second group (also 27.2\%) cited specific improvements needed for training the AIM chaplain. A sampling of the remarks falling into this category would include: "I received good training up to the point of phone work as a chaplain, but there was no modeling by chaplains and listening in as was done on the operations side." ${ }^{1}$ Another chaplain said, "The majority of the training was good, particularly in the area of data entry and referrals. Otherwise, the chaplains training was not as in-depth as possible, and improvements were needed in ways to upgrade and move people into the church setting." 2

Question 16: AIM staff viewpoint. Three members of the Adventist Information Ministry staff offered evaluation comments for the job training AIM chaplains received. Said one, "I'm not too familiar with the chaplains' training procedures, but it appears to be a good training given the finished product I see." ${ }^{3}$ Upon hearing the question another staff person replied, "That is probably best asked of others. A 2-3 page sheet titled 'Steps in Chaplain Training' outlines the training. A tutorial approach is used. Some videos have been prepared to give tips based on the work exiting chaplains have done which new chaplains may

\footnotetext{
${ }^{1}$ Chaplain \#28, telephone interview by author, April 29, 1994.

${ }^{2}$ Chaplain \#43, telephone interview by author, April 28, 1994.

${ }^{3}$ Staff \#85, telephone interview by author, April 25, 1994.
} 
learn from." A final AIM staff member said, "There wasn't much training in the beginning years. Now there is more with uniformity. Chaplains' meetings provide extra training input. Training is much improved now, though there needs to be more interaction between chaplains and phone operators after the initial training." ${ }^{2}$

\section{Question 17: Chaplains' perspective on a chaplain's}

manual. Twenty-five of the interviewed chaplains expressed their thoughts for the following inquiry, "To what extent would a comprehensive, current AIM chaplains manual be useful as a sourcebook for training new AIM chaplains? And as a reference for more seasoned AIM chaplains?" Only two individuals answered in the negative or neutral, with one indicating it was "probably not needed" ${ }^{3}$ and the other responding "I don't know." ${ }^{4}$

Of the remaining $92 \%$ who stated such a sourcebook would be beneficial, roughly one-third of the respondents said it would be "helpful if. . " Here is a closer look at their responses. The group of somewhat dubious chaplains thought along the lines of this chaplain who believed such a printed reference would be "well worth it if not kept too

\footnotetext{
${ }^{1}$ Staff \#88, telephone interview by author, May 2-4, 1994.

${ }^{2}$ Staff \#84, telephone interview by author, April 29, 1994.

${ }^{3}$ Chaplain \#48, telephone interview by author, April 27, 1994.

${ }^{4}$ Chaplain \#31, telephone interview by author, May 1, 1994.
} 
big. The two large red resource binders ${ }^{1}$ were so massive" that they were unwieldy." "Helpful if not too heavy with brief suggestions and examples" ${ }^{3}$ was another chaplain's comment reflective of this same viewpoint. A few other chaplains felt a manual "could be helpful, but not when it comes to giving actual guidance which requires something too diversified and individualized. A book with pat answers won't do." 4 Thus it was expressed, "if alongside with someone, a manual would be helpful." But like the previous chaplain's response, this same chaplain made it clear that it could "not [satisfactorily] replace somebody. Having Craig Willis around to train and define was key." ${ }^{5}$ While another chaplain indicated "it would help a lot," he also expressed serious doubts about whether it could successfully be done, stating, "I don't know how all that could be put together and be manageable." ${ }^{6}$ In sum, a significant number of chaplains believed a chaplain's manual would be helpful

'These two red-colored 3-ring chaplains' resource binders were filled with articles pertaining to various aspects of the AIM chaplains' work. They had become outdated and bulky and remained incomplete for the purpose of providing a comprehensive, current, and manageable manual.

\footnotetext{
${ }^{2}$ Chaplain \#28, telephone interview by author, April 29, 1994.

${ }^{3}$ Chaplain \#43, telephone interview by author, April 28, 1994.

${ }^{4}$ Chaplain \#33, telephone interview by author, May 2, 1994.

${ }^{5}$ Chaplain \#12, telephone interview by author, May 3, 1994.

${ }^{6}$ Chaplain \#18, telephone interview by author, May 3, 1994.
} 
if all the material that was needed for it could somehow be squeezed into an appropriately sized and workable format.

Question 17: Staff response. Of the three AIM staff members who gave input for this interview question, two were in favor of a chaplain's manual and one was reluctant. One of the supporters felt "it was an excellent idea to have a training manual in writing, especially given the high chaplain turnover as students." 1 The other staff member believed "it would be very valuable, because we have so many procedures as with any job that is multi-faceted. I would welcome this were I a new chaplain." ${ }^{2}$ The third staff member indicated "it would be helpful. However, because each chaplain and chaplain team make their indelible mark, it would quickly become outdated due to this and computer changes that are and will take place." ${ }^{3}$

\section{Question 18: Chaplains' comments on accountability.} Of the surveyed chaplains, $92.3 \%$ answered this inquiry. Seven of them (29.1\%) believed an assortment of paper documents used in their work department supplied the source of their accountability. As stated by one chaplain, accountability occurred "through forms which had to be

\footnotetext{
${ }^{1}$ Staff \#84, telephone interview by author, April 29, 1994.

${ }^{2}$ Staff \#85, telephone interview by author, April 25, 1994.

${ }^{3}$ Staff \#88, telephone interview by author, May 2-4, 1994.
} 
filled out." 1 For others, specific documents were named and explained, such as "time sheets logging work activities," ${ }^{2}$ "the accepting calls schedule which could be compared with other chaplains' schedules . . . and verification list charts which noted who and how many have been called." ${ }^{3}$ Another chaplain similarly stated, "Outgoing phone logs and keeping referral bins up to date" are what helped us be accountable. ${ }^{4}$

A few from the group who believed their accountability was in some way connected to paper documentation were more dubious. For example, "beyond the reports of what we did during the week, I don't know. We were operating under an empowering mode: Here's your job, go do it." ${ }^{5}$ Another chaplain identified "keeping a time log sheet and record of calls" as a form of accountability, but then stated, "otherwise it did not seem like a lot of accountability or any discussion of it took place." ${ }^{6}$

Beyond the documentation statements, two registered their belief that there "didn't seem to be much" of it for

${ }^{1}$ Chaplain \#47, telephone interview by author, May 2, 1994.

${ }^{2}$ Chaplain \#29, telephone interview by author, May 3, 1994.

${ }^{3}$ Chaplain \#46, telephone interview by author, April 27, 1994.

${ }^{4}$ Chaplain \#26, telephone interview by author, April 25, 1994.

${ }^{5}$ Chaplain \#43, telephone interview by author, April $28,1994$.

${ }^{6}$ Chaplain \#40, telephone interview by author, April 29, 1994.

${ }^{7}$ Chaplain \#31, telephone interview by author, May 1, 1994. 
any AIM chaplain, and that there was "no real system of accountability when I was there." think the chaplains are held accountable. The coordinator is more an administrator who was often busy. . . More accountability was needed." ${ }^{2}$

In conjunction with the last chaplain's assertion, $25.0 \%$ of the chaplains responding to this $18^{\text {th }}$ question associated part of the follow-up coordinator's role with holding the chaplains accountable. "We were held accountable directly to Craig Willis, and his secretary also helped. He would ask us if we were doing such and such." ${ }^{3}$ Said another, "The coordinator nudged us at times," and then added, "despite the mountain of follow-up to tackle, we needed more accountability here." Additional ways in which the follow-up coordinator sought to biring accountability to the chaplains were recognized, as when "Craig checked on names that were followed up, " or by chaplains "having to write things down which the coordinator would review." 6 "As I recall, someone checked to see if contacts were made in an appropriate amount of time. The supervisor also listened in

\footnotetext{
${ }^{1}$ Chaplain \#25, telephone interview by author, May 3, 1994.

${ }^{2}$ Chaplain \#41, telephone interview by author, April 29, 1994.

${ }^{3}$ Chaplain \#12, telephone interview by author, May 3, 1994.

${ }^{4}$ Chaplain \#35, telephone interview by author, April 25, 1994.

${ }^{5}$ Chaplain \#15, telephone interview by author, April 25, 1994.

${ }^{6}$ Chaplain \#42, telephone interview by author, May 2, 1994.
} 
occasionally." ${ }^{1}$ One other chaplain felt that accountability was "mainly verbal through the coordinator, i.e., we need more success stories given in a pep rally sort of way." ${ }^{2}$

Four AIM chaplains linked accountability for themselves with their "weekly meetings and reports given at the meetings." ${ }^{3}$ Three of these four also felt that "accountability was not as prominent as it could have been." ${ }^{4}$ Said one chaplain with regard to accountability for their work at AIM, there was "none, other then chaplains' meetings or when a problem you contributed to developed. There could have been more accountability." ${ }^{5}$ only one chaplain remembered a "senior chaplain who would take time to go through paperwork and monitor the flow of work. " 6 As a final chaplain put it, there was "not a lot of accountability other than God and our own conscience." 7

Question 18: Staff response. Of the three AIM staff members who replied to this question, one member felt that the chaplain's accountability occurred "through the log

\footnotetext{
${ }^{1}$ Chaplain \#33, telephone interview by author, May 2, 1994.

${ }^{2}$ Chaplain \#44, telephone interview by author, May 1, 1994.

${ }^{3}$ Chaplain \#18, telephone interview by author, April 25, 1994.

${ }^{4}$ Chaplain \#23, telephone interview by author, April 26, 1994.

${ }^{5}$ Chaplain \#32, telephone interview by author, May 2, 1994.

${ }^{6}$ Chaplain \#11, telephone interview by author, May 1, 1994.

${ }^{7}$ Chaplain \#14, telephone interview by author, April 25, 1994.
} 
sheets, which is a chart that describes what they are doing with their time which is seen by the director, follow-up coordinator, and business manager." ${ }^{1}$ Another believed that accountability took place "through meetings" and "the confirmation and referral notes report which is seen by the senior chaplain and follow-up coordinator." ${ }^{2}$ Cited a third staff member, "the chaplain's time is looked at. If there is a problem, the senior chaplain shares the difficulties with the follow-up coordinator. If major discipline is involved, the director would become involved also." 3

\section{Question 18: Steering committee reply. From the} perspective of the AIM committee only two interviewees made remarks directed to the 18 th question. One said with regard to accountability for the chaplain at Adventist Information Ministry, "I don't know of anything, but a complaint usually surfaces." 4 The other committee member commented, "We have not had a great deal of careful review outside of Bob Moon's input. " 5

\footnotetext{
${ }^{1}$ Staff \#84, telephone interview by author, April 29, 1994.

${ }^{2}$ Staff \#85, telephone interview by author, April 25, 1994.

${ }^{3}$ Staff \#88, telephone interview by author, May 2-4, 1994.

${ }^{4}$ Committee \#57, telephone interview by author, May 3, 1994.

${ }^{5}$ Committee \#56, telephone interview by author, May 2, 1994.
} 
Question 19: Evaluation within the chaplain's

department. Similar to the $18^{\text {th }}$ question but with an attempt to investigate the concept of evaluation within the chaplain's department more specifically, the $19^{\text {th }}$ question claimed fewer responses with a total of nineteen chaplains answering. Given this question's similarity to the $18^{\text {th }}$ question, it appeared to border on prolixity for some of the interviewees.

Briefly, four chaplains could not remember if any evaluation had transpired. Another four basically stated "no" and "in a formal sense, none." 2 An additional seven chaplains answering this question thought they had not been evaluated formally but had been informally. Two chaplains within this domain said something similar to "not in an official way. However, one of the best things that ever happened for me unofficially was when three chaplains met for an hour at the end of our tenure and affirmed and critiqued each other." ${ }^{3}$

One chaplain stated unequivocally that he had undergone a process of evaluation during his tenure at AIM. He said, "Yes, Craig reviewed my work from time to time. There was a closure conference at the end of my employment

\footnotetext{
${ }^{1}$ Chaplain \#28, telephone interview by author, April 29, 1994.

${ }^{2}$ Chaplain \#15, telephone interview by author, April 25, 1994.

${ }^{3}$ Chaplain \#32, telephone interview by author, May 2, 1994.
} 
with AIM." 1 For the two AIM staff members replying to this question about evaluation, one proclaimed that they were "not aware of such"" and the other said, "I think it would be helpful." ${ }^{3}$

Perceptions about the Senior Chaplain's Role

Question 32: Chaplains' perspective. Question 32 asked interviewees to identify their understanding of the role of the AIM senior chaplain. Among the twenty-three chaplains who responded to this question, two were confused about the person serving in this role and asked, "Was this Craig Willis?" Another two chaplain interviewees indicated they did not know the answer to the question because they "didn't have that much contact with the AIM senior chaplain" 5 and "there was no such chaplain when I was there. " 6

${ }^{1}$ Chaplain \#26, telephone interview by author, April 25, 1994.

${ }^{2}$ Staff \#85, telephone interview by author, April 25, 1994.

${ }^{3}$ Staff \#84, telephone interview by author, April 29, 1994.

${ }^{4}$ Chaplain \#12, telephone interview by author, May 3, 1994, and Chaplain \#19, telephone interview by author, May 4, 1994. Craig Willis held the combined title of associate director/follow-up coordinator for much of his tenure at AIM and served solely as the follow-up coordinator during his earlier years. While willis was referred to as chaplain supervisor when his employment with Adventist Information Service began (see Appendix F), he never worked under the title of senior chaplain at either A.I.S. or AIM according to the author's knowledge.

${ }^{5}$ Chaplain \#33, telephone interview by author, May 2, 1994.

${ }^{6}$ Chaplain \#48, telephone interview by author, April 27, 1994. 
The majority of chaplains who answered question 32 (82.6\%) had clear and uniform opinions about the senior chaplain's role which by and large aligned themselves with the primary responsibilities previously outlined. As one interviewee described the office, the senior chaplain had "a leadership role in helping to deal with the overall operation of chaplains' work," and then added, "a chaplain to the chaplains." ${ }^{1}$ Said another, not only should the senior chaplain have "more experience in the field and greater experiential knowledge," but he should also be "a vision setter and goal setter who can figure out a better or simpler way to do the chaplain's work."

\section{Question 32: Committee and staff perspective.}

Only one AIM executive steering committee member answered question 32. His understanding of the role of the senior chaplain at AIM was "to act on behalf of the follow-up coordinator when he is not present, depending on the maturity of the senior chaplain who works primarily with the chaplains and not the clients." ${ }^{3}$ All four of the AIM staff who were surveyed responded to this question, with the first of these interviewees proclaiming that the senior chaplain is "a chaplain's chaplain who deals with supervision and

\footnotetext{
${ }^{1}$ Chaplain \#28, telephone interview by author, April 29, 1994.

${ }^{2}$ Chaplain \#46, telephone interview by author, April 27, 1994.

${ }^{3}$ Committee \#55, telephone interview by author, April 28, 1994.
} 
leads out in chaplain's meetings." ${ }^{1}$ A second member of this group noted the senior chaplain "has more responsibility for coordinating the chaplains' work." ${ }^{2}$ The third staff person pointed out that "senior chaplains are usually ordained persons who are still in a training program as doctoral students. They communicate with the follow-up coordinator, assist in designing follow-up programs, and draw up agendas for chaplains' meetings." ${ }^{3}$ As summed up by the final staff member interviewed, the senior chaplain "coordinates the rest of the chaplains. He is more of a peer who can assess their needs as students, as well as a family man who can identify and empathize. He is a general overseer of the chaplain's work who can help when the follow-up coordinator is gone. 14

Question 33: Chaplains' perspective on improving the senior chaplain's role. Are there areas that you see where the senior chaplain's role can be improved? This was the gist of the $33^{\text {rd }}$ question to which fifteen chaplains replied. Three of these interviewees stated that they could not offer any suggestions for improvement of this role, with one commenting that they had "not seen a job description"

\footnotetext{
'Staff \#85, telephone interview by author, April 25, 1994.

${ }^{2}$ Staff \#86, telephone interview by author, April 28, 1994.

${ }^{3}$ Staff \#88, telephone interview by author, May 2-4, 1994.

${ }^{4}$ Staff \#84, telephone interview by author, April 29, 1994.
} 
and thus were "at a loss to know what to expect." ${ }^{1}$ Another indicated "each person will do it in his own individual way," ${ }^{2}$ while a third chaplain expressed a similar thought by stating, "Each senior chaplain brings his own strengths." ${ }^{3}$ An expanded version of what these last two chaplains were saying in relation to improving the senior chaplain's role came from an AIM staff member who commented:

I suppose it depends upon the senior chaplain. Each chaplain has their own particular skills. . . . For example, I can remember a single fellow who had a great burden for single's ministry. He was able to organize a lot of material for that and help these people. . . Others have been really good in prison ministry. . . . So, the way they could improve it depends upon their emphasis and what that senior chaplain feels is his particular burden. Obviously, if it is his burden he throws his heart into it.

For the chaplains who were able to articulate a substantive reply to question 33, most of the opinions about improving the senior chaplain's role tended to gather around a wish for "more" of something. "Give more guidance, "5 "be more available, "6 "communicate more via voice mail" and

${ }^{1}$ Chaplain \#11, telephone interview by author, May 1, 1994 .

${ }^{2}$ Chaplain \#14, telephone interview by author, April 25, 1994.

${ }^{3}$ Chaplain \#23, telephone interview by author, April 26, 1994.

${ }^{4}$ Staff \#88, telephone interview by author, May 3, 1994.

${ }^{5}$ Chaplain \#19, telephone interview by author, May 4, 1994.

${ }^{6}$ Chaplain \#26, telephone interview by author, April 25, 1994.

${ }^{7}$ Chaplain \#29, telephone interview by author, May 3, 1994. 
receive "25-50\% more pay" ${ }^{1}$ are illustrative of their wish list for the senior chaplain. Four chaplains suggested the senior chaplain spend less time with administrative tasks, with one instance citing this was needed for the purpose of "being more involved as a spiritual leader to chaplains and staff." ${ }^{2}$ A similar suggestion invited the senior chaplain to "minister more to AIM workers." ${ }^{3}$ Another interviewee noted, "With more administrative assistance. . . they could concentrate on prayer warfare, improvements, etc." 4

\section{A final group of suggestions by the chaplain} interviewees invited the senior chaplain "to share more of what he sees in how each chaplain could function better and use time more wisely." ${ }^{5}$ This was similarly described as "working with each chaplain regarding improvement and evaluation as a check and balance system." ${ }^{6} \mathrm{~A}$ closing recommendation made a bid for the senior chaplain to "further develop chaplains' counseling."7

\footnotetext{
${ }^{1}$ Chaplain \#28, telephone interview by author, April 29, 1994.

${ }^{2}$ Chaplain \#25, telephone interview by author, May 3, 1994.

${ }^{3}$ Chaplain \#43, telephone interview by author, April 28, 1994.

${ }^{4}$ Chaplain \#44, telephone interview by author, May 1, 1994.

${ }^{5}$ Chaplain \#46, telephone interview by author, April 27, 1994.

${ }^{6}$ Chaplain \#32, telephone interview by author, May 2, 1994.

${ }^{7}$ Chaplain \#15, telephone interview by author, Apri1 25, 1994.
} 


\section{Question 33: Staff's perspective. From the}

viewpoint of the AIM staff, one member wished the senior chaplain would "urge chaplains to mingle and interact more with AIM student workers. With the physical layout of the office there is less socializing going on as compared with the old physical plant which did not have inside walls or office rooms." ${ }^{1}$ Another staff member felt the senior chaplain's role should be made into "a full-time position," given the extent of "responsibility for coordinating the chaplains' work" coupled with "going the second mile," as displayed by one senior chaplain during a demanding time at AIM. ${ }^{2}$

Questions 24 and 26: Chaplains'

Ranking of Their Fundamental Functions

In the third section of the interview instrument which handled the bulk of questions dealing with AIM chaplains, question 24 sought to measure perceptions of interviewees with regard to six basic functions of the AIM chaplain according to the importance of each task. The question was read to each interviewee and the six functions comprising the AIM chaplain's responsibilities were all identified as they appear in question 24 of the interview instrument. Interviewees were then asked to rank these

\footnotetext{
${ }^{1}$ Staff \#84, telephone interview by author, April 29, 1994.

${ }^{2}$ Staff \#86, telephone interview by author, April 25, 1994.
} 
functions in order of their importance, with a ranking of 1 considered most important, and 6 signifying least important.

Table 6 introduction. Scores from the twenty-four chaplains who responded to question 24 were then tallied and averaged for the six areas of chaplain's service at AIM. Displayed in table 6, a lower average score from this tally indicated a higher ranking of importance, whereas a higher average score signaled a lower estimate of importance in the minds of the chaplains surveyed.

In the wake of question 24, interviewees were asked in question 26 to rank chaplains' functions again, not according to importance, but according to the time spent to accomplish each function. The question was asked of those participating in the interview in the same manner as described above for question 24. Table 6 provides a comparative overview for observing how the chaplains collectively responded to these two questions. 


\section{2}

TABLE 6

RANKING OF CHAPLAINS' FUNCTIONS BY IMPORTANCE AND TIME SPENT: AIM CHAPLAINS' RESPONSE

\begin{tabular}{||l|c|c|c|c||}
\hline $\begin{array}{l}\text { Rank the functions } \\
\text { performed by AIM } \\
\text { chaplains (below) } \\
\text { in order of their } \\
\text { importance and } \\
\text { time spent: }\end{array}$ & \multicolumn{2}{|c|}{$\begin{array}{c}\text { Chaplain Response } \\
\text { to Question 24: }\end{array}$} & \multicolumn{2}{|c|}{$\begin{array}{c}\text { Chaplain Response } \\
\text { to Question 26: }\end{array}$} \\
\cline { 2 - 5 } & Ranking & $\begin{array}{c}\text { Average } \\
\text { Score }\end{array}$ & Ranking & $\begin{array}{l}\text { Average } \\
\text { Score }\end{array}$ \\
\hline Intercession & Tst & 2.33 & 6 th & 4.70 \\
\hline Referral & $2 \mathrm{nd}$ & 2.38 & $3 \mathrm{rd}$ & 3.41 \\
\hline Follow-Up & $3 \mathrm{rd}$ & 3.17 & $4 \mathrm{th}$ & 3.58 \\
\hline Counseling & $4 \mathrm{th}$ & 3.58 & 1st & 2.12 \\
\hline Meetings & $5 \mathrm{th}$ & 4.71 & $5 \mathrm{th}$ & 4.66 \\
\hline Administration & $6 \mathrm{th}$ & 4.83 & $2 \mathrm{nd}$ & 2.50 \\
\hline
\end{tabular}

Table 6 overview. Table 6 reveals three interesting findings with differences of three or more rankings in the comparison of chaplains' replies to questions 24 and 26 . First, whereas surveyed chaplains ranked the function of intercession as the most important part of their role at AIM, a completely opposite finding was revealed with the reporting of their perceived time spent in interceding for callers, which ranked last. When comparing the average scores from these two questions, there was a large 2.37. point difference between the importance of and time spent with intercession by AIM chaplains. 
A second finding with almost as great a degree of polarization was discovered in this comparison of chaplains' administrative tasks, with a 2.33 point spread between the two averaged scores. Chaplains indicated their administrative duties were at the very bottom of their Iist in terms of importance, yet this function occupied the second largest amount of their time.

A final find worth mentioning in the comparison of answers to questions 24 and 26 was noted in the chaplains' perceptions about their counseling role. As a group the chaplains considered counseling of lower importance and ranked it fourth in significance. However, these same chaplains believed they spent more time in counseling than any other function by voting time spent with counseling the number one employer of their weekly hours when working at Adventist Information Ministry.

Analysis of findings. With an attempt to understand why the chaplain interviewees ranked the importance of their six key functions as they did, the dissertation now advances to the author's analysis of these related findings. We start with the function rated least important, and proceed through each of the responsibilities for Adventist Information Ministry chaplains in the reverse order of their ranked importance displayed in table 6. 


\section{Administration}

\section{A constant juggling with six important}

responsibilities. Recognizably, all six of the functions performed by AIM chaplains could be considered significant with each function having its place of importance. Many of the chaplain interviewees indicated it was difficult to separate one task from being more important than another. As with any job, the chaplains recalled that it was never easy and not always possible to give the time they felt was needed to perform each responsibility properly. "There was a tension with what had to be done" said a chaplain, "but I did the best I could within the constraints of what I could do." "I tried to do as much as possible at the same time," said another, "but there was a constant juggling. I would come in to do administrative work, but other things came up and needed to be done." ${ }^{2}$

\section{Question 30: Improving the AIM chaplain's role of}

administration. When the chaplains responding to this question voiced their suggestions, eight of them had something to contribute toward how the administrative area of their work might be improved. Their overall goal was best expressed as "freeing up chaplains to be more involved on the phone with callers and less involved with

\footnotetext{
${ }^{1}$ Chaplain \#26, telephone interview by author, April 25, 1994.

${ }^{2}$ Chaplain \#43, telephone interview by author, April 28, 1994.
} 
administration." ${ }^{1}$ One way of accomplishing this was revealed in a chaplain's recommendation to employ "a fulltime secretary for chaplains' paperwork." ${ }^{2}$ Another approach to the struggle of administrative overload came from this chaplain who suggested "having all the information chaplains need on computer. " 3

Question 27: Time-management adjustments. Knowing first-hand the wrestling match chaplains experienced with the challenge of managing their time while working as parttime employees at AIM and full-time graduate students at the Seminary, the author asked in question 27: "What timemanagement adjustments did you make in order to deal with these multiple tasks?"

A couple of chaplains simply replied "none." A few others identified a traditional solution for solving similar problems by "devoting more time to the job, from 10 hours to 15 hours per week." ${ }^{4}$ However, the results of that approach were not always satisfying. As one chaplain commented, "I tried to work more hours," but found that method "frustrating . . . trying to keep up with data entry." ${ }^{5}$

${ }^{1}$ Chaplain \#19, telephone interview by author, May 4, 1994.

${ }^{2}$ Chaplain \#28, telephone interview by author, April 29, 1994.

${ }^{3}$ Chaplain \#26, telephone interview by author, April 25, 1994.

${ }^{4}$ Chaplain \#35, telephone interview by author, April 25, 1994.

${ }^{5}$ Chaplain \#28, telephone interview by author, April 29, 1994. 
A few chaplains described more creative adjustments made to deal with the multiple tasks assigned to them. One such interviewee mentioned they "contributed to a meeting where designated roles in harmony with the chaplain's spiritual gifts were enacted which helped expedite the chaplain's work greatly." That chaplain felt the resulting bigger block of time given to pursue one AIM function in particular helped them individually, and the chaplains as a team, to be more productive. ${ }^{1}$ A similar testimony came from a chaplain who was part of another squad which had also looked favorably upon a gifts-based concept. He noted, "I had a gift in administration regarding the computer which helped others save time." ${ }^{2}$

\section{Meetings}

Question 21 of the interview instrument asked, "What were the strengths and weaknesses of the chaplains" meetings?" Twenty-four of the twenty-six chaplains who were surveyed responded to this question. Three of the twentyfour indicated they either did "not recall any chaplains' meetings" ${ }^{3}$ or they could not "remember our meeting together." ${ }^{4}$ Another two chaplains said "there were no

\footnotetext{
${ }^{1}$ Chaplain \#41, telephone interview by author, April 29, 1994.

${ }^{2}$ Chaplain \#40, telephone interview by author, April 27, 1994.

${ }^{3}$ Chaplain \#33, telephone interview by author, May 2, 1994.

${ }^{4}$ Chaplain \#48, telephone interview by author, April 27, 1994.
} 
meetings then," "while one chaplain "rarely sat in on them," because "my schedule presented some conflicts and they did not seek to accommodate it." ${ }^{2}$

\section{Question 21: Weaknesses of chaplains' meetings.}

As can occur with meetings of any type, problems associated with length and frequency were mentioned by four of the eighteen chaplains who offered a reply to this question. "Not starting and ending on time" ${ }^{3}$ was cited, and that "the format was too long for its time constraints." ${ }^{4}$ It was felt that chaplains meetings' "could be less frequent." Instead of weekly meetings it was believed that "two a month" would be adequate. ${ }^{5}$

Another group of frustrations revolved around the way in which business items were handled, as with "repeated information, nuts and bolts procedures, etc." ${ }^{6}$ To deal with this problem one chaplain suggested "more items could be put on voice mail," (whereas another chaplain felt this had recently been done and thus viewed "cutting back on

\footnotetext{
${ }^{1}$ Chaplain \#19, telephone interview by author, May 4, 1994.

${ }^{2}$ Chaplain \#14, telephone interview by author, April 25, 1994.

${ }^{3}$ Chaplain \#46, telephone interview by author, April 27, 1994.

${ }^{4}$ Chaplain \#25, telephone interview by author, May 3, 1994 .

${ }^{5}$ Chaplain \#11, telephone interview by author, May 1, 1994.

${ }^{6}$ Chaplain \#26, telephone interview by author, April 25, 1994.

${ }^{7}$ Chaplain \#11, telephone interview by author, May 1, 1994.
} 
announcements by putting them on voice mail" ${ }^{1}$ as a strength rather than a weakness of the chaplains' meetings). "Input on business items that fell by the wayside" with a lack of follow-up by supervisory staff was also mentioned, though the chaplain voicing this critique understood this may have been "possibly due to lack of funds." 2 For another, the chaplains' meetings "lacked a sense of direction," and became bogged down with business-item details. ${ }^{3}$ One chaplain believed this was the result of the "coordinator's administrative style." ${ }^{4}$

Nearly one half of the chaplains responding to the 21st interview question said in effect that "the weakest component" of their chaplains' meetings "was the professional development" segment. 5 "Its pastoral/ devotional nature took from limited time needed to discuss and further develop chaplains' tasks." ${ }^{6}$ The same concern was expressed by another chaplain who said the "coordinator presented material not essential for chaplain's work dealing with Christianity in general," thus the "presentation style

${ }^{1}$ Chaplain \#46, telephone interview by author, April 27, 1994.

${ }^{2}$ Chaplain \#41, telephone interview by author, April 29, 1994.

${ }^{3}$ Chaplain \#28, telephone interview by author, April 29, 1994.

${ }^{4}$ Chaplain \#43, telephone interview by author, April 28, 1994.

${ }^{5}$ Chaplain \#40, telephone interview by author, April 29, 1994.

${ }^{6}$ Chaplain \#25, telephone interview by author, May 3, 1994. 
was boring." ${ }^{1}$ It was estimated by another chaplain that "professional development was $40 \%$ helpful and tailored to chaplains and 60\% Christian devotional. "2 Consequently, while the professional development time in the chaplains' meetings was viewed by one individual as "very spiritual," it was also perceived by this same person to be "not equipping me as a chaplain." ${ }^{3}$ Because "professional development was more pastoral than oriented toward chaplain's duties," 4 or more devotional then helpful in the minds of $45.8 \%$ of the surveyed chaplains responding to this question, it could be said that "professional development . . didn't apply to chaplains" ${ }^{5}$ very well. The only suggestion expressed by the interviewed chaplains for improving the professional development segment of the weekly chaplains' meetings was to schedule it half as often. ${ }^{6}$

\section{Question 21: Strengths of chaplains' meetings.}

Eighteen of the chaplains identified strengths associated with their chaplains' meetings at Adventist Information Ministry. From a general point of view, one individual

\footnotetext{
${ }^{1}$ Chaplain \#27, telephone interview by author, April 26, 1994.

${ }^{2}$ Chaplain \#28, telephone interview by author, April 29, 1994.

${ }^{3}$ Chaplain \#29, telephone interview by author, May 3, 1994.

${ }^{4}$ Chaplain \#44, telephone interview by author, May 1, 1994.

${ }^{5}$ Chaplain \#41, telephone interview by author, April 29, 1994.

${ }^{6}$ Chaplain \#11, telephone interview by author, May 1, 1994.
} 
believed that the meetings were helpful in that they "provided for coordination and communication." ${ }^{1}$ of the remaining chaplains who shared their views on the strengths of the chaplains' meetings, there was overwhelming agreement upon what they believed was the vital strength. Here are some of the reasons why $70.8 \%$ of the chaplains answering question 21 "valued the discussions" ${ }^{2}$ they engaged in during the meetings "with everyone contributing" 3 more than anything else: "Communicating about what is going on with the chaplains department" 4 and "talking about chaplains' work as co-workers created a bond" that was synergetic for the chaplains who met together weekly. This was especially true when a certain portion of the meeting time was reserved for an "opportunity to talk about individuals who were difficult to deal with." ${ }^{6}$ These "discussions," with their "dynamics of openness and willingness to share," " "helped morale and eased burdens" 8 among the chaplains. The discussions were viewed as appreciably assisting the

\footnotetext{
${ }^{1}$ Chaplain \#15, telephone interview by author, April 25, 1994.

${ }^{2}$ Chaplain \#18, telephone interview by author, May 3, 1994.

${ }^{3}$ Chaplain \#31, telephone interview by author, May 1, 1994.

${ }^{4}$ Chaplain \#35, telephone interview by author, April 29, 1994.

${ }^{5}$ Chaplain \#32, telephone interview by author, May 2, 1994.

${ }^{6}$ Chaplain \#23, telephone interview by author, April 26, 1994.

${ }^{7}$ Chaplain \#12, telephone interview by author, May 3, 1994.

${ }^{8}$ Chaplain \#11, telephone interview by author, May 1, 1994.
} 
chaplains in their ability to "see people's needs better," and thus they were greatly "valued."1

Two strengths in particular were commented on by the interviewed chaplains. Exactly one fourth of the twentyfour total chaplains who answered the $21^{\text {st }}$ question looked upon the prayer component of their meetings as "very helpful."2 "Receiving spiritual support in prayer for each other" ${ }^{3}$ was considered a strength "when applied to chaplains."4 As a result, at least one chaplain recommended that this spiritual dimension of the chaplains' meetings be even further strengthened. ${ }^{5}$

As for the other strength associated with the chaplains' meetings, it was revealed that "discussions" among the chaplains during their meetings provided important support and resources which helped in part to make up for what was believed to be lacking elsewhere for the chaplains' development. Six separate chaplains cited in particular how "sharing situations with other callers" was the single most helpful element of their discussions. ${ }^{6}$ Their "sharing and

\footnotetext{
${ }^{2}$ Chaplain \#18, telephone interview by author, May 3, 1994.

${ }^{2}$ Chaplain \#26, telephone interview by author, April 25, 1994.

${ }^{3}$ Chaplain \#25, telephone interview by author, May 3, 1994.

${ }^{4}$ Chaplain \#41, telephone interview by author, April 29, 1994.

${ }^{5}$ Chaplain \#29, telephone interview by author, May 3, 1994.

${ }^{6}$ Chaplain \#26, telephone interview by author, April 25, 1994 .
} 
debriefing in what chaplains come up against" ${ }^{1}$ further led to "incorporating verbatims to help sharpen these skills," which was considered a strengthening aspect of the chaplains' meetings by more than one interviewee.

\section{Counseling}

Question 20 asked: "Is it within the scope of the AIM chaplain's ministry to do counseling?" of the interviewed chaplains, $96.1 \%$ answered this question, with all twenty-five who responded answering yes in one form or another. However, qualifiers abounded with a variety of opinions voiced by the chaplains about this aspect of their role at Adventist Information Ministry.

\section{How the phrase "counselor" and its alternatives were}

viewed. For starters, the very term "counselor" brought a degree of discomfort to the chaplains as a whole. One chaplain said, "Legally we were not to use the word 'counselor.' Our main responsibility was to refer. In that we did help figure out problems callers faced," this chaplain wondered, "is there a better term than counselor?" ${ }^{3}$ Another chaplain suggested that "guidance" would be "a better term than counseling, especially for chaplains who are not ordained." This chaplain went on to say that "even

\footnotetext{
${ }^{1}$ Chaplain \#29, telephone interview by author, May 3, 1994.

${ }^{2}$ Chaplain \#28, telephone interview by author, April 29, 1994.

${ }^{3}$ Chaplain \#40, telephone interview by author, April 29, 1994.
} 
pastoral counseling can be associated with certification and Iicensing, so it is not the best term either." ${ }^{1}$ still

another chaplain who was in favor of using the term

"guidance" noted that the phrase "spiritual guidance differs from counseling, which is a formal process involving a longterm relationship with a counselee, whereas spiritual

guidance gives short answers to any questions that may arise. " ${ }^{2}$

Not every chaplain agreed with these concerns about the pastoral counseling term. "Many callers want it" argued one chaplain, who went on to say that "pastoral counseling . . not professional counseling. . . is short-term.

Beyond one session it should be referred." ${ }^{3}$ said another, while "callers need to know that a chaplain is at AIM for referrals," there is a place for "pastoral counseling." This chaplain then added the qualifier, but "only for the senior chaplain." 4

The term most frequently used by the interviewed chaplains for the function of counseling at AIM was that of "spiritual counseling," with a range of definitions, Iimitations, and liabilities accompanying it, as has already been suggested. "Spiritual counseling is helping people

\footnotetext{
${ }^{1}$ Chaplain \#33, telephone interview by author, May 2, 1994.

${ }^{2}$ Chaplain \#18, telephone interview by author, May 3, 1994.

${ }^{3}$ Chaplain \#25, telephone interview by author, May 3, 1994.

${ }^{4}$ Chaplain \#31, telephone interview by author, May 1, 1994.
} 
with issues from a Biblical standpoint. But it depends on how much time you spend with it." ${ }^{1}$ "We were definitely told we were not technically counseling but rather doing spiritual counseling. A disclaimer statement said we were not trained or licensed." ${ }^{2}$ For another chaplain, the phrase "spiritual counseling" was associated with "Bible information, spiritual warfare, and staying out of marriage counseling." This was because "counseling is a broad word - . We need to realize our limitations, as we can't do what we are not trained to do." ${ }^{3}$ Raising similar concerns, a final chaplain signaled that "there is room for spiritual or Christian counseling with listening the focus, but it should not be the main thing at AIM. We do not have the professional training for it." ${ }^{4}$

Question 20: Executive steering committee views. previously identified the 20 th question of the interview asked, "Is it within the scope of the AIM chaplain's ministry to do counseling?" Here is how the five executive steering committee members who replied to question 20 answered (followed by the AIM staff), with their responses revealed in back-to-back quoting set forth in the order of

\footnotetext{
${ }^{1}$ Chaplain \#11, telephone interview by author, May 1, 1994.

${ }^{2}$ Chaplain \#12, telephone interview by author, May 3, 1994.

${ }^{3}$ Chaplain \#23, telephone interview by author, April 26, 1994.

${ }^{4}$ Chaplain \#29, telephone interview by author, May 3, 1994.
} 
the date and time each member of the respective group was interviewed.

No, not in a formal sense. I hesitate to use the term counseling. Spiritual advising, yes. Pastors are not licensed counselors, and the term counseling is associated with licensor. Over the phone there's no body language and a chaplain is not able to intervene. We can talk about the Bible. I even dislike using the term pastoral counseling. What we do is a form of pastoral nurture. ${ }^{1}$

"Counseling is a delicate word, and in this day and time you can be sued for this. Chaplains do consult in the sense of offering friendship and prayer to someone on the line." 2 "Counseling is not the primary purpose or responsibility of the AIM chaplain, but it ends up happening. We can't not help that person calling in. There's no way out of it." ${ }^{3}$ "Not professional counseling. . . But AIM chaplains do talk with folks. They should direct the individual in need to someone who can help." "Chaplains don't do counseling, they refer them to professional counseling. Chaplains do give some advice." ${ }^{5}$

Question 20: Staff viewpoint. "The AIM chaplain's counseling is legitimate if qualified. With each caller at a different point in life, AIM's purpose here is to answer

\footnotetext{
${ }^{1}$ Committee \#55, telephone interview by author, April 28, 1994.

${ }^{2}$ Committee \#59, telephone interview by author, April 28, 1994.

${ }^{3}$ Committee \#56, telephone interview by author, May 2, 1994.

${ }^{4}$ Committee \#57, telephone interview by author, May 3, 1994.

${ }^{5}$ Committee \#58, telephone interview by author, May 6, 1994 .
} 
each of their questions to the extent possible in bridging counseling." "While many callers initially contact AIM with a counseling need, chaplains do not work as a fullfledged counselor with an ongoing, lengthy working through of a problem." "AIM chaplains counsel up to a point. The chaplains have some program they go through in Seminary to give some training for this. Ideally they should refer these callers to a local professional, which they do well." 3

Counseling is a term that. . . is subject to liability. So we've disassociated ourselves from counseling. Pastoral counseling or spiritual counseling is what we do. AIM does have a copyright to do counseling. As far as the federal government is concerned, yes, we do counseling, but not as licensed counselors. At least one master's student has done practicum work in counseling at AIM. We have also worked with Ph.D.'s in counseling to review our chaplains' material used toward this. ${ }^{4}$

\section{Referral and Follow-Up}

AIM chaplains ranked the function of referral a very close second in importance to intercession, with a tiny 0.05 difference between the average scores associated with these two functions. In response to the $25^{\text {th }}$ question which asked, "Why did you rank these functions for AIM chaplains in the order that you did?," more than a few of the

\footnotetext{
${ }^{1}$ Staff \#85, telephone interview by author, April 25, 1994.

2Staff \#86, telephone interview by author, April 28, 1994.

${ }^{3}$ Staff \#84, telephone interview by author, April 29, 1994.

${ }^{4}$ Staff \#88, telephone interview by author, May 2-4, 1994.
} 
chaplains gave similar. replies such as this one, "The mission of AIM is to be a referral service."1

Linking the functions of referral and follow-up together was an important affiliation made by another chaplain who commented, "Going back to AIM as a vital link, referral and follow-up are at the top of the list." ${ }^{2}$ It appears that the interviewed chaplains as a whole made a similar association by ranking the importance of their follow-up task a close third, with the function of follow-up trailing referral by a small difference of only 0.79 points when comparing the two averaged scores together.

\section{Question 31: Significant contributions of the AIM} chaplain. The $31^{\text {st }}$ question of the interview asked, "What has been the chaplain's most significant contribution to AIM?" This particular question resulted in a poor response rate in the wake of question 28 which was similar and extracted most of the interviewees' thoughts regarding their personal contributions to AIM. Though no committee members, no pastors, two staff, and only six chaplains responded, it would be appropriate to mention these few comments here.

Five of the six chaplains made an association with "pastors" in their answer to the $31^{\text {st }}$ question, indicating their impression that the chaplain's role at AIM centered on

\footnotetext{
${ }^{1}$ Chaplain \#15, telephone interview by author, April 25, 1994. ${ }^{2}$ Chaplain \#28, telephone interview by author, April 29, 1994.
} 
helping facilitate pastors in their soul-winning work.

Along this line one chaplain stated, "To provide a rapid way of getting referral information to pastors" was the chaplains' greatest contribution to AIM as a group.'

Of the six chaplain replies to this question, three of the references revolved around the chaplains' work of referrals, while the remaining three comments were directed to the chaplain's follow-up function. Regarding the latter role, "a contact point with local pastors or elders to find out how things have gone" ${ }^{2}$ was how one chaplain put it. Said one other, "keeping track of follow-up" was the AIM chaplains' most significant contribution. "Though chaplains are not watchdogs, pastors forget." ${ }^{3}$

\section{Question 30: Improvements suggested. Only three}

chaplains had specific counsel regarding referral and follow-up functions for the AIM chaplain. One of them simply desired for chaplains to "become more efficient in referral and follow-up." ${ }^{4}$ Another wished for the chaplains to be "spending more time with follow-up, as it's difficult to stay on top of everything as a pastor." ${ }^{5}$ The last of

\footnotetext{
${ }^{1}$ Chaplain \#26, telephone interview by author, April 25, 1994.

${ }^{2}$ Chaplain \#14, telephone interview by author, April 25, 1994.

${ }^{3}$ Chaplain \#46, telephone interview by author, April 27, 1994 .

${ }^{4}$ Chaplain \#35, telephone interview by author, April 25, 1994.

${ }^{5}$ Chaplain \#23, telephone interview by author, April 26, 1994.
} 
these three chaplains hoped for "not having as big a church" for future AIM chaplains. He asked, "Is there some way of reducing the 300 members in a chaplain's follow-up territory, as in getting another person to share the load?"1 From the perspective of the one pastor who replied to question 30, he felt that "sometimes chaplains are unable to accurately assess the situation with an interest who supposedly requests a Bible study. But when a pastor contacts them. . they do not want one." ${ }^{2}$ This gospel minister thus wondered if there was some way to improve upon the accuracy of the Adventist Information Ministry chaplain's referrals.

\section{Intercession}

Fifteen of the surveyed chaplains responded to question 25 which asked: "Why did you rank these functions for AIM chaplains in the order that you did?" Reasons for citing intercession as the most important function of the AIM chaplain varied from "this is where the power is" ${ }^{3}$ and "nothing happens without God," to "it's [intercession or prayer] the greatest tool any Christian has to work with." 5

\footnotetext{
${ }^{1}$ Chaplain \#29, telephone interview by author, May 3, 1994.

${ }^{2}$ Pastor \#77, telephone interview by author, May 3, 1994.

${ }^{3}$ Chaplain \#23, telephone interview by author, April 25, 1994.

${ }^{4}$ Chaplain \#41, telephone interview by author, April 29, 1994.

${ }^{5}$ Chaplain \#26, telephone interview by author, April 25, 1994.
} 
Question 22: Staff and committee response. The $22^{\text {nd }}$ question of the telephone interview asked, "Describe your philosophy for how prayer requests called in to AIM's 800number should be handled." In reply, one staff member offered this historical perspective:

The concepts for handling prayer requests at AIM originally started with the media center gathering around a name and praying. AIM developed the interest card which included prayer requests. A former senior chaplain distributed cards to workers (with names and brief requests) to pray for - . . A shift leader invited workers after the reading of a name to periodically pray for that person during the shift. Cards are returned to the shift leader who passes them on to the follow-up coordinator who has conducted diagnostic studies and put together prayer training modules based on these cards.

Not everyone on the AIM staff fully agreed with the manner in which prayer requests were being handled. Said one staff member, "Initially the operator should volunteer prayer on the spot. If the caller declines, then forward their prayer requests to working staff who forward them to worships for prayer." ${ }^{2}$ Another staff member essentially stated the same thing in saying, "Phone operators need to offer prayer on the spot and then ask if the caller would like to be added to the prayer list. We should continue in prayer on behalf of these requests until an answer is given." ${ }^{3}$ A final staff person concluded, "Practically

\footnotetext{
${ }^{1}$ Staff \#88, telephone interview by author, May 2-4, 1994.

'staff \#86, telephone interview by author, April 28, 1994.

${ }^{3}$ Staff \#84, telephone interview by author, April 29, 1994.
} 
speaking, our procedures seem to be working. Philosophically, people expect to be prayed over, and we don't always do this."1

One executive steering committee member concurred with the manner in which prayer requests were being handled, believing AIM should "have some type of prayer group with prayer requests distributed to different areas of the work place or different prayer groups. Record should be kept of the follow-up or answers to prayer." ${ }^{2}$ Another committee member was comfortable when operators would either "pray [immediately] over the phone with a person or [at a later time] during prayer sessions at work." ${ }^{3}$ A third person on the AIM committee was concerned when "some callers want an immediate response. To say we will pray with you at a later date is not as meaningful." ${ }^{4}$ Still another committee member believed AIM employees needed to be sensitive to the best timing for when to pray with a caller and said, "If an AIM worker senses prayer is appropriate, then pray on the spot." ${ }^{5}$ A final member of the committee group felt it was imperative to pray on the spot, believing that "the Holy Spirit is working. So they do call, and it may be one

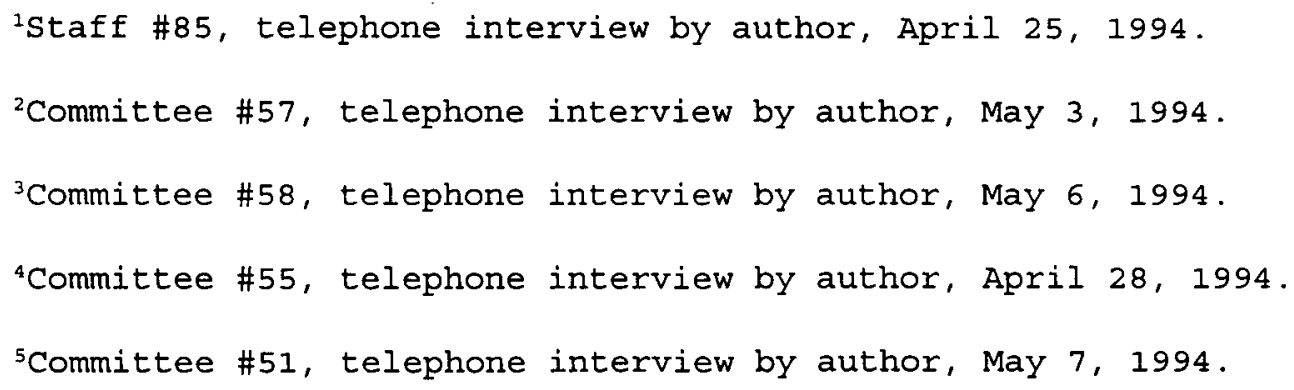


chance in a lifetime to lead that caller in the right direction. Thus prayer on the spot is a necessity."1

Question 22: Chaplains' reply. The chaplains as a whole spoke out strongly in response to this open-ended question regarding the matter of prayer ministry at AIM. Again, the 22nd question asked, "Describe your philosophy for how prayer requests called in to AIM's 800 number should be handled." While one-eighth of the group stated in some definitive fashion that prayer requests were being handled satisfactorily or appropriately, the remaining seven-eighths of the group voiced quite a number of concerns.

Close to one-half of the twenty-four chaplains responding to question 22 spoke of a desire to see the handling of prayer requests at AIM improved in some way, with one-third of the chaplain group speaking about their concern in what the author perceived to be an impassioned manner. Dates of service associated with these AIM chaplains who spoke in a passionate way about improving intercession were examined to see if a particular time period had any bearing on the matter. It was noted that the years 1986 through 1994 were included, with the bulk of those speaking fervently having worked at AIM during 1990-1994.

${ }^{1}$ Committee \#59, telephone interview by author, April 28, 1994. 
Probably the strongest appeal for bettering the role of intercession at AIM came from a chaplain who worked for one year between the 1986 and 1990 period. He said the manner in which prayer requests were handled was his "highest area of discomfort" while working as a chaplain at Adventist Information Ministry. He elaborated, "We took these requests and prayed as a passive thing to fulfill an obligation rather than engage in a spiritual ministry." He felt that "operators should be encouraged to engage in onthe-spot prayer with callers. For prayer requests not yet prayed for, set a specific time to invite people to come in and pray as a priority ministry rather than an adjunct." 1

\section{Chaplains' ideas for improving AIM's prayer}

ministry. As may be discerned from the chaplain's comments above, calls for the improvement of the prayer ministry at AIM seemed to revolve around three key issues for the interviewed chaplains. Simply stated, these were: (1) timing--when should prayer occur? (2) manner--how should intercession occur? and (3) personnel--who should pray for these requests at Adventist Information Ministry?

\section{Timing: When should intercession occur at AIM?}

Praying in a timely manner for a person who had called the AIM 800-number was important to quite a few of the chaplains surveyed. Said one interviewee, "For requests with a time 
factor, make sure they are prayed for as quickly as possible." Almost one-third of the chaplains specified that phone operators and chaplains at AIM should "pray with people on the phone at that time rather than write out prayer requests for later prayer." ${ }^{2}$ One example of the reasons cited for this included a perceived spiritual benefit resulting from praying "with the caller when the call first comes in." ${ }^{3}$

Said another chaplain, "When appropriate pray then with the person on the phone," who added a note of caution about immediately jumping into prayer with every caller because, based on his own experience, "a personal invitation for prayer requests did not always go well." " Possibly this is why one other of the twenty-four chaplains responding to the $22^{\text {nd }}$ question said, "You don't necessarily have to pray for the caller on the spot. $1{ }^{5}$

Given the cautionary notes from these AIM chaplains about the importance of timing when involved in intercession with AIM callers, the question might be asked, What parameters should be linked with intercession at AIM to make the improvements desired?

\footnotetext{
${ }^{1}$ Chaplain \#46, telephone interview by author, April 27, 1994.

${ }^{2}$ Chaplain \#19, telephone interview by author, May 4, 1994.

${ }^{3}$ Chaplain \#23, telephone interview by author, April 26, 1994.

${ }^{4}$ Chaplain \#46, telephone interview by author, April 25, 1994.

${ }^{5}$ Chaplain \#34, telephone interview by author, April 29, 1994.
} 
Manner: How should AIM prayer requests be handled?

If prayer requests are not handled "on the spot," how should they be responded to when prayer is offered at a later time or date? One answer to that question came from a chaplain proposing a little different spin on the question of when intercession should be pursued. "To pray for the caller on time" means "up to the event they have requested prayer for." 1 In this chaplain's mind, that meant not necessarily praying for a person on the spot but making sure meaningful prayer was offered anytime prior to the passing of the event or circumstances that led the caller to phone AIM for prayer. This same chaplain's philosophy for handling prayer requests included "dividing up into small groups and actually praying for them, not reading requests out loud." ${ }^{2}$ Another chaplain proclaimed a similar concern with his suggestion to take prayer requests "a lot more seriously." His feeling was that prayer for caller requests at AIM "became a formality when handed out to operators just to read." His proposition was "to share with workers the principles of intercession, how to pray, and use these requests for teaching this." ${ }^{3}$ Having operators who prayed "not just as an accessory with a routine reading" was viewed

${ }^{1}$ Chaplain \#40, telephone interview by author, April 29, 1994.

${ }^{2}$ Ibid,

${ }^{3}$ Chaplain \#41, telephone interview by author, April 29, 1994. 
as an opportunity for "a life-changing medium" for all employees who take phone calls at AIM."1

Personnel: Who should be interceding at AIM? More then half of the surveyed chaplains looked to the front-Iine phone operators who first receive the requests for prayer as the AIM personnel who should initially pray with the caller. Said one interviewee, "To pray for the caller when the call first comes in. . should also help the operator. If they don't pray, then pass it on to a chaplain to pray with them. ${ }^{2}$

For prayer requests not immediately managed by the operator, another chaplain shared this experience: "Not being satisfied with the way prayer requests were being handled, I distributed these for workers to individually pray over during worship time. . . because it seemed like AIM wasn't giving intercession the thought they should." ${ }^{3}$ Another chaplain stated a similar strategy by saying, "Passing out requests to be prayed for during a lull time with a busy call-in was generally well received when operators were asked if they would pray for a person." 4

${ }^{1}$ Chaplain \#44, telephone interview by author, May 1, 1994.

${ }^{2}$ Chaplain \#23, telephone interview by author, April 26, 1994.

${ }^{3}$ Chaplain \#28, telephone interview by author, April 29, 1994.

${ }^{4}$ Chaplain \#46, telephone interview by author, April 27, 1994. 
Suggestions for a group approach to managing prayer requests were voiced by a third of the chaplains interviewed. For at least one chaplain, a small group in prayer was preferred to individuals responding to the many prayer requests voiced across AIM phone lines. He testified, "At first I would grab a card and offer a quick prayer. Toward the end of my tenure at AIM I spent more time with prayer cards in small groups praying for callers individually." ${ }^{1}$ However, a few of the interviewed chaplains voiced concerns about this method, because for them it "became a formality when prayer requests were handed out to operators just to read." ${ }^{2}$ one chaplain thus suggested that the handling of prayer requests at AIM "could be developed more, as with a prayer ministry team." ${ }^{3}$ That chaplain believed it would be helpful if such a prayer ministry team would "become an integrated part of the chaplains' meeting." ${ }^{4}$ Other chaplains saw themselves as the personnel, in conjunction with their meeting as the place, where "more emphasis on prayer cards" ${ }^{5}$ should occur without becoming routine.

\footnotetext{
${ }^{1}$ Chaplain \#18, telephone interview by author, May 3, 1994.

${ }^{2}$ Chaplain \#41, telephone interview by author, April 29, 1994.

${ }^{3}$ Chaplain \#27, telephone interview by author, April 26, 1994.

${ }^{4}$ Ibid.

${ }^{5}$ Chaplain \#18, telephone interview by author, May 3, 1994.
} 
Specialization in responding to prayer requests from either an individual or a group took a spiritual gifts-based track for the following suggestions, as with this chaplain who envisioned "a specialized ministry at AIM which could pray for these requests in harmony with their capabilities." 1 Said another, "AIM should have a daily prayer ministry with certain called people praying for prayer requests in a more meaningful manner." For this same chaplain, dedicating "an hour of intercession" was viewed as one way to make this component of AIM's ministry more meaningful. ${ }^{2}$ A final chaplain believed AIM "could have a person overseeing prayer ministry who has the spiritual gift of intercession that could spur it on." ${ }^{3}$

Questions 24 and 25: Committee, Founders, and staff Ranking of the AIM Chaplains' Fundamental Responsibilities

Question 24: Ranking the chaplains' fundamental functions. As observed on the first page of the interview instrument under the section titled "Questions," three other groups of interviewees were asked question 24: "Rank the following functions performed by AIM chaplains in order of their importance." From the AIM committee/founders' category, five of the ten dissertation interviewees replied

\footnotetext{
${ }^{1}$ Chaplain \#33, telephone interview by author, May 2, 1994.

${ }^{2}$ Chaplain \#25, telephone interview by author, May 3, 1994.

${ }^{3}$ Chaplain \#44, telephone interview by author, May 1, 1994.
} 
to this question. Admittedly, a 50 percent sampling rate could be understood as not particularly representative of the entire group's viewpoint. However, these five individuals collectively attended forty-six AIM executive steering committee meetings (see Appendix $\mathrm{H}$ ), which illustrates how this group of five primarily included persons who would be considered influential AIM leaders. Thus it was felt by the author that their response to question 24 should be included, along with all four of the AIM staff interviewees who answered this 24 th question. Rankings given to the importance of AIM chaplains' functions by these two groups can be compared in table 7 .

\section{TABLE 7}

RANKING OF CHAPLAINS' FUNCTIONS BY IMPORTANCE: AIM COMMITTEE/FOUNDERS AND AIM STAFF RESPONSE

\begin{tabular}{|c|c|c|c|c|}
\hline \multirow{2}{*}{$\begin{array}{l}\text { Rank the functions } \\
\text { performed by AIM } \\
\text { chaplains (below) } \\
\text { in order of their } \\
\text { importance: }\end{array}$} & \multicolumn{2}{|c|}{$\begin{array}{c}\text { Committee/Founders } \\
\text { Response to } Q .24: \\
\text { IMPORTANCE }\end{array}$} & \multicolumn{2}{|c|}{$\begin{array}{l}\text { Staff Response } \\
\text { To Question } 24: \\
\text { IMPORTANCE }\end{array}$} \\
\hline & Ranking & Average & Ranking & Average \\
\hline Referral & $1 s t$ & 1.80 & 1 st & 1.50 \\
\hline Counseling & $2 n d$ & 2.00 & 5 th & 4.75 \\
\hline Intercession & $3 r d$ & 3.00 & $3 r d$ & 3.50 \\
\hline Follow-Up & 4 th & 4.00 & 2 nd & 2.75 \\
\hline Meetings & 5 th & 4.20 & 6 th & 5.50 \\
\hline Administrative & $6 t h$ & 5.80 & 4 th & 4.25 \\
\hline
\end{tabular}




\section{Question 25: Reasons for rankings revealed in}

table 7. The $25^{\text {th }}$ question of the phone survey asked, "Why did you rank these functions for AIM chaplains in the order that you did?" One person in the committee/founder category saw a progressive order to the chaplains' functions beginning with counseling, then intercession, followed by referral with follow-up being next.' Another individual from this group likewise ranked counseling the most important function for the AIM chaplain, with a slightly different progression that followed in that of referral second and intercession third, all of which were viewed "pretty close together." ${ }^{2}$ A third committee member "listed them chronologically in terms of the order functions would seem to occur." ${ }^{3}$ For that individual, meetings received the number one ranking, then counseling followed by referral, intercession, administration, and finally follow-up.

Another committee member likewise ranked counseling as the second most important function for the AIM chaplain following referral. He proceeded to give the reason why by stating: "Referral is most important. AIM is not a counseling center." 4 One other person with the committee group began with referral in his ranking of the importance

\footnotetext{
${ }^{1}$ Committee \#59, telephone interview by author, April 28, 1994.

${ }^{2}$ Committee \#58, telephone interview by author, May 6,1994 .

${ }^{3}$ Committee \#57, telephone interview by author, April 28, 1994.

${ }^{4}$ Committee \#56, telephone interview by author, May 2, 1994.
} 
of the AIM chaplain's functions, followed by intercession, follow-up, counseling, meetings, and lastly administration. ${ }^{1}$

One of the two AIM staff members who responded to the $25^{\text {th }}$ question likewise rated referral as most important. This person said:

Referral is most important since we exist for follow-up and to refer as quickly as possible. Regarding administration, there needs to be documentation, especially with the turnover we have and with NADEI [North American Division Evangelism Institute] students. As for meetings, we need to compare notes especially with regular callers. ${ }^{2}$

Whereas the staff person who was just quoted listed intercession as the second most important function, the other staff member saw it differently because "phone operators should have already prayed with the caller, thus intercession is listed last. Counseling is listed fifth because we must get the interests to the field first." ${ }^{3}$

Similarities found. In general, the data in table 7 reveal that the staff at AIM and the members of the executive steering committee/founders' group who responded to question 24 were aligned quite closely in a majority of their perceptions assigned to importance for the chaplain's functions. For example, both of these groups viewed the chaplain's work of referral with uttermost importance.

\footnotetext{
${ }^{1}$ Committee \#55, telephone interview by author, April 28, 1994.

${ }^{2}$ Staff \#88, telephone interview by author, May 2-4, 1994 .

${ }^{3}$ Staff \#84, telephone interview by author, April 29, 1994.
} 
Scoring for the importance of intercession, follow-up of interests, chaplains' meetings, and administrative duties revealed reasonably similar thinking as well.

\section{Two surprising findings from table 7 . A curious} discovery was picked up in the ranking of importance given to chaplains' administrative duties by the AIM executive steering committee. For a group of executives better known as administrators, the last-place ranking applied to the importance of administration for the AIM chaplain was viewed by the author as somewhat paradoxical. While their view could certainly be regarded as a credit for displaying the belief that ministers performing administrative work do not have to make it their number one task, seeing administrators rank administration last in importance for the role of the AIM chaplain was still somewhat of a surprise.

The one ranking displayed in table 7 which stood out as being very different between the two groups was how the AIM executive steering committee and AIM staff viewed the importance of counseling for the AIM chaplain. Whereas the staff at AIM counted this function next to last in terms of importance, the AIM steering committee regarded counseling as the next to most important work done by the chaplains at AIM. There was a large point difference of 2.75 noted between the committee and staff viewpoints, which was greater than any difference observed among the chaplains' rankings for question 24 (see table 6). The author looked 
upon this finding revealed in table 7 with interest because it contrasted sharply with a view reportedly held by the AIM executive committee regarding this very responsibility performed by the AIM chaplain. Discussion of this view will surface in the next chapter where the author presents his conclusions and recommendations for the role of the AIM chaplain. 
CHAPTER FIVE

SUMMARIES, RECOMMENDATIONS, AND CONCLUSIONS

\section{Introduction}

During his late teens and early twenties the author enjoyed climbing a number of snow-capped mountains while living in the Pacific Northwest. These exhilarating adventures started with many preparatory activities prior to arrival at the base of the mountain where the journey on foot began. Climbing the mountain was an invigorating and lengthy walk uphill until arrival at the peak where you lingered a short while to enjoy the view. Then came the descent, which generally returned through the same terrain but from a different angle and at a much quicker pace.

We are ready to step down from the peak of the dissertation so to speak as chapter 5 begins. Our descent will take us back through the three major subject areas that were the focus of chapters 4, 3, and 2. Readers will view a separate summary for each of these chapters, the author's conclusions to the key topics including recommendations for the AIM chaplain's role, and a final conclusion for the dissertation. Compared to the uphill climb through the first four chapters, the downhill stride in chapter 5 will 
be more accelerated. We begin our journey into this final chapter of the dissertation straightaway with parting views of the Adventist Information Ministry chaplain.

\section{Summary of Chapter 4}

Leading up to the years that Adventist Information Ministry was taking shape, a renewed conviction about evangelism in the North American Division of the Seventh-day Adventist church was gathering momentum. The Adventist Information Service/Ministry chaplain was created in the midst of this backdrop, which included a reminder call for ministerial leadership to provide proper follow-up of evangelism interests. The "chaplain" name was chosen with a desire to communicate an impartial sense of spiritual helpfulness to media viewers dialing in their requests to the newly established toll-free help-line. Seminary students were selected to serve in this capacity because of their pastoral background and further ministerial training being pursued at Andrews University. Establishing initial objectives for the A.I.S./AIM chaplain included a three-step system of interest evaluation and follow-up. A later description of the AIM chaplain's role stemming from the author's work experience as senior chaplain at Adventist Information Ministry included three unilateral and six fundamental responsibilities.

Analysis of interviewee perceptions about the AIM chaplain's role was introduced through findings related to 
job training, a chaplain's manual, accountability, and evaluation within the chaplain's department at AIM. Perceptions about the senior chaplain's role were then developed with perspectives stemming from the chaplains themselves, the AIM staff, and the executive steering committee members who were surveyed. Rankings of importance for the AIM chaplains' work of intercession, referral and follow-up, counseling, chaplains' meetings, and administration were reported. Three interesting discoveries were highlighted with intercession receiving the place of greatest importance but least time spent, administration voted least important but second in time spent, and counseling looked upon with lower importance but claiming the most time spent among the six key functions for the chaplains at AIM. Numerous perceptions regarding the six primary functions were further analyzed with evaluations and suggestions from various interviewees presented. The chapter moved toward a close with a comparison of AIM staff and executive committee members' rankings for the chaplain's six central tasks according to perceived importance, and ended with two curious findings discovered from results recorded in table 7 .

\section{Conclusions: The AIM Chaplain's Role}

The Introductory $29^{\text {th }}$ Question

The reader may recall mention of question 29 where interview question flexibility was discussed in chapter 2 . 
Initially placed in the interview instrument as the lead question for section IV, question 29 asked: "What is your understanding of the role of the AIM chaplain?" After a few chaplains had been interviewed the author realized this general question was poorly positioned by coming after the specific questions preceding it, and that it would be better used as an introductory question in section III for the AIM chaplain. The open-ended $29^{\text {th }}$ question was thus re-located in the author's reading of questions for the majority of interviews which followed, in order to learn what first came to chaplains' minds regarding the AIM chaplain's role.

These initial perceptions from chaplain interviewees will now be unveiled as introductions to the author's conclusions for the role of the Adventist Information Ministry chaplain.

\section{Meetings}

Of the six fundamental responsibilities pursued by AIM chaplains, meetings were never mentioned in their reply to question 29 when first asked about their understanding of the role of the chaplain at AIM. Given a universal disdain for boring meetings that do not adequately meet attendants' needs, it came as no surprise that the concept of meetings never surfaced in the minds of the surveyed chaplains when reflecting back upon their role, despite their identification of the meeting's strengths mentioned in chapter 4. The interviewed chaplains did however offer one 
suggestion for consistent adoption by current AIM chaplains and staff which the author especially endorses.

Recommendation: Use Voice Mail and in-house E-mail to its fullest advantages. Tried as an alternative to tying up a group of chaplains' time in meetings laced with announcements, the author placed messages previously reserved for meetings on the chaplains' Voice Mail during the latter months of his service as senior chaplain. This simple procedure offered the same freedom to modify messages as when verbalized in meetings, but allowed for the message to arrive sooner. More importantly, the Voice Mail vehicle gave each chaplain the freedom and flexibility to listen to announcements during times best suited for their working schedules. It also took care of the problem of having to repeat announcements when chaplains missed a meeting.

Because news can be scanned by the eye more quickly than heard by the ear, perhaps sending typed messages through a series of networked computers in the chaplain's department would now be a better solution, provided this technology is currently in place within the chaplain's department at AIM.

Recommendation: Periodically poll current chaplain teams to identify weaknesses and make adjustments as necessary. The author experienced some of the same frustrations voiced by his interviewed peers regarding the 
problems associated with chaplains' meetings at AIM. One constructive recommendation he would like to offer for dealing with the weaknesses of the professional-development segment of the meetings (not to mention all other important aspects of the chaplain's department) is to periodically give the chaplains an opportunity to evaluate the various components of their operations. A wise supervisor would then make appropriate modifications that would likely result in better meeting the varying needs of individual chaplains, which in turn would likely improve team morale.

\section{Administration}

Administration was referred to only once in response to the $29^{\text {th }}$ question, where chaplains were asked about their initial understanding of the AIM chaplain's role. Little wonder it would be ranked last in importance by the chaplain interviewees when compared with their other fundamental responsibilities, as shown in table 6. With administrative duties occupying so much of the chaplain's time as reflected in the second-place ranking given for time spent in this area, the author proposes the following three recommendations.

Recommendation: Employ a chaplain's secretary with regularity. During the author's work experience at AIM, a chaplain's secretary worked part-time to help lighten the load of the chaplain's administrative tasks. There were 
periodic months of time during those two and a half years however when no secretarial help was available for the chaplains. With the documentation and paper work the AIM chaplain was required to keep up with, a secretary seemingly. could have been kept busy full-time. Given the realities of AIM's budgetary constraints, a part-time secretary consistently employed without large gaps between service would perhaps be the most realistic option for blending the challenges of the chaplain's heavy work load and the limited funding available for the chaplain's department at AIM.

\section{Recommendation: Follow-up on fully functioning} chaplains' computers independent of Andrews University. Another approach to the struggle of administrative overload for the AIM chaplain could be introduced by a chaplain interviewee who suggested "having all the information chaplains need on computer." ${ }^{1}$ This was in fact being increasingly attempted during the author's tenure at AIM. In the late 1990s, one might think a proposal for computerized accessability of information for all AIM chaplains is a rather rudimentary idea. However, in the early to mid-1990s, a frequent problem developed in that certain domains of the computers at AIM were not working for months at a time. AIM's documentation programs for chaplains and phone operators alike were linked to the 
mainframe computer system at Andrews. University. A backlog of campus-wide computer challenges apparently kept the computing-center staff very busy. For reasons not entirely known to the author, AIM chaplains received very low priority in the line-up of service calls, despite the fact that the computer center was in the same building and just down the hall from Adventist Information Ministry. Little wonder that two interviewed chaplains called for "a new computer system." ${ }^{1}$ Said another, "A working computer system is needed. . . If this is not possible, other people could help with the administrative part who are not chaplains." ${ }^{2}$

These comments take us back to the need and prior recommendation for a systematically employed chaplain's secretary, given the recurring reality of past computer breakdowns at AIM. But fully functional, networked computers are also needed for the AIM chaplain's department. At the time of the author's departure from Adventist Information Ministry in september of 1994, steps were being taken to develop documentation software for the chaplains' computers that would be independent of the University's mainframe system. If for some lagging reason this has not been fully accomplished to date, the author would recommend such a move be financed and completed immediately.

\footnotetext{
${ }^{1}$ Chaplain \#34, telephone interview by author, April 29, 1994.

${ }^{2}$ Chaplain \#25, telephone interview by author, May 3, 1994.
} 
Recommendation: Adopt spiritual gifts-based assigning of chaplain's fundamental functions: The spiritual gifts approach to dividing up the AIM chaplains' duties for tackling them more efficiently is another recommendation related to the area of administration the author highly supports. Tested during the latter part of his tenure as senior chaplain, the author discovered this plan met with the most success of any methods tried for handling the volume of work set before the chaplains at AIM. As testified to by a chaplain interviewee responding to the question of how their role could be improved, "to base the chaplains' functions on their spiritual gifts and allow them to specialize would result in greater ownership of that responsibility." ${ }^{1}$ In the author's estimation, chaplains participating in the spiritual gifts-based plan for executing their role experienced higher job satisfaction and more effective job performance, which seemed overall to result in a more efficient team execution of the primary responsibilities of the AIM chaplain.

\section{Intercession}

The role of intercession was also mentioned once by the chaplains in reply to question 29. As indicated above, the scant mention of administration and meetings was not surprising given their ranking of last and next to last

\footnotetext{
${ }^{1}$ Chaplain \#44, telephone interview by author, May 1, 1994.
} 
in importance, as revealed in table 6. The author did not, however, expect to see intercession mentioned only once, when this function was voted the most important of all the chaplains' tasks according to the findings for question 24 .

A confusing correlation. If participation in prayer on behalf of others has truly been important to the AIM chaplain over the years, one would think this function would have surfaced in the minds of more chaplains when asked about their understanding of their role in the introductory $29^{\text {th }}$ question. Given that chaplains gave last-place status to intercession in question 26 when asked to rank their functions according to time spent, perhaps the response to question 29 should not be viewed as so surprising.

\section{A parallel observation and recommendation for}

further study. When placed together, though, the findings from these two questions do seem to parallel an observation the author has made from his own spiritual journey and from pastoring other Adventists since 1981: People may talk about the importance of prayer for their Christian life, but in reality may spend comparatively little time in actual communion with God, especially when it comes to interceding on behalf of others. While the author acknowledges a person does not necessarily have to spend a lot of time pursuing something to justify its importance, a correlation between 
persistent, prevailing prayer and significant answers to prayer is readily understood by many mature Christians. The quantity and quality of prayer ministry with other chaplain teams outside of the author's experience at AIM remain unknown beyond the discoveries reported. The author wishes he could have probed more deeply into the ranking of top importance given to intercession by chaplain interviewees, with the hope that this aspect of the AIM chaplain's ministry might be better understood. In his estimation, the realm of prayer ministry at AIM is pregnant with possibilities for enhancing and expanding the outreach of Adventist Information Ministry. It is also an area of personal interest in which the author has a pastoral passion for. However, this is one of the topics revealed in this project report that must be relegated to the domain of recommendations for further study, given the inescapable delimitations of the dissertation.

\section{Recommendation: Implement interviewed chaplains'}

strategies for improving AIM's prayer ministry. The chaplains' overall response to the $22^{\text {nd }}$ question of the interview instrument which asked for a philosophy of handling prayer requests was perhaps stronger than any other reply. As indicated by the volume of comments displayed under the heading of intercession in chapter 4 , the surveyed chaplains had quite a number of suggestions for improving AIM's prayer ministry. The author believes their 
propositions could potentially provide for a more enhanced way of responding to the multiple prayer requests called into AIM's 800-number. He encourages a careful review of these ideas along with implementation of the prayer ministry strategies considered by current AIM staff, chaplains, and phone operators to be the most beneficial.

\section{Referral and Follow-Up}

\section{Moving further into the chaplains' initial} impressions about their role, the functions of follow-up and referral were next in order of increasing mention. Five chaplains identified follow-up and fourteen noted referral when answering question 29. These facets of the role of the AIM chaplain were likened to "a vital link" and "a bridge between media programs and interests and a local pastor," ${ }^{2}$ with a final member of the chaplains' group stating he was reminded each day "to treat every name a sacred trust." ${ }^{3}$ Such comments by the chaplain interviewees illustrate a few of the ways in which referral and follow-up formed a distinct and important association in their understanding of the role of the AIM chaplain. Given the missiological backdrop undergirding the AIM chaplain's creation reported earlier, the author was pleased to see this commentary come

\footnotetext{
${ }^{1}$ Chaplain \#28, telephone interview by author, April 29, 1994.

${ }^{2}$ Chaplain \#18, telephone interview by author, May 3, 1994.

${ }^{3}$ Chaplain \#11, telephone interview by author, May 1, 1994 .
} 
forth regarding referral and follow-up. For a majority of chaplains interviewed, these vital two components of AIM's evangelistic mission had not been forgotten.

The functions of referral and follow-up did not generate the array of input that either intercession or counseling did, perhaps because they were looked upon as basic to the AIM chaplain's role by a majority of the interviewed chaplains. Viewed as non-controversial with very few suggestions volunteered for reform, chaplains regarded the functions of referral and follow-up as the bread and butter so to speak of their role at AIM. However, as important as these two components have historically been for the AIM chaplain, it must be acknowledged that they are not the only pieces of proverbial bread on the AIM chaplain's table.

Are referral and follow-up the bull's eye of the AIM chaplain's target? Not long ago the author purchased an archery target for his son's bow and arrow set. In the very center of the concentric rings is a bright-colored circle known as the bull's eye which marks the spot his young archer aims for and hopes to hit. If the chaplains at AIM were thought of as archers ready to release their arrows, what would be the central bull's eye in their sights? One answer to that question was shared in chapter 3 where an individual contributing to the founding of AIM said: 
AIM is not just a shotgun but rather a bullet with its specific one-point mission, to develop the interests brought to. AIM and develop them to fruition. The primary objective for establishing AIM was to provide a follow-up of interests. ${ }^{1}$

The author believes that all six of the chaplain's fundamental functions work together to accomplish this goal of developing interests unto fruition. While he sees follow-up of interests as a primary objective for the AIM chaplain, follow-up is not, in his estimation, the primary objective or central bull's eye for the AIM chaplain. Advancing the AIM archer's target motif further, the chaplain's six tasks should each be considered a separate ring of a multi-ring target. With that picture in mind, the specific function of follow-up could readily be looked upon as one of the inner circles of the AIM chaplain's target, perhaps the one closest to the bull's eye. But follow-up in and of itself is still not the bull's eye the AIM archers should be aiming for. Consider then these words by another member of the AIM founders' group, while pondering what the emblematic AIM chaplain's bull's eye might best symbolize:

Christianity . . . is maintaining a relationship with Christ while the Holy spirit empowers you and wraps that relationship with pertinent information that deals with your daily living. There has to be a bridge of relationship across which the information passes before it becomes character. What we were doing I felt was that we were throwing information out to people without the relationship. But Christ delivered relationship and information. And that's basically why He came as a person. If

${ }^{1}$ Robert Dale, telephone interview by author, April 27, 1994. 
information was the paradigm from which we needed to work, then He would have simply come with a heavenly display of information. ${ }^{1}$

Applying these words to the chaplain's role at AIM and what the name Adventist Information Ministry ideally implies, information about interests who call AIM with a spiritual request is quickly referred to a local church, for the purpose of engaging church members in a ministry of building relationships and sharing pertinent information with that interest for their spiritual development. That information is promptly recorded at AIM through the chaplain's administrative work. A follow-up ministry conducted at periodic intervals following the initial referral then seeks to ensure that a helpful relationship with the interest has been bridged and is being maintained. With Cummings's commentary still in mind, is it any wonder AIM callers are at times unable to wait days or weeks for their relationship with Christ to begin or move forward? Consequently, callers frequently request what appears to be on-the-spot relationship building. This can take the form of a simple prayer request, providing AIM chaplains and operators with golden opportunities for the ministry of intercession to occur on behalf of the caller. These onthe-spot requests may also require another type of follow-up ministry, where an AIM chaplain provides a short-term 
friendship coupled with Bible-based information in the form of pastoral counseling. Chaplains then attend a weekly meeting to engage in a group ministry of intercession, to process information regarding callers for identifying interests who have crossed enabling bridges into a saving relationship with Jesus Christ, and to terminate from AIM's ministry those who have linked up with Christ and those who will not be assisted by AIM's limited bridges.

The author's recently stated belief regarding follow-up bears repeating here. All six of the chaplain's fundamental functions work together to accomplish the goal of developing an interest's relationship with fellow Christians and with Jesus Christ. While following up interests is a primary objective for chaplains at AIM, it is not the central bull's eye they should be aiming for.

\section{Recommendation: Fire with a definite aim at the} bull's eye worthy of the AIM target. Robert Dale indicated the original objective of AIM was to provide follow-up of interests. Des Cummings advanced that historic concept by identifying how information can successfully be transmitted only when bridged by a personal relationship. However, the author maintains there is something or rather some one higher still, and that is the person of the son of God. If Jesus is the way to God, the truth about God, and the life from God as promised in John 14:6 for all Christian 
believers, then Christ alone must be distinctly set forth as the symbolic central bull's eye for the AIM chaplain's target. After all, He and His nearing return to our fallen world is what Adventist Information Service and Adventist Information Ministry have targeted to proclaim from the day their names were chosen.

As the inspired woman quoted in chapters 1 and 3 said: "Success in any line demands a definite aim. He who would achieve true success in life must keep steadily in view the aim worthy of his endeavor."1 There is one alone who is worthy to be the central target of every human endeavor. "You are worthy, O Lord, to receive glory and honor and power, for You created all things. . . Worthy is the Lamb who was slain." (Rev $4: 11,5: 12$ NKJV). It is therefore the author's conclusion and hope that Jesus Christ be given the honor He deserves at the very center and heart of the AIM chaplains' targeted ministry for following up interests unto salvation.

\section{Counseling}

Finally, it ought to be noted that twenty of the twenty-three chaplains responding to the introductory $29^{\text {th }}$ question about the chaplain's role at AIM referred to counseling by name or in concept. This citing surpassed

${ }^{1}$ Ellen G. White, Education (Mountain View, CA: Pacific Press Publishing, 1903), 262 . 
references to the next most-often-mentioned function of referral by more than 25 percent. Readers should be reminded that chaplains ranked counseling the foremost employer of their time as relayed in their response to question 26. While certain AIM leaders may be tempted to look upon these discoveries as disturbing, repeated findings from this study do point to the fact that counseling was considered a chief ministry for a majority of the chaplains at AIM. The author is convicted that the time is ripe for a united AIM leadership to set forth a positive definition of pastoral counseling and to bless its mission-minded usage within the chaplaincy department of Adventist Information Ministry. To assist with the enactment of that conclusion, he invites current chaplains, staff, and leadership to seriously consider the following ten recommendations for the role of counseling performed by the AIM chaplain.

\section{Recommendation 1: Understand the basic counseling} qualities needed for chaplains at AIM. Counseling at AIM was likened to "talking with someone in depth"1 by one chaplain. The role of counseling for the chaplain took on a variety of shapes such as "involving a crisis with a family, or a person simply looking at their options." ${ }^{2}$ Described as

\footnotetext{
${ }^{1}$ Chaplain \#32, telephone interview by author, May 2, 1994.

${ }^{2}$ Chaplain \#26, telephone interview by author, April 25, 1994.
} 
"mostly listening to what people's problems were," ${ }^{1}$ it was understood that counseling by the chaplain at Adventist Information Ministry was performed "not to give legal advice, but to comfort and offer hope." ${ }^{2}$

Based on the author's counseling experience at AIM, employing good listening skills with caring concern for the purpose of helping callers view their options from a biblical perspective with hope in the Lord were the basic qualities needed for responding to counseling calls at AIM. When proper balance was employed between benevolence and prudence regarding length and frequency of a chaplain's counseling call, a caller's need for spiritual help and understanding was often granted, which in turn conveyed a blessing upon the caller and chaplain alike.

\section{Recommendation 2: Trust in the protection provided}

by the simple disclaimer statement. Readers should be aware that "due to legal ramifications," ${ }^{3}$ AIM chaplains were "instructed to use the disclaimer statement" (see Appendix G), so that callers would understand the guidance they were about to receive was "not professional counseling involving lots of training." ${ }^{4}$ This caution spoken by AIM chaplains at

${ }^{1}$ Chaplain \#43, telephone interview by author, April 28, 1994.

${ }^{2}$ Chaplain \#42, telephone interview by author, May 2, 1994.

${ }^{3}$ Chaplain \#19, telephone interview by author, May 4, 1994.

${ }^{4}$ Chaplain \#27, telephone interview by author, April 26, 1994 . 
the beginning of counseling calls has over the years brought satisfactory understanding and protection for identifying who AIM chaplains are and are not, and what they do and do not provide. The author did not hear mention of any problems associated with the disclaimer statement, either during the course of the phone interviews or during his AIM work experience years, and recommends that this simple statement continue to be used by the AIM chaplains whenever appropriate.

Recommendation 3: Refer to counseling at AIM by the name "pastoral counseling." While "it was reinforced that counseling was not the mission of AIM," " the reality of some form of counseling occurring with a toll-free line connecting hurting callers to pastors in training at the Seminary serving as AIM chaplains was certain. "In view of late night shifts with suicide calls, even referral and follow-up of this involves counseling, " ${ }^{2}$ explained one chaplain respondent. How then should this service performed by AIM chaplains be referred to? Guidance? Spiritual guidance? Spiritual advising? Giving advice? Counseling? Bridging counseling? Christian counseling? Pastoral counseling? Spiritual counseling? Pastoral nurture? All ten of these terms were used by interviewees when describing

\footnotetext{
${ }^{1}$ Chaplain \#28, telephone interview by author, April 29, 1994.

${ }^{2}$ Chaplain \#14, telephone interview by author, April 25, 1994.
} 
counseling done by the chaplains at AIM. The author believes the term "pastoral counseling" most accurately identifies who is providing the service, and what is in fact transpiring: In his opinion, AIM chaplains should not be fearful of using this phrase in conjunction with their disclaimer statement.

\section{Recommendation 4: Further training desired and} guestioned with pragmatic alternatives suggested.

Regardless of the precise label given to this practice performed by AIM chaplains, as one chaplain put it, "inevitably there will be some counseling and talking with someone in depth. However, chaplains need more training here." ${ }^{1}$ The concern for more training was voiced by a handful of chaplains including one interviewee who reminded the interviewer, "As M.Div. students we have only had one class in counseling." ${ }^{2}$ Said another, when it comes to counseling by AIM chaplains "some more training is needed in that parameter, as I felt kind of lost doing it." ${ }^{3}$

To deal with the lack of training, one suggestion from the chaplains favored a less formal approach, such as "take a Learning to Care training seminar to develop

\footnotetext{
${ }^{1}$ Chaplain \#32, telephone interview by author, May 2, 1994.

${ }^{2}$ Chaplain \#46, telephone interview by author, April 27, 1994.

${ }^{3}$ Chaplain \#41, telephone interview by author, April 29, 1994.
} 
listening skills." ${ }^{1}$ One or two other chaplains suggested that AIM chaplains pursue "periodic classwork in counseling" ${ }^{2}$ with a more formal approach in mind.

The author wonders, however, if additional formal training, i.e., taking more counseling classes at the Seminary, would provide the pragmatic answer needed for supplying the advancement many chaplains desired for improving limited skills in counseling. To move beyond the chaplains' disclaimer level of offering simple spiritual guidance, to the heightened level of a trained and licensed counselor, would require at the very minimum a master's degree dedicated solely to counseling.

It is true, as one chaplain put it, that "we can't do what we are not trained to do." ${ }^{3}$ For those few ministerial students who happened to be hired as AIM chaplains before receiving the basic counseling course in their M.Div. program, "a crash course in counseling techniques" ${ }^{4}$ would likely be needed. However, further formal training with graduate-level coursework as the medium for pastoral counseling, beyond that which the M.Div. degree offers ministerial students, is not, in the author's estimation, what is being called for in most instances.

\footnotetext{
${ }^{1}$ Chaplain \#31, telephone interview by author, May 1, 1994.

${ }^{2}$ Chaplain \#35, telephone interview by author, April 25, 1994.

${ }^{3}$ Chaplain \#23, telephone interview by author, April 26, 1994.

${ }^{4}$ Chaplain \#11, telephone interview by author, May 1, 1994.
} 
For the majority of AIM chaplains who wished for "additional training in counseling, listening skills, and verbal communication, " ${ }^{1}$ more pragmatic alternatives are needed.

\section{Recommendation 5: Adopt verbatim-based practicums} with regularity in chaplains' meetings. In response to the interviewed chaplains who felt inadequately equipped for counseling at AIM and desired additional training, the author offers a couple of recommendations. For one, it is believed the practice of using verbatims, if consistently incorporated into the weekly chaplains' meetings, could provide part of the answer for this problem. During his employment at AIM the author recalls how positively each chaplain who participated in a verbatim testified to the help they received from these practicums for sharpening their skills in the area of pastoral phone counseling. Given the entry-level nature of pastoral counseling needed for the majority of calls that come to the AIM chaplain, it is believed a more uniform practice of scheduling weekly verbatims would go a long way toward supplying some of the help needed for the practice of basic pastoral counseling at Adventist Information Ministry.

\section{Recommendation 6: Remember the spiritual-gifts}

approach. Another recommendation that could assist chaplains who were uncomfortable with their level of

\footnotetext{
${ }^{1}$ Chaplain \#33, telephone interview by author, May 2, 1994.
} 
training for counseling at AIM is that of the spiritualgifts approach for assigning chaplains their duties. It is imagined that the chaplains who had a degree of discomfort with counseling had a gift in another area of fundamental responsibilities. In the future, why not have such chaplains take on additional assignments in the area of their giftedness, while giving up most of their counseling obligations to a fellow chaplain who is gifted in pastoral counseling and willing to make such a trade? As wisely expressed by one interviewee, "Each chaplain must know what his or her abilities are in this area, "1 and he or she would do well to exercise them accordingly.

\section{Recommendation 7: Hiring considerations. With} counseling being one of the key responsibilities of the AIM chaplain, identifying giftedness or at least a basic comfort level with providing spiritual guidance during a chaplain's job interview could be a helpful factor in hiring student chaplains for employment. Another suggestion for preventing future uneasiness with counseling at AIM would be to try to hire more seasoned pastoral students who have had additional experience in this area. When this would not be possible given Seminary student availability, an alternative would be to hire one student chaplain per chaplain team who is majoring in counseling, such as from the school of Education

\footnotetext{
${ }^{1}$ Chaplain \#26, telephone interview by author, April 25, 1994.
} 
at Andrews University. During the author's term at AIM, one chaplain team was complemented with a seasoned pastor pursuing both his M.Div. degree from the seminary and an off-campus degree in counseling through Liberty University. This combination provided just the right blend of chaplain insights needed when a more serious call for pastoral counseling arrived or when a follow-up call of this sort was identified and needed to be assigned.

\section{Recommendation 8: Greater availability for taking}

calls, and pagers needed. The author is not alone in suggesting that availability for taking call by AIM chaplains be more seriously considered and expanded. As expressed by an staff member, they too wished chaplains would provide "greater availability around a wider span of time for accepting chaplains' calls."1 It is no more possible to predict when a need for pastoral counseling at AIM might arise than it is to schedule an appointment for a woman's natural delivery of her baby. Consequently, one chaplain interviewee also suggested that AIM chaplains "give consideration to round-the-clock staffing of chaplains, in light of the times when no chaplain is on schedule." 2 Unless all the AIM chaplains on a given team are reasonably comfortable with or gifted in pastoral counseling with one

${ }^{1}$ Chaplain \#86, telephone interview by author, April 28, 1994.

${ }^{2}$ Chaplain \#18, telephone interview by author, May 3, 1994. 
of them always available for call, callers' needs will very likely go unmet when opportunities present themselves, and a degree of dissatisfaction with this area of the chaplains' ministry at AIM will continue. AIM would thus do well to invest in some electronic pagers for chaplains to wear and respond to when on call.

Recommendation 9: Cautions regarding regular callers and caller ID suggested. As one chaplain interviewee cautioned, counseling by AIM chaplains "over the phone is not wise. . as the tendency is to form an attachment with the same person." ${ }^{1}$ While questioning the wisdom of counseling "over the phone" seemed strange given that the telephone has been the sole communication medium employed by Adventist Information Ministry, the propensity toward fastening on to a particular chaplain by people known as "regular callers" 2 was not a misnomer. As reported by one chaplain, "A handful of people were regular callers whom we took no more calls from." ${ }^{3}$

In response to concerns developed over regular callers who began to monopolize an AIM chaplain's time when allowed to do so, repeat callers occasionally became forbidden to continue calling AIM. With the chaplain teams

\footnotetext{
${ }^{1}$ Chaplain \#47, telephone interview by author, May 2, 1994.

${ }^{2}$ Chaplain \#15, telephone interview by author, April 25, 1994.

${ }^{3}$ Chaplain \#43, telephone interview by author, April 28, 1994.
} 
the author was a part of, refusing certain regular callers' telephone calls up front was not always possible either, given name and voice disguises occasionally employed by forbidden callers. Caller identification and its ability to block unwanted incoming calls has become further developed since the author left AIM. This is a technological way of better screening regular callers, and should be considered for the AIM phone system if not now being utilized. A better method for handling habitual callers involving greater accountability on the part of the chaplains themselves may also still be needed at Adventist Information Ministry.

\section{Recommendation 10: Work through the likelihood of} ongoing misunderstandings with chaplains' counseling at AIM. During the period of his work as senior chaplain, there seemed to be an attitude circulating at AIM regarding counseling by chaplains, that at times moved beyond a level of appropriate concern and came across as inordinate fear. It was shared with the author that such fears were not inflated but valid, based on potential lawsuits in an increasingly litigious North America. Thus it was explained that individuals on the AIM executive steering committee who felt this way were justified in their heightened concerns. The author did not dispute the basic rationale behind these concerns back then, nor does he now. 
With this backdrop of spasmodic response regarding counseling performed by the AIM chaplain in mind, the high ranking given to the importance of chaplains' counseling by influential AIM committee members (see table 7) seemed odd. Viewing the AIM committee's ranking of chaplains' counseling as second in importance contrasted with the AIM staff's placement of it as fifth, and remembering that AIM chaplains voted counseling the number one employer of their time yet ranked it fourth in importance, all added up to a blend of widely differing perspectives regarding the role of counseling for the chaplain at AIM. These multiple viewpoints collectively suggest that current AIM leadership, staff, and chaplains should meet together someday soon to work through the likelihood of ongoing misunderstandings in the area of counseling performed by the chaplains at Adventist Information Ministry.

Question 28: Considering the AIM Chaplains' Contributions

Chaplains' fundamental functions validated. The open-ended $28^{\text {th }}$ interview question inquired of each chaplain being surveyed, "What has been your greatest contribution to AIM while serving this organization?" This was the final question of section III focusing on the AIM chaplain. It received a solid response with $92.3 \%$ of the interviewed chaplains granting a reply. The author tallied each contribution mentioned and discovered a majority of the 
chaplains referred to one or more of the fundamental responsibilities by name when they spoke of their personal contributions to Adventist Information Ministry. Their testimony was viewed in part as providing support for the validity of the author's choices of the six fundamental functions identified for the AIM chaplain.

Areas chosen for recommendations confirmed. The chaplain interviewee contributions that were mentioned the most in reply to question 28 were abilities in counseling followed by administrative gifts and referral of interests. The author noted the citing of these three contributions lined up exactly with the order of the first three functions chaplains reported spending their time with according to the results from question 26. That chaplains have made substantial donations in these three areas has undoubtably been of benefit to AIM, given these three domains are where the majority of their time has needed to be spent to get their job accomplished. This finding also seemed to confirm the author's recommendations ascribed to the functions requiring the most amount of time for the AIM chaplain to perform.

Should the practice of hiring primarily seminary students with a passion for souls to serve as chaplains at AIM be preserved, the important work of interest referral should carry on successfully. It is also believed that future chaplain teams must continue to employ individuals 
gifted in the area of administration, if the documentation required for referral, follow-up, and counseling is to be maintained. Findings from question 28 further remind us that AIM chaplains have demonstrated they exist for more then referral and follow-up as a few interviewees believed. The fact that counseling was directly or indirectly mentioned slightly more than any other contribution when replying to the 28 th question underscores the reality of its place at AIM. It is thus the author's hope that the interview results related to the primacy of chaplains' counseling will stir AIM personnel to seriously study how this dimension of the chaplain's ministry could be enhanced to further the mission of Adventist Information Ministry.

\section{Additional findings and dissertation limitations.}

Additional findings from question 28 revolved around contributions made to AIM beyond the fundamental duties described for the AIM chaplain's role. For instance, a couple of chaplains expressed how their role with Hispanic ministries had blessed AIM. Another two chaplains referred to employing their gifts on behalf of morale-building among AIM employees. While the author wishes he might have further addressed some of these expressions of the AIM chaplain's role, limitations for the dissertation were necessary as explained in the first chapter. 
A confession about upgrading. There is, however, one additional aspect of the chaplain's work at AIM within the boundaries of this report which the author senses he should have pursued. It was mentioned in response to the $28^{\text {th }}$ question by a chaplain interviewee who described his greatest contribution to AIM as having a "burden for upgrading and inviting people to study the Bible." ${ }^{1}$ With this burden in mind, the author has pondered a like answer given to the similar $31^{\text {st }}$ question by an AIM staff member who signaled: "Answering call questions in a satisfactory way and upgrading" ${ }^{2}$ was the chaplains' most significant contribution to AIM.

"Upgrading" has been a phrase used at AIM in reference to a chaplain or phone operator tactfully inviting a caller to look a step beyond their perceived felt need(s), to ultimately sense a spiritual need for Jesus Christ as personal saviour and Lord in their life. The author recognizes he could have developed the issue of upgrading in the interview instrument, for the purpose of gleaning helpful insights into this important dimension of the phone operator's and chaplain's work at AIM. He regrets that it was overlooked.

${ }^{1}$ Chaplain \#44, telephone interview by author, May 1, 1994.

${ }^{2}$ Staff \#86, telephone interview by author, April 28, 1994. 


\section{Summary of Chapter 3}

Christ's Great Commission provided the cornerstone missiological foundation upon which Ellen white reminded the Seventh-day Adventist Church of the importance of making evangelism and evangelistic follow-up its most important work. The General Conference Presidency and North American Division Church leadership gave precedence to renewing the priority of evangelism and proper follow-up during a period of evangelistic complacency within the denomination.

The advent of telephone outreach some fifteen years in advance of Adventist Information Ministry was followed by the development of the computer, which became known as "the tool of the decade" in the eighties. Chronologically speaking, these foundational tools surrounded discussions of potential approaches to communication for the seventh-day Adventist Church in North America along with advancements for evangelism outreach pondered by the NAD Tools Committee.

The Institute of Church Ministry and the Computing Center located on the campus of Andrews University were two key institutional foundations that merged resources for a prototype toll-free answering service and follow-up program. A visionary plan from the leading personnel associated with their merger was conceived, promoted, and sold to It Is Written, but fought against at higher church levels.

These various foundational factors combined together to give birth in May of 1982 to Adventist Information 
Service, which was re-named Adventist Information Ministry within the first year of operation. In looking back, the future looked bright for AIM.

\section{Conclusions: AIM's Foundations}

For close to twenty-five years the author lived within a twenty-five-minute drive of the mighty columbia River, the biggest river of water west of the Mississippi. He sail-boated and water-skied on it, fished and swam in it, drove by it and over it hundreds of times. For the casual observer, pinpointing the headwaters of a major river like the Columbia is not an easy thing to do, given the many streams and creeks that could be traced back to their own beginnings. Are the largest streams of contributing water what really makes the river? At what point do the smaller creeks create a contribution worthy of consideration? And what about underground sources which may provide a very substantial donation of water to the river, yet go unnoticed and unreported because they remain unseen to the naked eye or unsophisticated detection devices?

\section{A Variety of Foundational} Sources

In parallel with the many sources that make up a roaring river, this dissertation documented a number of foundational statements, formative ideas, technological inventions, and important institutions birthed in advance of A.I.S./AIM that together contributed to the beginnings of 
Adventist Information Ministry. The confining scope of this project provided for many but certainly not all of the historical/missiological factors giving birth to the cutting edge, mission-minded organization. A number of these various ingredients reported on were granted a heightened degree of credibility from the early publications uncovered about AIM's beginnings, which were highlighted in the final section of chapter 3 .

No Single Human Being Should Be Thought of as the Founder

The variety of foundational sources recorded in this dissertation did lead to making one fact quite clear: The delivery of A.I.S./AIM was hardly the result of any one human being's work. The author therefore concluded that previously spoken testimony indicating otherwise must be viewed as untrue as well as arrogant. The "Personal Touch of Adventist Information Ministry" slide and cassette tape presentation produced in conjunction with the NAD Church Ministries Department in 1987 was one such example discovered by the author containing misleading and biased reporting regarding AIM's founding that was unfortunately circulated throughout North America. ${ }^{1}$

${ }^{2}$ The audiotape remarks and accompanying brochure with written narration for the fifth slide of this particular presentation stated: "Dr. Robert Moon, assistant to the president of the university, is the founder and director of AIM" (emphasis supplied). "THE PERSONAL TOUCH of Adventist Information Ministry." 
The Untold Story: God's Hand

Guided the overall Plan

The author has one additional conclusion associated with the excavation of AIM's roots exposed in chapter 3 to bring to the dissertation. It is his studied belief that there remains a governing source for the river of Adventist Information Ministry's foundational story that fittingly deserves to be expressed. Divulged in a humble reminder of the church's unseen but believed to be most powerful resource for shaping Adventist Information Ministry's beginning, one of the handful of founders proclaimed:

The untold story is the way it all came together, not by man, but by the working of the Lord. Being on the front lines as the project developed, I was thrilled at what the Lord would do next. He arranged for the right computer program, equipment, staffing, and the support from the officers of Andrews and the church to be there at the right time. Each day the answer to prayer could be seen as each hurdle was removed to make the system work. Looking back, I can see that the Holy Spirit had a hand in the overall plan. . . . The rest is history. ${ }^{1}$

\section{God at the switchboard}

With the concluding assertion that God has been the real author of Adventist Information Ministry, sharing a few "God at the switchboard" narratives revealed by AIM pioneers may help believers and doubters alike see that God has been more than present at AIM. Craig Willis related the following story during his interview:

${ }^{1}$ Lowell D. Witz, "A.I.M. History," letter to the editor, Focus, Summer 1993, 2 . 
Lester Jones was a student at Andrews who had finished his M.Div. and was pursuing his doctorate. He was working at the university farm to get some exercise when I learned about him. I asked my secretary to phone and request he come to AIM for an interview. He had not even heard of AIM and was a little hesitant, but we got him over here and when he heard what we were doing he thought it was great and said he would consider it. He ended up coming to work as our senior chaplain at AIM.

One day he was working along booth 16,17 and 18, which is where we had our follow-up quarter. In the days of the old phone system when line 1 was busy, it would trip down to line 2 and so on down through the line. This is where we became convinced that God was at the switchboard directing calls to just the right phone operators and chaplains. On this particular day, Lester received a call from a married woman whom as I recall was a bar maid in a town he used to pastor in, with a last name he'd never heard of.

As he spoke with her he asked if she would like to be referred to one of our representatives in her area. She then asked: "You're a Seventh-day Adventist, aren't you?" "Yes, I am," Lester said. The women then revealed: "I used to talk with an Adventist minister in my town. His name was Lester Jones." Suddenly it dawned on Lester who this woman was and that he had counseled her as a single woman. He had not recognized her earlier in the conversation because of her married name, but it all fit together now! As the woman concluded her comments, Lester said to her: "Let me tell you a little miracle, I'm Pastor Lester Jones."

Willis observed, "It was uncanny how God connected

AIM phone operators with callers. This sort of thing

happened on a frequent basis." Citing another illustration,

Willis echoed more about God being at the switchboard:

One of our AIM volunteers was a retired head of the industrial arts department here at Andrews by the name of Joe Galusha. He had not served more than a month here, and had recently been told a few stories of how God directs the calls at AIM. On a Sunday morning call-in at AIM, Joe received a call on his phone Iine from a person he recognized as being an old school buddy he had not seen since grade school days! Joe came right over to Craig 
after the call and asked: "You know how you were telling me recently about this idea of God at the switchboard? Well, a man just called me, and of all the booths at AIM this call could have come to, here was an old chum who called me whom I was best of friends with as a kid, but had not talked with since the sixth grade!" We've had that type of thing happen over and over again at AIM.

The stories could go on and on and would be appropriate to tell for the purpose of demonstrating how these experiences were much too frequent to be interpreted as mere coincidence. But given that the purpose of this dissertation is not about trying to empirically prove God's existence at AIM, perhaps just one more brief encounter displaying God's guiding hand should be told. The following story does illustrate how a Power beyond what human beings could ever display was at work in the little details of an out-of-the-country caller who dialed a foreign student who was no doubt missing her homeland while at work at Adventist Information Ministry. As related again by Willis:

When AIM was first establishing the Canadian Iine which was approximately one tenth of the population and call volume of the United States, we got a call from a lady of German descent who was then living in Canada. The Lord worked it out for the call to come right to the booth of a German student at Andrews University who was also working at AIM. Interestingly enough, this German lady was soon going to be relocating. To the amazement of the foreign student working at AIM, this lady was moving to the student's home town in Germany!

Marveling at the astounding timings associated with such providential workings at Adventist Information Service/Ministry, Des Cummings, Jr., exclaimed that these "God at the switchboard" encounters totally inspired him 
as well. Cummings exuberantly declared during his telephone interview with the author:

Those timings became so rich that they just caused a buzz. That was the thing that fired me and every day inspired me. You couldn't explain the Divine appointments and the series of events. ${ }^{1}$

\section{Summary of Chapter 2}

With the need established to conduct some type of survey for gathering information from multiple sources for this dissertation, Dillman's Mail and Telephone Surveys: The Total Design Method was chosen as a standard for the entire interview process. This method emphasized affecting response and survey organization as the main components of its philosophy. For the purposes of this project, it was decided that the advantages of a telephone interview outweighed those of a mail survey. With guidance from his advising committee, the author constructed an interview instrument with consideration given to key factors addressed by the Total Design Method. A pilot interview was conducted by telephone and a debriefing session revealed the interview instrument and interviewer were clearly understood. Despite some setbacks from electronic deficiencies and the author's inability to make contact with twenty-six prospective interviewees, phone interviews were completed with sixty-two persons who collectively provided essential input for the major topics of the dissertation.

${ }^{1}$ Des Cummings, Jr., telephone interview by author, May 8, 1994. 


\section{Conclusions: The Pilot Phone Interview and the Interview Instrument}

The Pilot Phone Interview:

Pretests Were Needed With

People Not Working at AIM

The designer of the Total Design Method believed an integral ingredient of successful phone questionnaires was the pilot performance of the instrument. He stated: "It is absolutely essential that telephone questionnaires be tested over the telephone." ${ }^{1}$ The dissertation author agreed with Dillman's concept in principle but did not adequately put that belief into practice. While some of the electronic problems surfacing after his solo pretest would likely have been eliminated had more pilot tests been pursued, an even greater problem went undetected as a result of limited pretesting. The problem? The interview instrument contained far too many questions.

The author should have picked up on this problem when the debriefing occurred for the one pretest conducted. As identified in table 3, interview length was addressed by the interviewer. The interviewee admitted his work with AIM guaranteed a high level of interest regardless of interview length, but the author breezed by this important testimony. Had individuals beyond AIM's in-house staff been considered and employed for a few additional pilot phone interviews, the author might have caught on before it was too late.

\footnotetext{
${ }^{1} \mathrm{Dillman}, 229$.
} 
An Assortment of Questions

Outside Stated Scope

of Dissertation

In the introduction to the phone interview (see page

2 of the instrument) the author stated to each interviewee:

"My topic revolves around Adventist Information Ministry,

and the role of the AIM Chaplain." Looking back at the

questionnaire, the large assortment of 58 interview

questions (including those listed alphabetically) did not

always stay within the boundaries of the stated topic. Upon compiling all the interview data it seemed to the author that enough information had been gathered for the writing of a couple of dissertations, in light of the recommended number of pages for this type of project report. On the other hand, the input received for Section IV's questions regarding AIM leadership roles was often sparse and at times rather negative. In the author's judgment, the combination of these factors rendered most of section IV plus the first three questions of section $\mathrm{V}$ of the interview instrument as inappropriate to report on for this dissertation.

What a Redesigned Interview

Instrument Would Change

Were the author to redesign the interview instrument, the following changes would likely be made. In Section II: Eliminate "Theological and" from the title and eliminate question 10. Reducing the title to "AIM's Missiological Foundations" would have more accurately 
identified the bulk of questions within this section. Question 10 would be deleted because it was too general and therefore difficult to answer. The idea behind this question was sufficiently expressed in question 11 . In Section III: Combine questions 18 and 19 because they were too similar as stated in chapter 4 .

In section IV: Relocate this section's opening question (\#29) to serve as the introductory question for section III dealing with the AIM chaplains, which was in fact implemented and reported on. Move questions 30 through 34 to the end of section III, with question 31 replacing question 28. Eliminate questions 35 through 43 , because asking just three questions for each of these three leadership roles did not generate enough objective material to justifiably comment on as previously stated. From an organizational standpoint these modifications would do away with the fourth section. In section $V$ (which would be relabeled Section IV): Eliminate questions 44 through 46 for the same reasons identified for questions 35 through 43 . Re-work questions 47 through 49 with the hope of receiving more meaningful responses than those which are reported in Appendix C. Finally, eliminate questions 50 through 53, given the decision identified below regarding the agency group.

For reselecting which groups of individuals would be interviewed, the authors of How To Conduct Surveys: A step- 
by-Step Guide put it well:.."When you decide to conduct a survey, you almost always have a fairly good idea of which people you want to include. The trick is to get enough people whose views count." ${ }^{1}$ Given the particular topics determined for this dissertation, AIM founders and AIM chaplains would unquestionably be included. The author would again seek out the broadening insights from AIM staff as well as the steering committee group for the task at hand. In all likelihood, the agency group would be dropped from the survey along with the group of pastors. The limited response gleaned from the agency interviews did not fit into the two topics focused on for the dissertation. While the pastors' input could have potentially been quite helpful for this study's stated purpose, there was not an adequate number of interviewed pastors who were knowledgeable enough about AIM to offer the kind of substantial replies needed for a valid group view. Fink and Kosecoff knew what they were talking about.

Perceived Benefits from a Revamped Interview Instrument

Therefore, a revamped questionnaire would be reduced by 19 questions for a total of 39 questions in all, which would have been more in harmony with Dillman's call to "reduce costs to the respondent by making the task appear

\footnotetext{
${ }^{1}$ Fink and Kosecoff, 54.
} 
brief" as recorded in table 1 of the dissertation. A reduction such as this would have brought a greater degree of consideration to busy interviewees who in many cases were asked too many questions for the limited time made available. It is also believed this one-third reduction of interview questions would have helped corral the multiple topics inherent with the instrument the author employed. This in turn might have resulted in a better response for the many qualitative-type interview questions still being asked, and possibly helped reduce scant replies given by some of the telephone interviewees for certain questions.

Questioning whether a Redesigned Instrument Would Have Helped Certain Interviewees

From another perspective, the author wonders if making changes in the interview instrument would have really made much of a difference for some of the people interviewed. A few comments about question flexibility introduced earlier in the dissertation would be appropriate here. On p. 37 the author stated that "not all of the interview questions assigned to a particular group were able to be asked." One example of this challenge occurred when an interviewee, upon receiving the author's initial call, set up a thirty-minute appointment for an interview at a specified time on the following day. When the author called the next day at that time, he was told the person was "unavailable." That person kindly called the author back 
the next day but said he was. "very booked" and asked the author to shorten the interview to ten minutes. ${ }^{1}$ (See Phone Log in Appendix E.) In instances such as this about all the author could do was graciously comply and make the best use possible of the limited interview response.

On the opposite end of shortened interviews were certain interviewees who gave very lengthy replies to openended questions that seemed to interest them. Thus the author had to quickly choose which questions to skip and which to ask when the time allotted for the interview began to run out. Despite the author's attempts to provide an overview of the interview instrument at the beginning of each interview and his endeavors to politely direct conversation throughout the survey so that each question could receive a proper amount of time for an adequate reply, perfectly timed responses were seldom received by interviewees with strong personalities and/or busy schedules. Perhaps the inevitable occurred with some of the persons interviewed in light of the qualitative-type telephone interview given to choleric leaders who understandably had a limited amount of time, or a lot of insights to give back in return.

${ }^{1}$ Committee \#50, telephone interview by author, April 29, 1994. 
A Final Conclusion: Jer $6: 16$ and Rest

The descending journey down a mountainous project has neared its end with arrival at a final conclusion for the dissertation. It seems fitting to finish this study of AIM's foundations and chaplains near its point of beginning, with the ancient words of Jeremiah encountered early in the introduction to this report:

This is what the Lord says: stand at the crossroads and look; ask for the ancient paths, ask where the good way is, and walk in it, and you will find rest for your souls. (Jer $6: 16$, NIV)

Having stood and looked at the crossroads of Adventist Information Ministry at length, having asked enlightened pioneers about AIM's beginning paths, having surveyed chaplains' pathways and walked them personally, the author admits rest has not yet arrived. There still remain more of life's mountains ahead to climb and descend. But having communed with God at the switchboard, having walked with The Target of life, having assurance God's terrestrial research is terminal, rest will arrive someday soon, on a hilltop, with no more strife. 
APPENDIX A

ADVENTIST INFORMATION MINISTRY OVERVIEW:

AN EARLY 1990S PERSPECTIVE 


\section{Adventist Information Ministry Overview: An Early 1990s Perspective}

Adventist Information Ministry (AIM) is a branch of the North American Division (NAD) of the Seventh-day Adventist (SDA) Church. A non-profit organization, AIM is primarily funded by the NAD, by media agencies who use AIM, and by union and local conferences of the SDA Church in North America. ${ }^{1}$

AIM functions as the central phone-answering and coupon-processing service for SDA media outreach in North America. It assists the church's evangelism by processing requests for literature, by referring persons interested in a visit or studies to the local church or other appropriate agency as quickly as possible, and by periodically following up on the progress of these interests. ${ }^{2}$

Through its $800-$ number which has a present capacity of handling twenty-four simultaneous inbound calls, AIM takes orders for materials on behalf of various Christian distributors and handles calls which initiate a pastoral response from AIM chaplains. AIM also fields nationwide and regional-based inbound calls for agencies with short-term

"AIM Brochure, "What Is AIM?" and "Who Sponsors AIM?" distributed at the General Conference Session in Indianapolis, Indiana, June-July 1990.

${ }^{2}$ Adventist Information Ministry Employee Handbook, "Introduction to AIM," October 1993. 
needs and assists selected evangelistic agencies by seeking donations on their behalf through outbound phone lines. ${ }^{1}$ The AIM office is located in southwest Michigan on the campus of Andrews University in the Information Services Building, with the AIM Director's office positioned on campus in the Administration Building. Although AIM utilizes the Andrews payroll system and other university services, it is not a university department. ${ }^{2}$ AIM employs ninety-one people, eighty-five of whom work in a student status capacity, with the remaining six persons comprising the in-house AIM staff. ${ }^{3}$

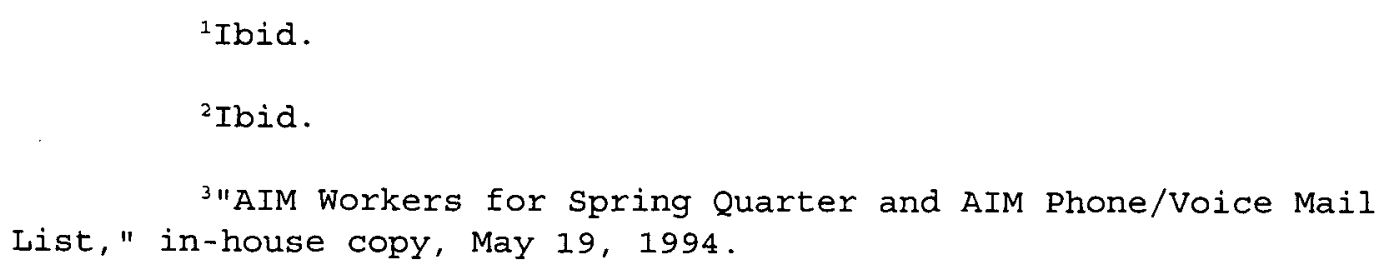




\section{APPENDIX B}

PRELIMINARY PROPOSAL TO IT IS WRITTEN BY ANDREWS UNIVERSITY TO PROVIDE LISTENER REQUEST

PROCESSING, INTEREST FOLLOW-UP, AND

DONATION PROCESSING SERVICES 
PRELIMINARY PROPOSAL TO IT IS WRITTEN BY ANDREWS UNIVERSITY

TO PROVIDE. LISTENER REOUEST PROCESSING, INTEREST FOLLOH-UP, AND DONATION PROCESSING SERVICES

\section{Introduction}

Andrews University's Institute of Church Ministry and Computer Center have combined resources to provide a service designed to assist mass media entities of the Church in fulfilling their mission. This service includes the following activities:

1. A Watts line (nation wide tol1-free) answering service.

2. Computer Support Services for personalized mass mailing and materials distribution.

On June 17, 1981, Andrews University presented a proposal to the officers of It Is Written that was designed to confront the following problems:

1. Unsatisfactory Telephone Service. Currently it Is Written is operating a volunteer telephone answering service in the cities where the programs are aired. The problems with this method are:

A. Limited Calling Time. Operators are on duty for a Timited time span. Therefore, spillover calls (calls which occur at later times) are not serviced.

B. Satellite and Cable Broadcasts. It is impossible to provide telephone service for satellite and some cable broadcasts because these programs may be aired in cities where there is no Adventist church, therefore no available local telephone number. Secondly, satellite broadcasts reach many remote areas simultaneously making it impossible to list local numbers for each area. Thus, a national number is the only feasible a) ternative for providing telephone service.

C. Difficulty in Obtaining Operators. In some cities, such as New York, the program is aired late at night. This makes it difficult to obtain volunteer operators, for reasons of inconvenience and personal safety. Providing operators for other hours or the Sunday broadcast is an ongoing struggle 
frought with many problems. Add to this the lack of training in telephone interviewing techniques, and one begins to comprehend the scope of the problem.

2. Delayed Responses - Basic to building a relationship with a viewer is the ability to del iver your offer to his/her home as quickly as possible. Currently the books that are requested by viewers take 6-8 weeks to arrive at the viewers home.

3. Lack of Evaluation - One of the greatest harriers to effective follow-up is the lack of a system for evaluating the level of interest that the individual requesting the book/books has in receiving a visit from a pastor or church member. Therefore, pastors constantly complain about the level of interest they find when making a visit. This results in a passive or negative attitude toward names that are sent to the local church.

4. Inadequate Follow-up - If a viewer is to become a church member, he/she must develop a growing relationship with Christ and the local Seventh-day Adventist congregation. Therefore, personal follow-up is vital to the goal of It Is Written. Currently pastors complain about receiving outdated names. A system for monitoring a viewers growth and local church follow-up is a prerequisite to achieving the goal of baptism.

After reviewing the proposed telephone materials packaging and shipping strategies, the officers inquired about the possibilities of letter writing and receipting services. At the request of the officers, this prel iminary proposal includes a 7 ist of services that will encompass many of the telephone, shipping, and letter writing-receipting needs of It Is Written.

The proposal is organized according to a three phase plan suggested by the officers of It Is Written. Phase I includes the Watts line telephone answering and follow-up services. Phase II includes packaging and shipping services. Phase III includes letter writing and receipting services. Each phase includes the services of the previous phase. The phases are described in the following narrative, and each step is graphically illustrated on the enclosed flow chart. 
PHASE I

Telephone Answering Service

The telephone answering service utilizes seminary students and/or spouses as operators. These individuals are referred to as service representatives in the remainder of this proposal.

Five functions are encompassed in this phase. They are:

1. Training of Service Representatives.

2. Request Processing.

3. Follow-up Services.

4. Report Generation on request.

5. Computer Processing.

\section{Training of Service Representatives}

Andrews University has a unique resource for quality 1 abor to assist in the functions necessary to quickly place products and information in the hands of 1 isteners. There are many wives of seminary and graduate students who will be working in the future for the Seventh-day Adventist Church, who need jobs to supplement their income. Using these individuals will serve a dual purpose, first it will provide quality 7 abor at very reasonable costs, and second it will involve them in a radio-television ministry in a way that will promote their continued involvement when they return to the field.

Each person who is a prospective service representative will complete a job application form which, in addition to the normal types of information, provides a place to indicate why they would want to be involved in this type of ministry (Note Step 1 page 1 of the flow chart).

After submitting the application, an appointment will be made for a personal and telephone interview (Step 2). The reason for the telephone interview is to assess their phone mannerisms and voice quality. Those who do not have adequate phone mannerisms will be directed into types of activities which do not require meeting the public over the telephone (Step 3.)

Those who have acceptable phone mannerisms will be placed in a workshop where they will receive training related to how they should respond to the various types of requests that will come over the phone (Step 4). This training will be designed in cooperation with It Is Written. At present, the training is based on the Interest Coordinator Training 
Manual developed by Arlys and Eldon Walters. Following the classroom training, the service representatives will have 1 aboratory training involving use of phones and computer terminals (Step 5). The efficiency gained through this training program will be evaluated in an interview following the training (Step 6). Those who meet an acceptable criteria will become phone service representatives (Step 8). Attempts will be made to place the others, if any, in jobs which do not involve direct contact with the public.

The mannerisms of the service representatives handling phone requests will be continually monitored, and additional training will be provided on a periodic basis to help them maintain and improve their effectiveness.

\section{Request Processing}

When an individual calls on an 800 number, one of the phone service representatives will answer, "You're in touch with, (Name). How may I help you?" This request should initiate a response as to why the individual is calling. One of the first requests will be for the person's telephone number so the service representative can call back if necessary.

Research conducted by The Institute of Church Ministry indicates that almost all individuals are willing to provide this number which will give us positive identification, that can be used later in evangel istic reports and market profiles.

The information collected will include data related to: The program viewed, the station the program was on, date the request was made, product requested, whether a first time viewer, and how they 1 iked the program. This information will be kept in such a manner that mul tiple requests from week to week can be monitored. When the days activities are complete, this information will be processed to generate shipping labels and summary reports.

Normally, information will be entered directly onto the computer via a CRT terminal during the time that the service representative is obtaining information. If for any reason this is not possible, there will be a back-up procedure using forms to collect the information so it can be entered on the computer later that day or evening. At the end of each day, all requests for special products will be processed by the computer and 1 abel s generated with the product offer number on the 1 abel. For each product that is shipped, the labels will be pre-sorted to zip-code order to reduce mailing costs. 


\section{Follow-up Services}

Andrews University is prepared to provide the unique followup services listed below. These services are graphically displayed on page 6 of the flow chart.

List to Pastors of Quality Interests - A list of quality interests indicating the date thats the request for a visit or other service was made will be mailed to pastors within 48 hours of the time the request.s are made. In cases where a request is urgent, the pastor will be telephoned. The copies of these lists can be sent to the conference or It. Is Written if so desired. Furthermore, the budget allows for 10,000 follow-up calls of 3 minutes in length. These calls would be made by $A$. U. pastors trained to examine the interest "level of the individual. After the quality interest has been evaluated, and only then, will pastors be called to apprise them of interested persons and to notify them that they will be receiving an interest 7 ist by mail. Pastors will be asked to report back regarding their visits by means of the 800 number at which time the individual records will be updated. The long range goal is that each church in the North America Division will be assigned zip codes or, where there are no churches in the regions, attempts will be made to identify a service representative who would be willing to visit interests (See Steps 61-74).

One unique advantage available only through Andrews University is that the wives of future pastors and graduate students who become workers for the church, can later be field representatives to ensure that there is rapid followthrough. In other words, the work at Andrews University will help build a follow-up network which should increase the effectiveness of future field contacts in a way that will result in more souls.

Regional Coordinators - Conferences that wish, may hire seminary students as regional coordinators to work with pastors and encourage them to make timely visits. This could involve:

A. Contacting pastors by telephone with interests that seem to be of very high quality.

B. Following-up a week to ten days later with the individual to determine if a visit has been made.

C. Re-contacting pastors based upon information to indicate that the person is still wishing a visit, or that they have been visited and the type of response they have toward the visit.

D. Informing pastors of special personal needs, such as death in the family, etc., where a minister may 
be of unique help.

E. Becoming personally involved with some of the quality interests through the mail and the tel ephone.

F. Have pastors use the 800 numbers on week nights to report the results so that the interest file can be updated.

G. Inform conferences of areas where individuals have interest, but no follow-up has been initiated. This would enable the conference to take appropriate action.

Identifying Repeat Interests - Data will be kept on how often a person calls, and the various products they have received up to the last six products. This will be based on positive identification available through obtaining their phone number. At a set criteria point, the individual's name will be advanced to a quality interest file.

Evangelistic Follow-up - When evangel istic efforts are planned in an area, it will be possible to provide lists of persons in appropriate zip-code regions who have requested information within a given time, and indicate the type of interest they demonstrated.

Special Interest Follow-up - Individuals who show interest in special topics, such as nutrition or heal thful living, might be identified during the phone conversation as persons who would be interested in attending a nutrition workshop or a 5-day plan. This could be included on their record. When there are adequate numbers in a region to make such a program desirable, the pastor can be notified with the 1ists of names.

The appropriate use of follow-up services with It Is Written can greatiy improve the effectiveness of this television ministry and help pastors understand the importance of these interests to their soul-winning programs.

\section{Report Generation}

It is possible to provide a variety of reports that can assist in marketing, normal transactions, and evaluating which types of activities are most productive. These types of reports include:

1. Records of responses by category of individual, geographic region, date, etc.

2. Records concerning the types of programs that elicited the greatest responses. 
3. Responses by geographic region.

4. Success of follow-up programs by geographic region.

5. Lists of the entire file broken down into various categories or sub-files by characteristic as required.

6. Labels generated in accordance with specified categories.

\section{Proposed Coverage}

Andrews University $\mathrm{plans}$ to provide a 24-hour Sunday answering service utilizing service representatives. From Monday through Friday the telephones will be answered from 8-5 by office personnel, and after 5 by call answering devices. If other agencies utilize the answering system requiring service representatives to be on duty during other hours of the day, these representatives will al so answer any It Is Written cails.

Andrews University $p l a n s$ to install 14 incoming lines and 1 outgoing line. These $\mathrm{pl}$ ans are based on an estimated 200,000 responses per year, or 3,846 per Sunday over an 18hour broadcasting period. A pilot project for Faith For Today has shown that the average call can be serviced in one and a half minutes. Using this average, 14 operators could service 560 calls per hour. During the first month the number of busy signals would be monitored to determine how adequately the calls are being served. Based on this data, necessary adjustments would be made.

\section{Computer Processing}

Computer processing of data files created from the mail and phone responses will include generations of:

1. Computer tapes with information needed for any processing done in Boston.

2. Labels, sorted by product and zip code to be used to mail books or other free materials promoted during the telecast. Normally this will be in the mail within 36 hours after the request has been received. Thus, if a request is received Sunday morning, the material requested will be at the post office by Monday evening.

3. Back-up tapes of master files as needed.

4. Special products will be generated upon request. 
PHASE II

Mailing and Shipping Services

The free booklets will be packaged with a card which has the postal permit and a personal message from Elder Vandeman on the back. This card will be placed over the booklet and the materials shrink-wrapped. It may al so be desirable to have a back card with attractive promotional material. The advantage of shrink-wrapping is that the promotional material can be viewed through the cellophane, the weight is reduced, and the over-all costs may be less. By using these procedures, combined with reduced labor cost at Andrews University, it appears possible to send materials first class within 36-48 hours after the request for the materials has been received and at a better rate.

Other materials which will be mailed include promotional mailings. The cost and procedures for these mailings will be worked out with It Is Written, based upon the nature of each special request. It is possible to produce these letters with any degree of quality, depending upon what is desired. Samples of letters produced by various procedures are included.

In addition to the processing described in Phase I, this phase will include the printing of $4 \times 6$ cards for quality interests. These cards will be sent first class to the individual with a typed message and personal note from the service representative. The note will be used to maintain relationships through expressing appreciation for the call and informing the individual that the book has been mailed.

\section{PHASE III}

Includes all of Phases I and II, plus donor letters and receipting, reports and microfiche. The individual steps included in this phase are detailed on pages 3,4 of the flow chart and include numbers 29-41.

\section{Summary of Services}

The previous sections have given an overview of the types of services that are available through Andrews University. While these services are not unique, the manner in which they are provided is, for the following reasons:

1. The type of persons providing contacts are Seventh-day Adventists who will be future workers or wives of workers. 
2. It will use much of the Church's money twice. First to provide the desired services, and second to support the education of future Seventh-day Adventist workers.

3. There will be training programs to help individuals respond to interests in a way that will be most effective, identify special types of interest, and assess the quality of interest.

4. The coordination of these activities in a single location can greatly reduce the total time between when a request is received and the information is provided to the 1 istener.

Summary of Andrews University Computing Center

Personnel - AUCC now has a staff of 25 students and 21 fulltime workers as shown below:

\begin{tabular}{|c|c|c|}
\hline & Staff & Student \\
\hline $\begin{array}{l}\text { Programmer/Analysts } \\
\text { Operations } \\
\text { Data Entry } \\
\text { Tech Support } \\
\text { Academic Services } \\
\text { Microfiche } \\
\text { Administrative }\end{array}$ & $\begin{array}{l}7 \\
4 \\
2 \\
4 \\
2 \\
0 \\
2 \\
2\end{array}$ & $\begin{array}{l}7 \\
3 \\
1 \\
1 \\
3 \\
8 \\
2 \\
\end{array}$ \\
\hline Totals & 21 & 25 \\
\hline
\end{tabular}

When school is in full session, our staff expands to 75 members. The director of Andrews University Computing Center reports directly to the Assistant to the President, which allows AUCC to function as a full service department equaliy divided among alt users.

Software. AUCC has an estimated investment of $\$ 5,000,000$ in software. Our system provides a totally on-line registration, grades and transcript service. In addition to our own University registration system, we al so have a different on-line system for registration for Lake Michigan College, located in Benton Harbor, Michigan, about 15 miles from our campus. AUCC has been servicing Lake Michigan College for the last five years. A dedicated staff, always open to new ideas, and a consistent f1 ow of students through AUCC has produced and made functional our latest systems.

Equipment. At the present time we have two Xerox computers, a Sigma 6 and a Sigma 7 . Both computers have 128K words of memory and run $C P-V$ operating systems. We currently support nearly 100 on-line terminals and yet, system response time is 
typically well below 0.5 seconds. Both systems have the capability, within a reasonable time, to back each other up. Printing is done on two IBM 1403-N1 iine printers with full upper and lower case print trains. We foresee no problems in adding an additional 20 terminals for It Is Written.

AUCC staff maintain all of the present computer equipment, including the IBM printers. This has given us extremely high rel iability at very low cost. We currently have over $\$ 40,000$ worth of spare parts, and if more are needed there are many places to obtain them quickly. The AUCC computer system is valued at $\$ 1,500,000$. IBM recently quoted us a figure of $\$ 2,000,000$ to replace our present system, p1 us $\$ 2,000$ per month for software charges. The report further stated that the proposed system would only be able to provide $98 \%$ of our present services.

Since we are not dependent upon vendor support, we are free to choose the most cost-effective add-on equipment with no fear of finger-pointing between multiple vendors, or we can buy used equipment for a small fraction of the cost it would be if purchased through the usual suppliers. 


\section{ADVANTAGES}

The advantage to the Seventh-day Adventist Church and related organizations include:

1. Cost Effectiveness. The services described in this proposal involve a broader range of activities at a lower cost per activity than it is Written is presently paying or can obtain in the industry for equal services.

2. El iminate telephone costs that are incurred in a volunteer system. Elder Vandeman told of a CPA who pays for six lines only to find that on some - occasions there are no operators on duty, and calls are not being serviced. This expense for telephone lines, lost interests, and dampened morale would be el iminated through the services described in this proposal.

3. Reduced management time. Currently It Is Written must engage in a constant effort to maintain a volunteer network of operators. This is complicated by the fact that It Is Written will soon be broadcast through cable and satellite systems. This will make it impossible to have local numbers due to the lack of churches in some cities, or to provide operators during a variety of unknown broadcast times. The services described in this proposal would relieve It Is Written of some of the management costs involved in operating a volunteer system.

4. Reduced turnaround time between the request for a book, visit, etc., from six to eight weeks to one week to two weeks. The exact turnaround time would depend on the type of service and the type of procedures which are agreed upon. Once operational, it appears that it would be possible to ship most materials or mail interest lists to pastors within 48 hours of the initial call.

5. There will be trained Seventh-day Adventists answering phone requests. These will be individuals who have been carefully selected because of their qualification and interest in this soul-winning ministry, rather than untrained personnel from a non-church service organization.

6. It will be possible to gather nation-wide lists and provide these by area of interest, geographic location, repeat requests, etc. These can be made available to pastors and evangelists as they 
organize soul-winning endeavors in various locations.

7. The quality of interest will be estimated by the trained service representatives who answer the phone. These individuals will be trained how to initiate requests for Bible studies or other services such as 5-day plans, nutrition workshops, etc.

8. The service representatives will be trained to help sense special needs of listeners, and to initiate discussions that may help pastors or 1 aymen who follow-up be more responsive in ways that can help foster ul timate decisions.

9. Individuals participating as phone service representatives will become oriented toward following up leads of interested individuals when they become active 1 aymen or workers. This can contribute to increasing long-term effectiveness of media related evangelism.

10. A variety of activities being consolidated in a single location will make it simpler to coordinate these activities and make the activities more timely and cost-effective.

11. The majority of funds used to purchase these services through Andrews University will go into paying for student or student spouse 1 abor, which will assist future ministers, their wives, and other future workers in completing their college or seminary education. Thus, the funds used will serve a double purpose for the Church.

Andrews University has many unique capabilities that make it possible to provide these services in a way that will be most beneficial to the Church. These capabilities include:

1. A Targe pool of student and student spouse workers who are highly qualified. Many of these individuals have carried important responsibilities before continuing their graduate or seminary education at Andrews University.

2. The generar wages paid to students and student spouses are considerably less than would have to be paid el sewhere. This in part is because the church subsidizes the education of many of these individuals in other ways through sponsorship, and assisting the University in providing housing at reduced costs. When both the cost of wages and fringe benefits is considered, personnel costs may 
be as 1 ittle as $50-75 \%$ of what would have to be paid el sewhere to a ful1-time staff member.

3. Students and student spouses are willing to work unusual part-time schedules. Thus, the peaks and valleys related to the nature of this type of work can be efficientiy accomodated. It will be easily possible to have thirty or more people work answering phones and processing information on Sunday when the peak requests will come, and significantly reduce this number on other days while still providing half-time work to these employees.

4. Andrews University has a highly qual ified

- technical staff of 23 ful1-time computer personnel, and a Computer Science program with over 70 majors. This provides a resource of technical help that cannot be dupl icated el sewhere within the church. The computing center currentiy employs many students and has experience in providing supervision for technical activities. It provides all of the maintenance for its hardware, software, and has developed hardware which it uses in the computing facility.

5. Having this type of soul-winning activity at Andrews University $\mathrm{places}$ it at a location where it can educate the greatest number of future North American ministers concerning how they can use information provided through the media programs, and allow them and their wives to become directiy involved in a way that will make them more: responsive to this type of ministry when they become full-time workers.

The Administration of Andrews University is willing to make every reasonable effort to cooperatively work with it is Written to provide the most effective procedures possible in terms of soul-winning results, contributions to the television ministry, and cost benefits. This commitment includes some support for faculty members who wish to do research related to how such services can he improved, and a willingness to minimize the marg in of profit for such an operation below what would be expected commercially.

The University is committed to this particular endeavor because of its soul-winning implications, the large amount of meaningful work it provides students and their spouses, and because it has the majority of resources in place to provide the services. Andrews University is confident in combining its efforts with It Is Written it will be possible to provide the services in a very effective manner which will be to the glory of God. 
APPENDIX C

\section{SATISFACTION WITH RELATED SERVICES \\ AT ADVENTIST INFORMATIION MINISTRY}

1. An Introduction to Table 8.

2. Table 8: Satisfaction with AIM's Services: Agency, Chaplains, Committee, Pastors, and Staff Response.

3. Analysis and Evaluation of Table 8 Findings.

4. Unanswered Questions and the Lowest Scores in Table 8 . 


\section{Satisfaction with Related Services At Adventist Information Ministry: An Introduction to Table 8}

In the closing section of the interview survey, six questions were packaged together which inquired about satisfaction of services performed by Adventist Information Ministry. Questions were answered by five different groups, including: six persons with agencies AIM has served, twentyfive AIM chaplains, eight executive steering committee members, fourteen pastors, and four AIM staff members. The first three of the six questions, questions $47,48 \mathrm{~A}$ and $48 \mathrm{~B}$, primarily reflected on the work of AIM phone operators and their shift leaders; whereas the latter three questions, $48 \mathrm{C}, 48 \mathrm{D}$ and 49 , focused on functions attributed mostly to the chaplains at AIM. The following five options could be chosen as answers for the fifty-seven respondents: 1-not at all satisfied; 2 -a little bit satisfied; 3 -somewhat satisfied; 4-considerably satisfied; and 5-very satisfied. Results were tabulated and have been set forth in Table 8 on the following page of the dissertation, accompanied by the answer key for the six questions located at the bottom of the page. 
TABLE 8

SATISFACTION WITH AIM'S SERVICES:

AGENCY, CHAPLAINS, COMMITTEE, PASTORS, AND STAFF RESPONSE

\begin{tabular}{||l|c|c|c|c|c||c||}
\hline $\begin{array}{l}\text { Number of respondents -- } \\
\text { Satisfaction } \\
(6)\end{array}$ & $\begin{array}{c}\text { Chaplains } \\
\text { Satisfaction } \\
(25)\end{array}$ & $\begin{array}{c}\text { Committee } \\
\text { Satisfaction } \\
(8)\end{array}$ & $\begin{array}{c}\text { Pastors } \\
\text { Satisfaction } \\
(14)\end{array}$ & $\begin{array}{c}\text { Staff } \\
\text { Satisfaction } \\
(4)\end{array}$ & $\begin{array}{c}\text { Average } \\
\text { score per } \\
\text { question: }\end{array}$ \\
\hline $\begin{array}{l}\text { Q.47--AIM serving as } \\
\text { a bridge between } \\
\text { people seeking } \\
\text { guidance and those } \\
\text { who can help them? }\end{array}$ & 3.66 & 3.64 & 4.50 & 3.88 & 3.50 & $(3.84)$ \\
\hline $\begin{array}{l}\text { Q.48a--AIM's } \\
\text { processing phone and } \\
\text { coupon requests? }\end{array}$ & 4.60 & 3.79 & 4.20 & 4.50 & 4.00 & $(4.21)$ \\
\hline $\begin{array}{l}\text { Q.48b--AIM's } \\
\text { qualifying the seeker's } \\
\text { level of interest? }\end{array}$ & 4.25 & 3.32 & 3.50 & 3.50 & 3.33 & $(3.58)$ \\
\hline $\begin{array}{l}\text { Q.48c--AIM's } \\
\text { referring interests as } \\
\text { quickly as possible? }\end{array}$ & 4.00 & 3.44 & 3.80 & 4.00 & 3.50 & $(3.75)$ \\
\hline $\begin{array}{l}\text { Q.48d--AIM's } \\
\text { periodically } \\
\text { monitoring interests } \\
\text { through follow-up } \\
\text { calls? }\end{array}$ & $\mathrm{X}$ & 3.36 & 3.75 & 4.00 & 2.50 & $(3.40)$ \\
\hline $\begin{array}{l}\text { Q.49--AIM's } \\
\text { contribution to } \\
\text { winning souls for } \\
\text { Christ? }\end{array}$ & 4.66 & 3.96 & 4.14 & 4.08 & 3.25 & $(4.02)$ \\
\hline \hline $\begin{array}{l}\text { Average score } \\
\text { per group: }\end{array}$ & $(4.23)$ & $(3.58)$ & $(3.98)$ & $(3.99)$ & $(3.35)$ \\
\hline
\end{tabular}

TABLE 8 ANSWER KEY

1-Not at all satisfied

2-A little bit satisfied

3-Somewhat satisfied

4-Considerably satisfied

5 -Very satisfied

$\mathrm{X}$-Invalid... (only one reply) 


\section{Analysis and Evaluation of Table 8 Findings}

The five groups of interviewees reported a fairly high level of satisfaction with AIM's services in general. An overall scoring of 3.8 for AIM was calculated from the average scores for each question, which indicated that the fifty-seven interviewed individuals collectively felt quite close to "considerable satisfied" with Adventist Information Ministry's performance at large.

A closer look at the six areas of service under scrutiny in these questions about AIM displayed the highest level of satisfaction occurring with processing phone and coupon requests, as revealed in the far right column in Table 8. According to the total interview response generated by question $48 \mathrm{a}$, this routine practice performed by AIM employees received an overall rating of 4.21 , with every group granting it an averaged score of 4 or more except for the chaplain group who signaled a slightly lower level of satisfaction with their 3.79 score for this service. AlM's contribution to winning souls for Christ weighed in next heaviest on the satisfaction scale with an rating of 4.02 , despite receiving three votes of "a little bit satisfied" from two chaplains and one AIM staff member. In the middle of the pack was question 47 directed toward AIM building bridges between people seeking guidance and those who can help them, which received $3^{\text {rd }}$ place in satisfaction among the six contenders with a 3.84 rating. 
This was followed by question $48 \mathrm{c}$ dealing with chaplain's referrals which picked up a score of 3.75 from the people surveyed. At the lower end of satisfaction came the rating of 3.58 for phone operator's qualifying a caller's level of interest in question $48 \mathrm{~b}$. Last place in the satisfaction scores went to chaplains with a 3.4 score from the five groups for how well AIM chaplains periodically monitored interests through follow-up calls.

From a group to group perspective which can be viewed on the bottom line of Table 8 , the AIM staff were the least willing to hand out high satisfaction scores among the five groups surveyed. These staff members averaged a 3.35 overall rating of the Adventist Information Ministry they superintend. Next up were the chaplains, who said they were half way between somewhat satisfied and considerable satisfied according to their group score of 3.58 for ranking AIM's services. Closely aligned in the middle of satisfaction levels among the five groups were the executive steering committee group who reported an overall satisfaction level of 3.98 with AIM and the surveyed pastors with their 3.99 average scoring of AIM's services, signaling that both groups were "considerably satisfied" with these aspects of AIM's work. The six agency persons who answered two or more of the six questions displayed the highest degree of generalized satisfaction with Adventist 
Information Ministry as revealed by their 4.23 overall score of related services at AIM.

The results of the group to group scoring appear to reveal a healthy outlook from the standpoint that the people closest to AIM were the most conservative in expressing their satisfaction levels. It would seemingly be in AIM's favor that the insiders--the staff and chaplains who work at AIM--were a little harder on themselves then the people looking in on AIM from the outside. This group by group view further suggests that the closer a group was to the daily operations at AIM, the more knowledgeable they were of AIM's flaws and thus the greater reluctance they had to bestow higher marks upon AIM's related services.

Looking at the group to group comparison from another perspective suggests an apparent challenge lies ahead and must be addressed by AIM. A $17.6 \%$ difference of opinion was calculated between the five group's lowest and highest levels of satisfaction with AIM as discovered between the staff and agency response to the six questions. While this comparison reveals a relatively small difference of opinion, it could be telling the folks who are closest to the work at AIM that they have some necessary work to do to improve AIM's services. If those involved with the daily operations at AIM are to prevent their exterior image with its higher ratings from eroding and resembling the lower level of satisfaction they themselves placed upon AIM, they 
must respond by confronting and working to improve upon their own areas of lower satisfaction at Adventist Information Ministry.

\section{Unanswered Questions and the Lowest Scores in Table 8}

of the fifty-seven individuals counted as answering questions among the five groups referred to in Table 8 , twenty-one of these persons chose to not answer one or more of the six questions highlighted in this table a total of fifty-one times. From a percentage view point, $36.8 \%$ of these interviewees did not answer one of the six questions 14.9\% of the time they were asked. The agency interviewees were the group with the greatest degree of unanswered questions, with five of the six persons ( $83.3 \%$ ) choosing not to answer one or more of the six questions a total of fourteen times. $57.1 \%$ within the pastor group did not answer questions eighteen different times, and $50.0 \%$ of the committee group withheld their answers on fifteen questions. Three AIM staff members refrained from giving their reply to a total of three of these questions. The chaplain group answered this set of six questions the most consistently with one of the twenty-five chaplains excusing themselves from one question.

In pondering why so many interviewees chose not to respond so frequently to one or more of the six questions, the author can only surmise the reluctance was simply due to 
lack of familiarity with the subject area being asked about. If the group of chaplains near perfect record and the AIM staff members nearly complete response to these six questions were much different, a deeper look into what transpired with the other groups of people with so many. unanswered questions would have been considered for those who had not worked with AIM daily.

Final comments regarding two other hidden findings associated with Table 8 should be mentioned. The lowest averaged score for an AIM service came from the AIM staff group when asked in question 48D about their satisfaction associated with the follow-up of AIM interests, a fundamental responsibility of the AIM chaplain. Two of the four AIM staff chose to not answer this question because it was outside of their own work area at AIM. The author suspects that had one or two of these staff responded, this score would have risen slightly to average out in the lower 3 's range where the next level of lower scores was hovering. Consequently, it did not seem appropriate to single out this lowest of the low scores for critique, given that the AIM staff's reply to question $48 \mathrm{~d}$ was based on only two people's opinion.

The other low score needing comment is directed to the same $48 \mathrm{~d}$ question under the Agency column because only one person for the agency group gave the author a reply. This one agency individual cited a high five for their 
satisfaction with "periodically monitoring interests through follow-up calls." With just one person responding the author felt this was the place to draw the line for valid response, thus rendering the agency group's reply to this question as invalid which is symbolized by the $\mathrm{X}$ in the box to the immediate right of question $48 \mathrm{~d}$ under the agency column. 
APPENDIX D

INTERVIEW INSTRUMENT 
INTERVIEW INFORTMAIION

Name: Date associated with A|M:

fosition(s) associated with AIM:

\section{Call information}

Date: Time:

Code: Phone:

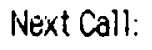

Code: Phone:

Note:

Call code

$$
\begin{aligned}
& \text { QS }=\text { Busy Signal } \\
& M M=\text { Message--Machine } \\
& M P=\text { Message--Person }
\end{aligned}
$$

\begin{tabular}{|c|c|c|c|c|c|}
\hline People-72 & Section 1 & Section 11 & Section III & Section IV & Section $y$ \\
\hline Founders-4 & All & All & $20,22-25,28$ & $41-43$ & $47-49,52-53$ \\
\hline Steering-10 & All but 8 & All & (same +16$)$ & All & $44-49.52-53$ \\
\hline Staff-4 & All & All & (same +16$)$ & All & (same as above) \\
\hline Chaplains- 30 & Skid & Sk10 but 12 & All & All & (same as above) \\
\hline Agencies -6 & Skip & Skip but 12 & Skip & Skip & $47-53$ \\
\hline Fastors -12 & Sklo & $5 \mathrm{k} 10$ but 12 & $5 k 10$ & $29-31$ & (same as above) \\
\hline
\end{tabular}

$$
\begin{aligned}
& \text { WA }=\text { No Answer } \\
& D S=\text { Out of Service } \\
& S A=\text { Scheduled Appointment }
\end{aligned}
$$

\section{Questions}




\section{Phone interview Introduction (Time:}

Hello, (intarviewae's name), this is Elder Greg Harper, Senior Chaplain at Adventist Information Miristry and a doctoral student here at Andrews University. I understand that you have bien assuclated with All1 as is that correct?

I' $m$ in the firial phase of research for my ductoral project. My topic revolves around Adventist Information Ministry, and the rule uf the Ally Chaplain. I've had a number of conversations and megtings relating to my disar tation with AlM Directur Or. Rubert Moon, and arn grateful that Bob hes been very helpful arid supportive of this project.

In order to ütatain a repre esentative sampling of opiriours, I'm conducting phone interviews with the AIM Founders, Steering Cammittee Members, Staff, Chaplains, and a handfull of Agencies as well as Pastors thát AlM hàs served.

I'm calling you (Interviewee's name), with an Invitation to participate with me in a phone Intervlew that would take about 30 minutes, depending upon the length of your answers. I'm woidaring if you would be interested in participating? is this something that could fit into your present schedule today, or would it be better to make an appointment for later this wook?

\section{Agreement to being Quoted and Recorded}

I would like to obtain your permission on two ltems: One--To quote any oi your answers in my disertation when it would be appropriate to do so. If I do this. I will not refer to you by name but as one of the

Two--In order to insure accuracy for quoting, I will be recording our conversation. Are both of these agreeable to you? (Prayer for brevity and clarity)

\section{Introduction Questions (Iime:}

A. How tamiliar are you with the work oi Adventist Information Ministry?

$$
\begin{array}{ll}
\square & \text { Not at all familiar } \\
\square & \text { Not too fomiliar } \\
\square & \text { Somewhat familiar } \\
\text { D } & \text { Ouite familiar } \\
\square & \text { Very familiar }
\end{array}
$$

B. What has been your level of involvement with AIM?

No involvement Very limited invoivement Moderate involvement Considerable involvement Extensive involvement 


\section{section l: AlM's Historical Foundations}

1. Who first concelved of the origingl, inttial ides for AlM?

2. In the early developmental stanes of AIM, what were some of the key issues and concerns beino ralsod?

3. How did the name--Adventist Information Ministry--come about?

4. Who should be identffied as the AIM founder(s)--one indlvidual, or a small group of people?

5 Was there an nfficial booy that mandated or authorized AlM's existence? When and where was this action recorded?

6. What do you see as being the essential components of AlM's operational structure?

7. How did the role of the AIM chaplain develop? Who set their initial gagls and objectives?

8. When and where did AIM officially open Its doors for business? Who were the on-site staff that began managing AIM, and what work was being done?

9. Is the AlM ministry unique? What is its closest counterpart within the SOA Church? 


\section{Saction ill: All's Theolovical and Missiolouical Foundations}

10. How would you deser ite God's involverient in the AlM story?

11. Did any significant expertences or events happen that portrayed God's role in the AIM story?

12. How would you descr tbe the mission of AlM?

13. In formulating AlM's mission, what Bible passoges would the founder(s) hove had in mind?

14. What comiments fromi Ellen White would have impacted the AlM founder(s) in establishing the mission of AIM?

15. How does the AiM acronym project a sense of mission for Adventist Information Ministry? 


\section{Sectuon 111: The AlM choolains}

16. How would you evaluate the job training that AIM Chaplains recelve?

17. To what extent would a comprehensive, current AlM chaplains manual be useiul as a sourcebook for training new AiM chaplains? And as a reierence ior more seasaned AIM chap lains?

18. How are the chioplains at Adventist Information Ministry held accountable for their work?

19. Did you or the chaplain's department ever undergo any evaluation while working at AIM?

20. Is it within the scope of the AIM Chaplain's ministry to do counseling? Explain.

21. What would you soy were the strengths and weaknesses of the weekly chaplain's meeting?

22. Describe your philosophy for how prayer requests called in to AlM's $800^{*}$ should be handled. 
23. How important are the chaplain's "success stories" in relationship to the overall mission of AIM?

24. Rank the following iunctions periormed by AlM chaplains in order of their importance, with one being most important, down through six as least important.

- Meetings (for coordination, inspiration, \& development of chaplains)

- Administrative (data entry, scheduling, letters, reporting baptisms)

- Couniseling (ronging from orisis calls to answer irig Bible questions)

- Referral (of requests for Bible studies \& visits to the local church)

- Intercession (for previousiv called in \& on the spot prover requests)

_ Follow-Up (of reierral interests to periodically monitor progress)

25. Why did you rank these functions for AlM chaplains in the order that you did?

26. Now rank the same functions periormed by AIM chaplains in order of time actually spent with each function, with one being most time spent, down through sIx as least time spent.

- Meetings (for coordination, inspiration, \& development of chaplains)

- Administrative (data entry, scheduling, letters, reporting baptisms)

- Counseling (ranging from crisis calls to answering Bible questions)

- Referral (of requests for Bible studies \& visits to the local church)

- Intercession (for previously called in \& un the spot prayer requests)

— Follow-Up cof referral interests to periodically monitor progress

27. What time management adjustments did you make in order to deal with these multiple tasks?

28. What has been your greatest contribution to AIM while serving this organization? 


\section{Saction lv: AlM Chaplain and Leadershio Rolos}

29. What is your understanding of the role of the AlM Chaplain?

30. Are there areas that you see where this role can oe improved?

31. What has beer the Chaplain's most significant contr ibution to AlM?

32. What is your understanding of the role of the AlM senior Chaplatin?

33. Are there areas that you see where this role can be improved?

34. What has bean the Senior's Chaplain's most significant contribution to AlM?

35. What is your understanding of the role of the AlM Follow-Up Coordinator?

36. Are there areas that you see where this role can be improved?

37. What has been the Follow-Up Coordinator's most significant contribution to AIM? 
zo. What to vour understanding of the role of the AlA birector?

39. Are there areas that you sea where thits role can be improved?

40. What has beeri the Director's most significant contribution to AIM?

41. What is your understanding of the role of the AlM Steer ing Committee? What is the basis for membership on this committee?

42. Are there areas that you seo where this role can be improved?

43. What has been the Steer ing Committeg's most slgnificant contribution to Alli?

\section{Section V. Evaluation and Recommendations}

44. Does the composition of the AIM Steering Committee provide sufficient representativeness for the constituents and agencies served by AIM? Explain.

45. Is the Steer ing Committee adequately addressing the concerns of AIM Staff members? Explain.

46. Have the actions of the Alli steering Committee been Implemented in a satisfactory and timely manner? Explain. 
47. How satisfied are you with how AlM has followed through with providing a bridge between people who are seeking guidance, and those who can help them?---->Any other comments?

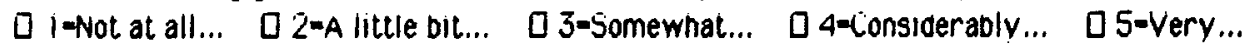

48. How soilisiliay are vou wtth the service that AlM has performed according to the following functions?---- Any additional comments?

A. Processing phone and coupon requests.

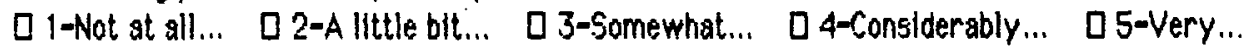

B. Qualifying the seeker's level of interest.

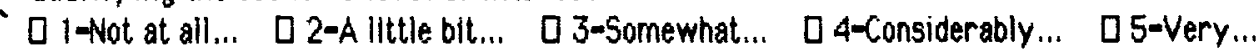

C. Referring these interests as quickly as possible to the local church or other approprlate agency.

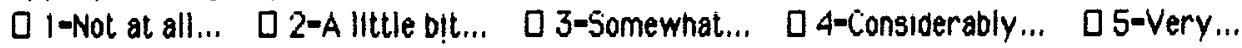

D. Periadically manitering the progress of an interest referred to the local church.

$\square$ 1-Nol at all... $\square$ 2-A little bit... $\square$ 3-Somewhat... $\square$ 4-Considerably... $\square 5-$ Very...

49. How sotisfied are you with AlM's contr fbution to winning souls for Jesus Christ?-----? Explain whiv.

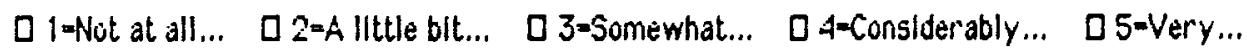

50. Has AIM Denefitted your personal ministry, or your organization's ministry, in any woy?

51. Has AIM hindered your ministry in any way, or proyided unsatisfactory service to your organization?

52. What do you percelye are the biggest barriers to a more efficient and effective Adventist Information Ministry?

53. Are there any untapped opportunities you might suggest that AIM or the AIM Chaplain's should explore?

(Time: 
APPENDIX E

PHONE LOG

1. Phone Log: Agencies

2. Phone Log: Chaplains

3. Phone Log: Committee/Founders

4. Phone Log: Pastors

5. Phone Log: Staff 
Person Number:

1 .

2 .

3.

4 .

5 .

6.

7 .

8.

9.

10.
Date \& Time: Result:

4-27 1:53pm

4-28 5:00pm

Call 4-28 at 5:00pm

Conducted $15 \mathrm{~min}$ interview

4-27 2:37pm

$2: 50 \mathrm{pm}$

Call back in 10 minutes

Conducted $10 \mathrm{~min}$ interview

$5-3$

$1: 30 \mathrm{pm}$

8:00am

$8: 13$ am

Call 5-4 at 8:00am

Busy

Conducted 12 min interview

Call 4-28 at 9:30am

Conducted $10 \mathrm{~min}$ interview

$\begin{array}{ll}4: 32 & 2: 32 \mathrm{pm} \\ 4-28 & 9: 35 \mathrm{~m}\end{array}$

Call 4-28 at 2:30pm

Call 4-29 in am

Conducted $10 \mathrm{~min}$ interview

4-29 9:53am

Call 4-28 at 11:00 am

Busy signal

Left message

Unavailable this week

5-3 1:27pm

5-3 $1: 40 \mathrm{pm}$

5-4 5:20am

Call 5-4 at 5:15am

Call another number

$5: 24$ am

Conducted $12 \mathrm{~min}$ interview

Call after 7:30am

Call at 11:30am

Busy

$11: 31 \mathrm{am}$

$11: 37 \mathrm{am}$

Conducted $43 \mathrm{~min}$ interview

$$
\begin{array}{rr}
4-27 \quad 2: 28 p m \\
4: 53 p m
\end{array}
$$

Call at $4: 40 \mathrm{pm}$

In a meeting

Call at 5:00pm

Conducted $15 \mathrm{~min}$ interview 
PHONE LOG: CHAPLAINS

Person Number:

11 .

12.

13.

14 .

15 .

16 .

17.

18

19.

\section{Date \& Time: Result:}

\section{5-1 3:25pm Busy}

$3: 35 \mathrm{pm}$ Conducted $50 \mathrm{~min}$ interview

$$
\begin{array}{ll}
4-25 & 4: 24 \mathrm{pm} \\
5-1 & 12: 54 \mathrm{pm} \\
& 8: 08 \mathrm{pm} \\
5-3 & 7: 00 \mathrm{am} \\
& 7: 07 \mathrm{am}
\end{array}
$$
4-25 4:31pm
$10: 30 \mathrm{pm}$
4-26 12:06pm

$4-25$

$4: 34 \mathrm{pm}$

$5: 22 \mathrm{pm}$

$4-25 \quad 4: 36 \mathrm{pm}$
$4: 41 \mathrm{pm}$
$4: 42 \mathrm{pm}$

$5-1$

$1: 20 \mathrm{pm}$

$5-1$

$1: 13 \mathrm{pm}$

$8: 22 \mathrm{pm}$

$5-2 \quad 7: 58 \mathrm{pm}$

$4-25$

$5-1$

$5-2$

$5-3$

$5: 14 \mathrm{pm}$

$1: 16 \mathrm{pm}$

$7: 53 \mathrm{pm}$

$9: 35 \mathrm{am}$

4-25 5:17pm

5-1 $1: 18 \mathrm{pm}$

5-2 7:56pm

5-4 $11: 26$ am

$12: 25 \mathrm{pm}$

$12: 27 \mathrm{pm}$

$1: 05 \mathrm{pm}$

$1: 12 \mathrm{pm}$
No answer

Wife said call back

Call 5-3 at 7:00am

Temporarily unavailable

conducted $40 \mathrm{~min}$ interview

Left message (home phone)

She called \& left message

Conducted $19 \mathrm{~min}$ interview

Left message with mother

Conducted $40 \mathrm{~min}$ interview

Busy signal

No answer

Conducted $26 \mathrm{~min}$ interview

Out of country with ADRA

No answer

No answer

Unavailable (Crusade)

Busy signal

Left message (home phone)

Call 5-3 at 9:30am

Conducted $38 \mathrm{~min}$ interview

Left message (home phone)

Left message (home phone)

Left message (home phone)

He called \& left message

Left message (church sec)

Left message (home phone)

He returned call

Conducted $34 \mathrm{~min}$ interview 
Person Number:

20.

21 .

22 .

23.

24 .

25.

26 .

27.
Date \& Time: Result:

$\begin{array}{ll}4-27 & \text { am } \\ & \text { am } \\ & \text { am } \\ 5-3 & 11: 53 \mathrm{am} \\ 5-4 & 9: 40 \mathrm{am} \\ & 9: 45 \mathrm{am}\end{array}$

Called NY Conf for phone \# Called Greater NY Conf " Called Alleg. E. Conf " Left message (home phone) son suggested call church Left message (church sec)

4-25 5:20pm

5-1 1:28pm

5-2 8:00pm

5-24 eve.

5-27 7:55am

$5-27 \quad 5: 45 \mathrm{pm}$

Left message (home phone) Left message (home phone) Left message (home phone) Received his return call No answer (home phone) No answer (home phone)

4-25 5:22pm

No answer (home phone)

No answer (home phone)

5-1 1:31pm

No answer (home phone)

5-2 $8: 03 \mathrm{pm}$

No answer (home phone)

4-25 $7: 17 \mathrm{pm}$

4-26 12:03pm

Call 4-26 at 12:00p

Conducted $67 \mathrm{~min}$ interview

4-27 am

am

am

5-3 12:00pm

5-4 $9: 48 \mathrm{am}$

$\begin{array}{ll}4-25 & 7: 22 \mathrm{pm} \\ 5-2 & 8: 15 \mathrm{pm} \\ 5-3 & 2: 38 \mathrm{pm} \\ & 5: 33 \mathrm{pm}\end{array}$

Left message (home phone) Left message (home phone) He returned call Conducted $42 \mathrm{~min}$ interview

Called NY Conf for phone \# Called Greater NY Conf Called Alleg. E. Conf: Left message (home phone) wife said diffic. to reach

4-25 7:28am

$7: 29$ am

$7: 30$ am

$9: 33 \mathrm{am}$

Left message (ph. no. A) Busy signal (ph. no. B) Left message (ph. no. C) He returned called--

Conducted $39 \mathrm{~min}$ interview

$\begin{array}{ll}4-25 & 10: 45 \mathrm{am} \\ & 7: 35 \mathrm{pm} \\ & 10: 39 \mathrm{pm} \\ 4-26 & 10: 50 \mathrm{am}\end{array}$

Busy signal

Left message (home-wife)

He returned call

Conducted $63 \mathrm{~min}$ interview 
Person Number:

28 .

29.

30.

31.

32 .

33.

34 .

35 .

36.
Date \& Time: Result:

4-25 7:40pm

Left message (home phone)

4-29 $12: 26 \mathrm{pm}$

Conducted $59 \mathrm{~min}$ interview

$$
\begin{array}{ll}
4-25 & \text { mid aft } \\
4-28 & \text { mid aft } \\
5-2 & 3: 30 \mathrm{pm} \\
5-3 & 3: 45 \mathrm{pm} \\
& 4: 35 \mathrm{pm}
\end{array}
$$

Busy
Busy
Busy
Busy
Conducted 46 min interview

$\begin{array}{ll}4-25 & 7: 45 \mathrm{pm} \\ 5-1 & 1: 35 \mathrm{pm} \\ & 6: 30 \mathrm{pm} \\ 5-2 & 7: 47 \mathrm{pm}\end{array}$

Left message (home phone)

Call between 5:00-7:30pm

Left message (home phone)

Not available at home

$$
\begin{array}{ll}
4-25 & 7: 47 \mathrm{pm} \\
& 7: 58 \mathrm{pm} \\
4-27 & 8: 59 \mathrm{pm} \\
5-1 & 1: 39 \mathrm{pm}
\end{array}
$$

Call back in 10-15 min.

Call 4-26 11:30am-3:30pm

Call 4-29 before 3:00pm

Conducted $47 \mathrm{~min}$ interview

\section{4-25 7:50pm}

4-27 unknown

Left message (home phone)

He called \& left message

$\begin{array}{ll} & 8: 55 \mathrm{pm} \\ 5-1 & 2: 30 \mathrm{pm}\end{array}$

Left message (home phone)

Left message (home phone)

Left message (home phone)

5-2 12:30 am

He called \& left message

9:04 am

Left message (home phone)

$9: 14$ am

Conducted $79 \mathrm{~min}$ interview

$\begin{array}{ll}5-1 & 2: 38 \mathrm{pm} \\ & 4: 28 \mathrm{pm} \\ & 6: 35 \mathrm{pm} \\ 5-2 & 12: 06 \mathrm{pm}\end{array}$

Left message with son

Left message (home phone)

Call 5-2 at noon

Conducted $44 \mathrm{~min}$ interview

4-26 mid aft

4-28 mid aft

4-29 4:10pm

Busy

Busy

Conducted 36 min interview

$$
\begin{array}{rr}
4-25 \quad 7: 55 \mathrm{pm} \\
8: 06 \mathrm{pm}
\end{array}
$$

Call back in 15 minutes

Conducted $47 \mathrm{~min}$ interview

5-1 2:40pm

Left message with wife

5-3 12:05pm

$5-4 \quad 9: 52 \mathrm{am}$
No answer

No answer 
Person Number: Date \& Time: Result:

37 .

$\begin{array}{lll}\text { 5-1 } & 2: 46 \mathrm{pm} & \text { Left message (home phone) } \\ & 8: 29 \mathrm{pm} & \text { Left message (home phone) } \\ 5-2 & 8: 10 \mathrm{pm} & \text { Left message (home phone) } \\ & 9: 30 \mathrm{pm} & \text { Call returned--Add.unknown }\end{array}$

38.

$4-27 \cdot 10: 00 \mathrm{pm}$

$5-1 \quad 2: 50 \mathrm{pm}$

$\mathrm{Ph}$ no. out of service

5-3 12:08pm

No new listing with oper.

OR Conf: C.R. in transit--

Current address unknown

39.

4-27 am

am

am

Called NY Conf for phone \# Called Greater NY Conf:

Called Alleg. E. Conf:

Current address unknown

40.

$$
\begin{array}{ll}
4-27 & 3: 29 \mathrm{pm} \\
& 9: 01 \mathrm{pm} \\
& 9: 04 \mathrm{pm} \\
4-29 & 11: 30 \mathrm{am} \\
& 1: 45 \mathrm{pm}
\end{array}
$$

41 .

42 .

43.

44.

45.

46.
4-29 5:30pm

$5-1$

$2: 53 \mathrm{pm}$

5-2 $7: 10 \mathrm{pm}$

$4-27 \quad 3: 31 \mathrm{pm}$

4-28 9:20am

4-27 3:10pm

4-29 3:35pm

$5: 27 \mathrm{pm}$

$6: 25 \mathrm{pm}$

5-1 $12: 50 \mathrm{pm}$

$8: 35 \mathrm{pm}$

$9: 22 \mathrm{pm}$

$4-27 \quad 9: 56 \mathrm{pm}$

4-28 4:25pm

5-1 3:02pm
Left message (home phone)

He called and left message

Call 4-29 at 11:30am

Called to reschedule

Conducted $45 \mathrm{~min}$ interview

Conducted $44 \mathrm{~min}$ interview

Call 5-2 around 6:30pm

Conducted $27 \mathrm{~min}$ interview

Call 4-28 btwn 8:30-9:30am Conducted $105 \mathrm{~min}$ interview

Left message (home phone)

He called \& left message

Busy signal

Left message (home phone)

Left message (home phone)

Call in 45 minutes

Conducted $48 \mathrm{~min}$ interview

Left message (home phone) He called \& left message Unavailable until next wk 
Person Number:

47.

48 .
Date \& Time: Result:

$5-1$

$3: 09 \mathrm{pm}$

$5: 46 \mathrm{pm}$

$5: 48 \mathrm{pm}$

$6: 25 \mathrm{pm}$

$4-27$

$9: 25 \mathrm{pm}$

$9: 26 \mathrm{pm}$
Call 5-2 at 5:45pm

Left message (home phone)

Left message (ch. phone)

Conducted $45 \mathrm{~min}$ interview

Call at church

Conducted $25 \mathrm{~min}$ interview 
PHONE LOG: COMMITTEE/FOUNDERS

Person Number:

49 .

50 .

51

52.

53.

54 .

55.

56.

57 .

\section{Date \& Time: Result:}

4-27 9:53am Conducted $17 \mathrm{~min}$ interview

4-27 11:55am

4-28 4:34pm

$4: 36 \mathrm{pm}$

4-29 9:35am

4-27 10:16am

$5-3 \quad 5: 23 \mathrm{pm}$

$5-7 \quad 8: 35 \mathrm{pm}$

$\begin{array}{ll}4-27 & 2: 00 \mathrm{pm} \\ 4: 00 \mathrm{pm}\end{array}$

5-2 9:00am

4-29 3:30pm

5-4 7:33am

4-27 2:12pm

Unavailable (in Indonesia)

Call 5-4 at 7:30am

Conducted $20 \mathrm{~min}$ interview

Call at $4: 00 \mathrm{pm}$

Conducted $45 \mathrm{~min}$ interview Call 5-2 at 9:00am

Conducted $30 \mathrm{~min}$ interview

Call at home 5-3 about 5pm Call 5-7 at 8:30pm

Conducted $85 \mathrm{~min}$ interview

Call on $4-28$ at $4: 30 \mathrm{pm}$

message (his office)

Conducted $10 \mathrm{~min}$ interview 
Person Number:

58.

59.

\section{Date \& Time: Result:}

$\begin{array}{ll}4-27 & 2: 17 \mathrm{pm} \\ 4-29 & 11: 55 \mathrm{am} \\ 5-3 & 12: 44 \mathrm{pm} \\ & 1: 08 \mathrm{pm} \\ 5-5 & 2: 01 \mathrm{pm} \\ 5-6 & 8: 10 \mathrm{am}\end{array}$

No answer

Unavailable until 5-3

Call back after 15 minutes

Call on $5-5$ at 2:00pm EDT

Unavailable until 5-6

He returned call--

Conducted $30 \mathrm{~min}$ interview

4-27 11:25am

4-28 11:45am

$1: 03 \mathrm{pm}$

$1: 05 \mathrm{pm}$

3:00pm
Cal1 4-28 btwn 7:30-4:30

Left message

Left message

Call at 3:00pm

Conducted $45 \mathrm{~min}$ interview 
PHONE LOG: PASTORS

Person Number: Date \& Time: Result:

60.

4-27 8:33pm Phone out of service

61.

$\begin{array}{ll}5-3 & 4: 20 \mathrm{pm} \\ & 9: 30 \mathrm{pm} \\ 5-4 & 9: 37 \mathrm{pm} \\ & 10: 05 \mathrm{pm} \\ 5-5 & 7: 43 \mathrm{am}\end{array}$

Left message (home phone) He called-call 5-4 @9:30pm Won't be home till 10:00pm Won't be home till 2:00am

62.

$4-27 \quad 8: 21 \mathrm{pm}$

$8: 23 \mathrm{pm}$

63.

64 .

65.

66.

67 .
$4-23 \quad 4: 15 \mathrm{pm}$

5-4 10:05am

$5-4$

$4: 08 \mathrm{pm}$

$4: 13 \mathrm{pm}$

$7: 32 \mathrm{pm}$

$7: 34 \mathrm{pm}$

5-2 $8: 20 \mathrm{pm}$

$5-4 \quad 10: 18 \mathrm{am}$

$1: 48 \mathrm{pm}$ mid aft

$3: 44 \mathrm{pm}$

$3: 56 \mathrm{pm}$

$4: 07 \mathrm{pm}$

$4: 15 \mathrm{pm}$

$6: 57 \mathrm{pm}$

5-5 7:47am

4-27 $7: 53 \mathrm{pm}$

$4-29$

$11: 20$ am

$$
\begin{array}{ll}
4-27 & 7: 55 \mathrm{pm} \\
4-29 & 1: 00 \mathrm{pm} \\
& 1: 30 \mathrm{pm} \\
5-2 & 5: 22 \mathrm{pm}
\end{array}
$$

Ph. changed to new number His phone hung up

Call tomorrow morning Conducted 9 min interview

Left message (church ph)

Call btwn 7:00-8:00 pm

Left message (church ph)

conducted $7 \mathrm{~min}$ interview

Left message (home phone)

Call church btwn 1-2pm

Left message (church ph)

He left message--call back

Busy signal

Busy signal

Busy signal

Busy signal

Left message (home phone)

Conducted 9 min interview

Call on 4-29 at 11:00am

Conducted 20 min interview

Call on 4-29 at 1:00pm

No answer

Left message (home phone)

out of town for three days 
Person Number:

68.

69.

70 .

71.

72 .

73 .

74 .

75 .

76 .

\section{Date \& Time: Result:}

$5-4$

$4: 05 \mathrm{pm}$

$6: 58 \mathrm{pm}$

$7: 49 \mathrm{pm}$

No answer

Busy signal

Conducted $40 \mathrm{~min}$ interview

$5-4$

$11: 15 \mathrm{am}$

$11: 17 \mathrm{am}$

$3: 43 \mathrm{pm}$

$5: 16 \mathrm{pm}$

$5: 17 \mathrm{pm}$

Left message, got cut off

Left message (home phone)

No answer

He returned call

Conducted $15 \mathrm{~min}$ interview

$5-4$

$11: 07 \mathrm{am}$

mid aft

Left message (home phone)

$3: 40 \mathrm{pm}$

$7: 10 \mathrm{pm}$

He called and left message

Left message (home phone)

conducted $10 \mathrm{~min}$ interview

$$
\begin{array}{ll}
4-27 & 8: 26 \mathrm{pm} \\
5-2 & 5: 26 \mathrm{pm} \\
5-3 & 9: 20 \mathrm{pm} \\
& 3: 50 \mathrm{pm} \\
5-4 & 10: 31 \mathrm{am} \\
& 4: 30 \mathrm{pm} \\
& 4: 32 \mathrm{pm}
\end{array}
$$

Left message (home phone)

Left message (home phone)

He called and left message

Left message (church ph)

Left message (home phone)

He called collect

Conducted $11 \mathrm{~min}$ interview

No answer

No answer

No answer

No answer

5-5 7:06am

$5-4$

$4: 01 \mathrm{pm}$

$7: 00 \mathrm{pm}$

Left message

Left message

$7: 43 \mathrm{pm}$

Daughter returned call-He's in Bulgaria

No AIM calls in 5 years-declined interview

Call after 6:00pm at home Call 5-5 at 6:00am

Conducted $10 \mathrm{~min}$ interview

5-5 6:05am

Left message (home phone)

Conducted 11 min interview 
Person Number:

77.

78 .

79.

80

81.

82

83.
Date \& Time: Result:

$$
\begin{array}{ll}
4-27 & 8: 30 \mathrm{pm} \\
4-29 & 3: 20 \mathrm{pm} \\
5-3 & 3: 54 \mathrm{pm}
\end{array}
$$

No answer

No answer

Conducted $13 \mathrm{~min}$ interview

$$
\text { 4-27 8:45pm }
$$

Declined due to interview being recorded

$5-2$

$$
8: 24 \mathrm{pm}
$$

Conducted

12 min interview

$$
5-4
$$

$11: 12 \mathrm{am}$

$3: 56 \mathrm{pm}$

Left message (home phone)

$7: 30 \mathrm{pm}$

No answer

Unavailable till next week

4-27 7:50pm

5-3 4:10pm

Left message (home phone)

Left message

$5-4 \quad 10: 34$ am

Conducted 8 min interview

4-27 8:31pm

Incorrect ph number given

4-27 8:05pm

Conducted $11 \mathrm{~min}$ interview 
PHONE LOG: STAFF

Person Number:

84.

85.

86.

87.

88 .
Date \& Time: Result:

\section{$4-25$}

$4-25$

$4-27$

$4-28$

$4-29$

$8: 30$ am

am

$\mathrm{am} / \mathrm{pm}$

am

$10: 00$ am

$10: 45 \mathrm{am}$

$4-25$

$4-25$

$4: 25$

$8: 30$ am

am

$11: 05 \mathrm{am}$

$4-25$

$4-25$

$4-27$

$4-28$

$8: 30 a m$

$\mathrm{pm}$

$1: 09 \mathrm{pm}$

$1: 30 \mathrm{pm}$

$1: 40 \mathrm{pm}$

$4-25 \quad 8: 30 a m$

4-28 pm

4-25 8:30am

4-25 pm

4-29 pm

4-29 pm

5-2 11:07am

$5-3 \quad 7: 45$ am

$5-3 \quad 8: 10 \mathrm{am}$

$5-4 \quad 6: 15 \mathrm{am}$

Busy

Busy Busy
Left message re: pilot

They left return message

Busy till 5:15pm

Conducted $35 \mathrm{~min}$ interview

Left message re: pilot

They left return message

Conducted $45 \mathrm{~min}$ interview

Left message re: pilot

They left return message Busy--call 4-28 at 1:30pm

Conducted $75 \mathrm{~min}$ interview

Left message re: pilot

They spoke return message

Left message re: pilot

Return message: postpone due to illness

They left message

Cal1 5-2 at 11:00am PDT

Conducted $55 \mathrm{~min}$ interview

Call 5-3 at 7:45am PDT

Requested 15-20 min delay

Conducted $80 \mathrm{~min}$ interview

Call 5-4 at 6:15am PDT

Conducted $65 \mathrm{~min}$ interview 


\section{APPENDIX F}

ADVENTIST INFORMATION SERVICE/MINISTRY:

EXAMPLES OF EARLY. LETTERHEADS

1. Adventist Information Service Letterhead

2. Adventist Information Ministry Letterhead 


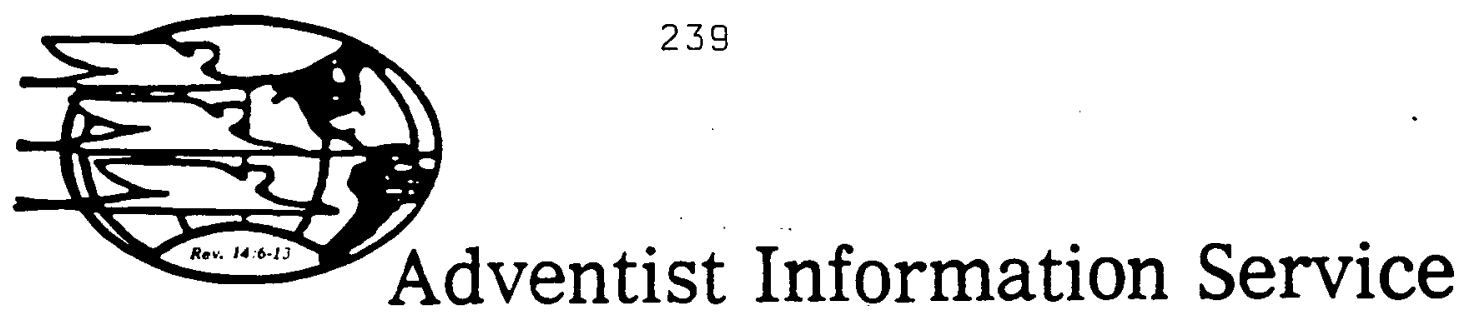

Berrien Springs, Michigan 49104

March 18, 1983

Dear Sir:

Enclosed, please find the most recent interest cards which have been generated from the Breath of Life telecast.

I would like to take this opportunity to clarify a few aspects in regard to the use of the interest cards. These cards stem from individuals who merely phoned or wrote to the program at least once. It does not mean that these persons are prime interests: they are potential interests. Top priority interests are handled by AIM in a different manner. We call the local pastor direct, within three days of the original call, and inform him of the interest. We maintain communication with the field to monitor the progress of an interest. When difficulties are encountered, and a busy pastor is unable to process the contact, we refer the name to an active layman.

If you have any questions concerning the information printed on these interest cards, or if there is any other way in which we can be of service to you, please feel free to contact us.

May the Lord continue to richly bless you as you direct the work in His vineyard.

Sincerely yours,

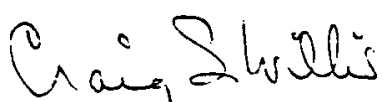

Craig S. Wiltis,

Chaplain Supervisor 


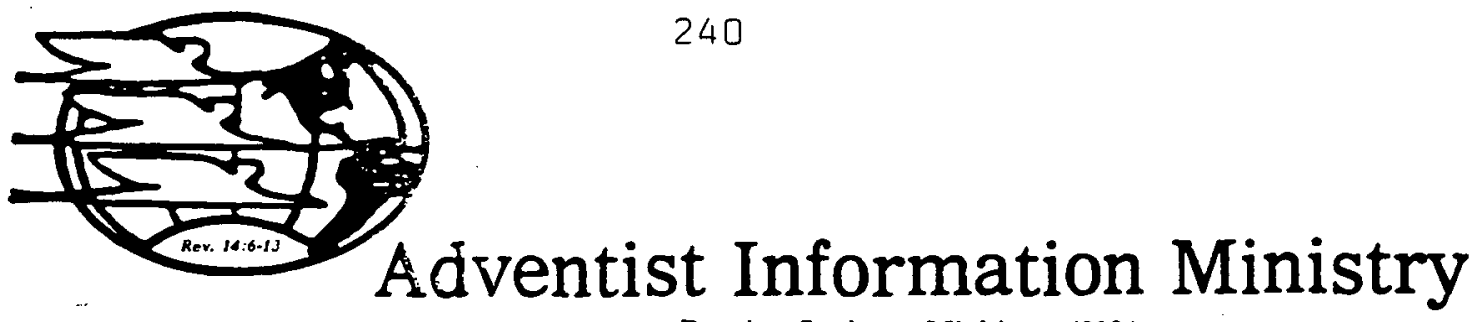

Berrien Springs, Michigan 49104

Narch 31,1983

Elder Royce C. Williars

It Is written

7.100 Rancho Conejo BIvd.

Newbury Park, CA 9 , 320

Dear EIder WiIIians:

I have enclosed the statistics fror. last Sunday's battery of phone calls. You will note that all of the swaller stations (nori-TBS) seer to be drawing about the sarre size audience response. TES out of Atlanta is quite sporadic and unpredictable in the response we obtain. It was a good prograr last Sunday, but the offer had been made a number of times. Fence, it would account for a low response.

You will also find enclosed a set of $4 \times 6$ cards. I have divided ther. into the following categories: i) Contribution requests for an enveiope; 2) Requests for back orders; 3) Multiple copies of books, some of which are back orders in multiples; and 4) Former requests never received.

We are still receiving requests about EIIen White, as you will observe in the back orcer. That progran was a very positive force in helping correct the present situation. We have received several requests from persons who were so impressed by the prograr that they wanted to know what denorination sponsored it, and how to get in contact with a local church. Cne ran last Suncay, a Mr. Earl waiters in San Diego, wanted to know how a person joins the Adventist Church. These particular type calls are followed up immediately with a call to the local field. We will keep you posted of the progress of such persons.

Thank you again for your wonderful ministry at It Is Written. May the Lord continue to bless you and Elder Vanderan with continued strength and wisdor. to guide the work.

Sincerely,

Craig S. Willis

Phone 800 253-7077

Michigan $616 \quad 471-3522$

Alaska and Hawaii 800 253-3002 


\section{APPENDIX G}

THE AIM CHAPLAIN'S DISCLAIMER STATEMENT 
Adventist Information Ministry

CONFERRAL REPORT

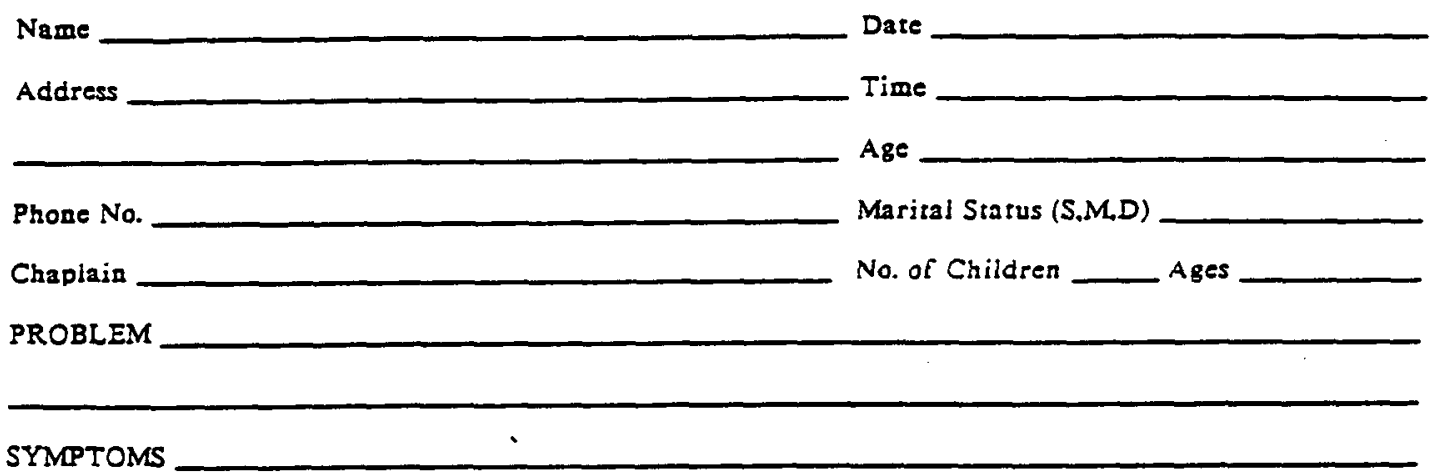

- DISCLAIMER: "Let me clarify that I am a minister, and not a trained psychologist or counselor. I will be happy to give you a Christian perspective on this matter, if you want to proceed on that basis."

(I have read the disclaimer to the caller. Yes

No

OPTIONS

ADVANTAGES

DECISIONS/GOALS

Shor: Term

CHAPLAIN'S ASSESSMENT

SUMMMARIZED: RECORDED: Y
DISADVANTAGES

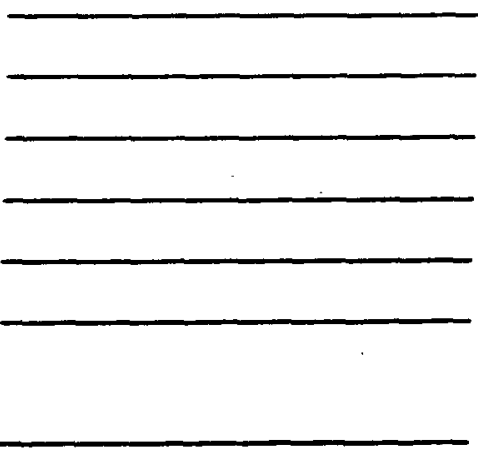

\section{Long Term}

C:|WPSI|FOLIOW/CONFERALRPT 8/91 


\section{APPENDIX H}

\section{AIM EXECUTIVE STEERING COMMITTEE MEETING ATTENDANCE}

1. AIM Executive Steering Committee Meeting Attendance: Meeting Attendance 1984-1993

2. AIM Executive steering Committee Meeting Attendance: Number of Meetings Attended $1984-1993$ 


\section{AIM EXECUTIVE STEERING COMMITTEE: MEETING ATTENDANCE 1984-1993}

\begin{tabular}{|c|c|c|c|}
\hline $\begin{array}{l}\text { MEETING A (12-13-84) } \\
\text { Andrews University } \\
\text { R.L.Dale-Chairman } \\
\text { R.E.Klimes-Secretary } \\
\text { M.T.Bascom } \\
\text { D.R.Christman } \\
\text { D.D.Cummings } \\
\text { R.D.Moon } \\
\text { M.M.Murray } \\
\text { O.A.Troy }\end{array}$ & $\begin{array}{l}\text { MEETING B (08-12-86) } \\
\text { Andrews University } \\
\text { Robert Dale-Chairman } \\
\text { Robert Moon-Secretary } \\
\text { Thomas Ashlock } \\
\text { Phillip Follett } \\
\text { Gerhard Hasel } \\
\text { Thomas Mostert } \\
\text { Owen Troy } \\
\text { Gene Hamlin, Guest } \\
\text { Craig Willis, Guest and } \\
\text { Recording Secretary }\end{array}$ & $\begin{array}{l}\text { MEETING C (02-23-88) } \\
\text { Location Unknown } \\
\text { Gary Patterson-Chairman } \\
\text { Robert Moon-Secretary } \\
\text { George Crumley } \\
\text { Robert Dale } \\
\text { Owen Troy } \\
\text { Craig Willis, Guest and } \\
\text { Recording Secretary }\end{array}$ & $\begin{array}{l}\text { MEETING D }(05-5-88) \\
\text { Thousand Oaks,CA } \\
\text { Gary Patterson, Chairman } \\
\text { Owen Troy, Vice Chairman } \\
\text { Robert Moon, Secretary } \\
\text { C.E.Bradford } \\
\text { G.H.Crumley } \\
\text { R.L.Dale } \\
\text { M.C.Van Putten }\end{array}$ \\
\hline $\begin{array}{l}\text { MEETING E }(07-22-88) \\
\text { Andrews University } \\
\text { Gary Patterson, Chairman } \\
\text { Owen Troy, Vice Chairman } \\
\text { Robert Moon, Secretary } \\
\text { Warren Banfield } \\
\text { George Crumley } \\
\text { Robert Dale }\end{array}$ & $\begin{array}{l}\text { MEETING F (08-16-88) } \\
\text { Location Unknown } \\
\text { Gary Patterson, Chairman } \\
\text { Owen Troy, Vice Chairman } \\
\text { Robert Moon, Secretary } \\
\text { George Crumley } \\
\text { Robert Dale } \\
\text { Tom Gilbert } \\
\text { Robert Jacobs } \\
\text { Robert Woodfork }\end{array}$ & $\begin{array}{l}\text { MEETING G (02-27-89) } \\
\text { Location Unknown } \\
\text { Gary Patterson, Chairman } \\
\text { Robert Moon, Secretary } \\
\text { George Crumley } \\
\text { Robert Dale } \\
\text { M.C. Van Putten }\end{array}$ & $\begin{array}{l}\text { MEETING H (07-31-89) } \\
\text { Location Unknown } \\
\text { Gary Patterson, Chairman } \\
\text { Robert Moon, Secretary } \\
\text { George Crumley } \\
\text { Robert Dale } \\
\text { M.C. Van Putten }\end{array}$ \\
\hline $\begin{array}{l}\text { MEETING I (10-05-89) } \\
\text { Location Unknown } \\
\text { Gary Patterson, Chairman } \\
\text { Robert Moon, Secretary } \\
\text { George Crumley } \\
\text { Robert Dale } \\
\text { Owen Troy } \\
\text { M.C. Van Putten }\end{array}$ & $\begin{array}{l}\text { MEETING J }(2-27-90) \\
\text { Location Unknown } \\
\text { Gary Patterson, Chairman } \\
\text { Robert Moon, Secretary } \\
\text { George Crumley } \\
\text { Robert Dale } \\
\text { Craig Willis, Guest }\end{array}$ & $\begin{array}{l}\text { MEETING K (2-4-91) } \\
\text { Location Unknown } \\
\text { Gary Patterson, Chairman } \\
\text { Robert Moon, Secretary } \\
\text { Glenn Aufderhar } \\
\text { George Crumley } \\
\text { Robert Dale } \\
\text { Phil Follett }\end{array}$ & $\begin{array}{l}\text { MEETING L (11-5-91) } \\
\text { Andrews University } \\
\text { Gary Patterson, Chairman } \\
\text { Robert Moon, Secretary } \\
\text { G. Crumley } \\
\text { R.L. Dale } \\
\text { R. Lindsey } \\
\text { J. Lynn Martell } \\
\text { Owen Troy } \\
\text { M. Vasquez }\end{array}$ \\
\hline $\begin{array}{l}\text { MEETING M (7-23-92 am) } \\
\text { Lake Union Rotunda } \\
\text { Gary Patterson, Chairman } \\
\text { Robert Moon, Secretary } \\
\text { Robert Dale } \\
\text { Phil Follett } \\
\text { Owen Troy } \\
\text { John Hood, Guest } \\
\text { Craig Willis, Guest }\end{array}$ & $\begin{array}{l}\text { MEETING N (7-23-92 pm) } \\
\text { (Mtg con't. at 1:30PM) } \\
\text { Additional Guests: } \\
\text { Russell Burrill } \\
\text { Mrs. Russel Burrill } \\
\text { Don James } \\
\text { Doug Kilcher } \\
\text { Rebecca Lofthouse } \\
\text { Ben Schoun } \\
\text { Werner Vyhmeister }\end{array}$ & $\begin{array}{l}\text { MEETING O (10-7-92) } \\
\text { Location Unknown } \\
\text { Gary Patterson, Chair } \\
\text { Robert Moon, Secretary } \\
\text { Glenn Aufderhar } \\
\text { J. Lynn Martell } \\
\text { Owen Troy } \\
\text { Werner Vyhmeister }\end{array}$ & $\begin{array}{l}\text { MEETING P (2-1-92) } \\
\text { Shell Beach, CA } \\
\text { Gary Patterson, Chairman } \\
\text { Robert Moon, Secretary } \\
\text { Glenn Aufderhar } \\
\text { Robert Dale } \\
\text { Ron Lindsey } \\
\text { Owen Troy } \\
\text { Meade Van Putten }\end{array}$ \\
\hline $\begin{array}{l}\text { MEETING Q (2-23-93) } \\
\text { NADEI Rm. Andrews Univ } \\
\text { Gary Patterson, Chairman } \\
\text { Robert Moon, Secretary } \\
\text { Robert Dale } \\
\text { Russell Burrill-Guest } \\
\text { Doug Kilcher-Guest }\end{array}$ & & & \\
\hline
\end{tabular}




\begin{tabular}{|c|c|c|c|c|c|c|c|c|c|c|c|c|c|c|c|c|c|}
\hline & & & & & & & TAl & LE 1 & & & & & & & & & \\
\hline Meeting $\# \rightarrow$ & $\mathrm{A}$ & B & $\mathrm{C}$ & $\mathrm{D}$ & $\mathrm{E}$ & $\mathrm{F}$ & $\mathrm{G}$ & $\mathbf{H}$ & 1 & $J$ & $\underline{\mathrm{K}}$ & $\mathrm{L}$ & $\mathrm{MN}$ & 0 & $\mathbf{P}$ & $Q$ & Tousl \\
\hline Ashlock & & $\mathrm{M}$ & & & & & & & & & & & & & & & 1 \\
\hline Aufderhar & & & & & & & & & & & $\mathrm{M}$ & & & $\mathrm{M}$ & $\mathrm{M}$ & & 3 \\
\hline Banfield & & & & . & $\mathrm{M}$ & & & & & & & & & & & & 1 \\
\hline Bascom & $\mathrm{M}$ & & & & & & & & & & & & & & & & 1 \\
\hline Bradford & & & & $\mathbf{M}$ & & & & & & & & & & & & & 1 \\
\hline Mr/Mrs Burrill & & & & & & & & & & & & & GG & & & G & $2 / 1$ \\
\hline Christman & $\mathrm{M}$ & & & & & & & & & & & & & & & & 1 \\
\hline Crumley & & & $\mathrm{M}$ & $\mathrm{M}$ & $\mathrm{M}$ & $\mathrm{M}$ & $\mathbf{M}$ & $\mathrm{M}$ & $\mathrm{M}$ & $\mathrm{M}$ & M & $\mathrm{M}$ & & & & & 10 \\
\hline Cummings & $\mathbf{M}$ & & & & & & & & & & & & & & & & 1 \\
\hline Dale & $\mathrm{CH}$ & $\mathrm{CH}$ & $\mathrm{M}$ & $\mathrm{M}$ & $\mathrm{M}$ & $\mathrm{M}$ & $\mathrm{M}$ & $\mathrm{M}$ & $\mathrm{M}$ & $\mathrm{M}$ & $\mathrm{M}$ & $\mathrm{M}$ & $\mathrm{M}$ & & $\mathbf{M}$ & $M$ & 15 \\
\hline Follett & & $\mathrm{M}$ & & & & & & & & & $\mathrm{M}$ & & $\mathrm{M}$ & & & & 3 \\
\hline Gilbert & & & & ' & & $\mathrm{M}$ & & & & & & & & & & & 1 \\
\hline Hamlin & & $\mathrm{G}$ & & & & & & & & & & & & & & & 1 \\
\hline Hasel & & $\mathrm{M}$ & & & & & & & & & & & & & & & 1 \\
\hline Hood & & & & & & & & & & & & & G & & & & 1 \\
\hline Jacobs & & & & & & $\mathbf{M}$ & & & & & & & & & & & 1 \\
\hline James & & & & & & & & & & & & & $\mathrm{G}$ & & & & 1 \\
\hline Kilcher & & & & & & & & & & & & & $\mathrm{G}$ & & & $\mathrm{G}$ & 2 \\
\hline Klimes & $\mathrm{SE}$ & & & & & & & & & & & & & & & & 1 \\
\hline Lindsey & & & & & & & & & & & & $\mathrm{M}$ & & & $\mathrm{M}$ & & 2 \\
\hline Lofthouse & & & & & & & & & & & & & $\mathrm{G}$ & & & & 1 \\
\hline Martell & & & & & & & & & & & & M & & $\mathrm{M}$ & & & 2 \\
\hline Moon & $\mathrm{M}$ & $\mathrm{SE}$ & $\mathrm{SE}$ & $\mathrm{SE}$ & SE & SE & $\mathrm{SE}$ & SE & $\mathrm{SE}$ & SE & SE & SE & SE & $\mathrm{SE}$ & SE & $\mathrm{SE}$ & 16 \\
\hline Mostert & & $\mathrm{M}$ & & & & & & & & & & & & & & & 1 \\
\hline Murray & $\mathrm{M}$ & & & & & & & & & & & & & & & & 1 \\
\hline Patterson & & & $\mathrm{CH}$ & $\mathrm{CH}$ & $\mathrm{CH}$ & $\mathrm{CH}$ & $\mathrm{CH}$ & $\mathrm{CH}$ & $\mathrm{CH}$ & $\mathrm{CH}$ & $\mathrm{CH}$ & $\mathrm{CH}$ & $\mathrm{CH}$ & $\mathrm{CH}$ & $\mathrm{CH}$ & $\mathrm{CH}$ & 14 \\
\hline Schoun & & & & & & & & & & & & & $\mathrm{G}$ & & & & 1 \\
\hline Troy & $\mathrm{M}$ & $\mathrm{M}$ & $\mathrm{M}$ & $\mathrm{VC}$ & $\mathrm{VC}$ & vC & & & $\mathrm{M}$ & & & $\mathbf{M}$ & $\mathrm{M}$ & $\mathrm{M}$ & $\mathrm{M}$ & & 11 \\
\hline VanPutten & & & & $\mathrm{M}$ & & & $\mathrm{M}$ & $\mathrm{M}$ & $\mathrm{M}$ & & & & & & $\mathrm{M}$ & & 5 \\
\hline Vasquez & & & & & & & & & & & & $M$ & & & & & 1 \\
\hline Vyhmeister & & & & & & & & & & & & & G & $\mathrm{M}$ & & & 2 \\
\hline Willis & & G & $\mathrm{G}$ & & & & & & & $\mathrm{G}$ & & & $\mathrm{G}$ & & & & 4 \\
\hline Woodfork & & & & & & M & & & & & & & & & & & 1 \\
\hline
\end{tabular}




\section{BIBLIOGRAPHY}




\section{BIBLIOGRAPHY}

"Adventist Information Ministry Begun on Campus." Focus, Fall 1982, 2.

Andrews University Bulletin, Vols. 60-70. Berrien Springs, MI: Andrews University, 1971-1983.

"Annual Council Action on Evangelism and Finishing God's Work." Ministry, December 1976, 4.

Board of Trustees, Ellen G. White Estate. Comprehensive Index to the Writings of Ellen G. White. Boise, ID: Pacific Press Publishing, 1962.

Boyd, Gina, Harvey Brenneise, and Daniel Drazen, eds. Seventh-day Adventist Periodical Index. 13 vols. Berrien Springs, MI: Andrews University Press, 19811993.

Bradford, Charles. "The High Cost of Evangelism." Ministry, June 1981, 11.

Cash, William. "The Computer Comes to Campus." Focus, Spring 1986, 14.

Cummings Jr., Des. "The Church's Agenda for the 80 's." Focus, Spring 1981, 26.

Cummings Jr., Des, Robert Moon, and Lowell Witz. "Preliminary Proposal to It Is Written By Andrews University to Provide Listener Request Processing, Interest Follow-Up, and Donation Processing Services." Unpublished TMs.

Dillman, Don. Mail and Telephone Surveys: The Total Design Method. New York: John Wiley and Sons, 1978.

Dudley, Roger. "Editor's Perspective." Administry, Autumn 1982,2 . 
Dudley, Roger, and Des Cummings, Jr. Adventures in Church Growth. Washington, DC: Review and Herald Publishing, 1983 .

Erdos, Paul. Professional Mail Surveys. Malabar, FL: Robert E. Krieger Publishing Company, 1983.

Fink, Arlene, and Jacqueline Kosecoff. How To Conduct Surveys: A Step-by-step Guide. Beverly Hills, CA: Sage Publications, 1985 .

Gill, Linda. "The Phones Keep Ringing at the Adventist Information Ministry." Lake Union Herald, October $26,1982,7$.

Groves, Robert, and Robert Kahn. Surveys by Telephone: A National Comparison with Personal Interviews. New York: Academic Press, 1979.

"Highlights of the Andrews University 800 Number: Interest Identification and Follow-Up system." Unpublished TMS, estimated 1979 to early 1980.

Holmes, C. Raymond. "Guidelines for the Doctor of Ministry Project, Project Proposal, and Project Report." CHMN 790 Project Seminar Class Handout, Berrien Springs, MI, SDA Theological Seminary, Andrews University, July 1993 .

"Institute Created to Promote Church Growth." Focus, Summer 1980,5 .

Knott, Ronald. "A New Telephone Ministry." Lake Union Herald, May 25, 1982, 4.

"Information Ministry Is Established at Andrews." Adventist Review, November 25, 1982, 12 .

"A Telephone Ministry for the Nation." Lake Union Herald, July 19, 1983, 6 .

McQuistan, J. Roger. Telephone Ministry. Washington, DC: Review \& Herald Publishing, 1982.

Metcalf, Harold E. The Magic of Telephone Evangelism. Atlanta, GA: Southern Union Conference, 1967. 
Moon, Robert. "Minutes of Ad Hoc Committee on 800 System to Support Media Evangelism." Unpublished TMs, December 7, 1981.

North Jr., James J. "Chaplaincy Ministries: The Development and Implementation of a Course in Specialized Ministries as Vehicles for Seventh-day Adventist SelfUnderstanding and Expression of Mission." D.Min. project, Andrews University, 1988.

Quigley, W. B. "One Thousand Days of Reaping." Ministry, February 1982, 8 .

Seventh-day Adventists Believe: A Biblical Exposition of 27 Fundamental Doctrines. Hagerstown, MD: Ministerial Association, General Conference of Seventh-day Adventists, 1988.

Seventh-day Adventist Encyclopedia. Washington, DC: Review and Herald, 1976 ed. S.v. "Evangelism, Public."

Seventh-day Adventist Yearbook. Washington, DC: Review and Herald, 1982 .

"Stand Ye in the Ways" [Jer 6:16]. Seventh-day Adventist Bible Commentary. Edited by F. D. Nichol. Washington, DC: Review and Herald, 1976. 4:383.

Survey Research Center. Interviewer's Manual. Rev. ed. Ann Arbor, MI: Institute for Social Research, 1976.

"The Personal Touch of Adventist Information Ministry." Slide and Cassette Tape Presentation. Decatur, GA: Photo Sound International, 1987.

"The Tool of the Decade." Focus, Summer 1990, 15.

Tilstra, Doug. "800 Number Facilitates Follow-Up." Administry, Autumn 1982, 10.

Vyhmeister, Nancy Jean. Handbook for Research. Silang, Cavite, Republic of Philippines: Aiias Publications, 1989 .

Handbook for Research. Berrien Springs, MI: Seventh-day Adventist Theological Seminary, 1998. 
White, Ellen G. Adventist Home. Nashville, TN: Southern Publishing Association, 1952 .

- Desire of Ages. Mountain View, CA: Pacific Press Publishing, 1898.

- Education. Mountain View, CA: Pacific Press Publishing, 1903 . 1946 .

Evangelism. Washington, DC: Review and Herald, - Life Sketches. Mountain View, CA: Pacific

Press Publishing, 1915.

- Testimonies for the Church, 9 vols. Mountain $\overline{V i e w, ~ C A}$ : Pacific Press Publishing, 1948.

Willis, Craig. "Adventist Information Ministry: The Denomination's Resource Center for Data Processing and Evangelism." Administry, Autumn 1983, 4. August 1991 .

Wilson, Neal. "Our First Business." Ministry, April 1982, 2 .

Witz, Lowell D. "A.I.M. History," letter to the editor. Focus, Summer 1993, 2 . 
VITA 


\section{VITA: GREGORY A. HARPER}

Ministerial/Educational Experience:

Dates:

Pastor, Gerhart Memorial Seventh-day Adventist Church, Cookeville, TN

$10 / 94$

Senior Chaplain, Adventist Information Ministry, Berrien Springs, MI

$3 / 92-9 / 94$

Graduate Student, Andrews University, Berrien Springs, MI

$6 / 90-9 / 94$

Pastor, Paradise Las Vegas and Boulder City SDA Churches, NV

$2 / 88-5 / 90$

Clinical Pastoral Education, Loma Linda University Medical Center, CA

Fall/87

Ordained, Lake Tahoe Campmeeting, Nevada-Utah Conference

$8 / 87$

Pastor, Monument Valley SDA Church, UT

$1 / 85-1 / 88$

Assistant Manager, Sierra Glen Ranch, Sonora, CA

$6 / 84-12 / 84$

Pastor, Boulder City, and Associate Pastor, Las Vegas, SDA Churches, NV

$4 / 82-5 / 84$

Intern Pastor, Susanville SDA Church and Westwood Company, CA

$6 / 81-3 / 82$

Undergraduate Student, Weimar College, Weimar, CA

$9 / 78-6 / 81$

University/College Degrees Received:

Date:

Doctor of Ministry, Andrews University Theological Seminary, Berrien Springs, MI

Master of Divinity, Andrews University Theological Seminary, Berrien Springs, MI

$6 / 92$

Bachelor of Science in Metropolitan Ministry, Weimar College, Weimar, CA

$6 / 81$ 